\title{
WestVirginiaUniversity
}

THE RESEARCH REPOSITORY @ WVU

Graduate Theses, Dissertations, and Problem Reports

2019

\section{The Magic Flute: Modern Light on a Classic Opera}

Justin E H Burns

West Virginia University, jeb0043@mix.wvu.edu

Follow this and additional works at: https://researchrepository.wvu.edu/etd

Part of the Theatre and Performance Studies Commons

\section{Recommended Citation}

Burns, Justin E H, "The Magic Flute: Modern Light on a Classic Opera" (2019). Graduate Theses, Dissertations, and Problem Reports. 3868.

https://researchrepository.wvu.edu/etd/3868

This Thesis is protected by copyright and/or related rights. It has been brought to you by the The Research Repository @ WVU with permission from the rights-holder(s). You are free to use this Thesis in any way that is permitted by the copyright and related rights legislation that applies to your use. For other uses you must obtain permission from the rights-holder(s) directly, unless additional rights are indicated by a Creative Commons license in the record and/ or on the work itself. This Thesis has been accepted for inclusion in WVU Graduate Theses, Dissertations, and Problem Reports collection by an authorized administrator of The Research Repository @ WVU. For more information, please contact researchrepository@mail.wvu.edu. 
The Magic Flute: Modern Light on a Classic Opera

Justin Burns

Thesis submitted to the College of Creative Arts at West Virginia University in partial fulfillment of the requirements for the degree of

Master of Fine Arts

in

Lighting Design \& Technology

Alan McEwen, MFA, Chair

Radhica Ganapathy, PhD

Cornel Gabara, MFA

School of Theatre and Dance

Morgantown, West Virginia 2019

Keywords: Lighting Design, The Magic Flute, LEDs, Theatre Design

Copyright 2019 Justin Burns 


\title{
ABSTRACT \\ The Magic Flute: Modern Light on a Classic Opera
}

\author{
Justin Burns
}

Mozart's The Magic Flute is a classic opera, showcasing powerful visual moments and well-known songs. This particular production's lighting design approach consisted of modern design ideas and aesthetics, while remaining true to the classic idea of 2 forces working against one another. Focusing on the major themes in The Magic Flute, the lighting design reinforces the feelings of fear, despair, hope and ultimately enlightenment. This paper describes the process and execution of how the lighting design achieved these goals. 


\section{Table of Contents}

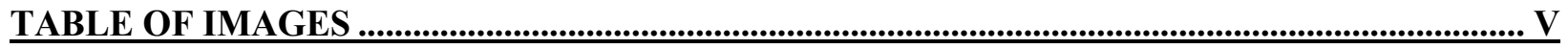

INTRODUCTION

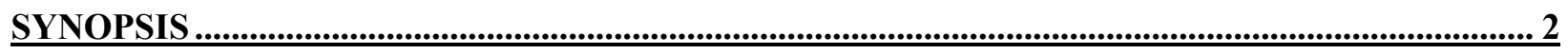

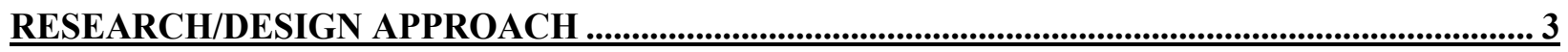

FREEMASONRY

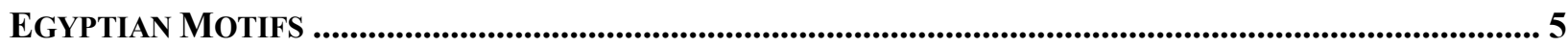

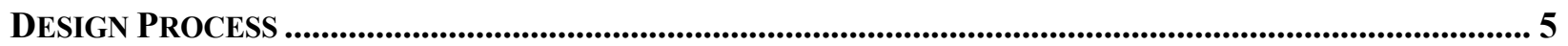

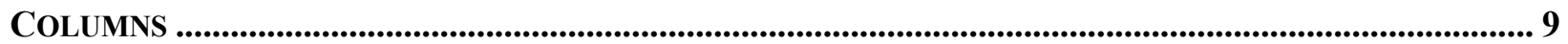

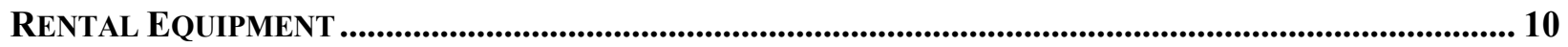

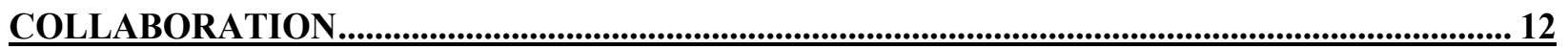

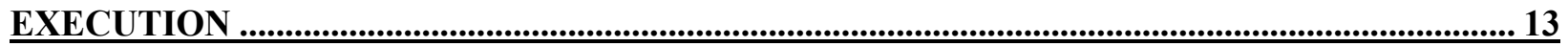

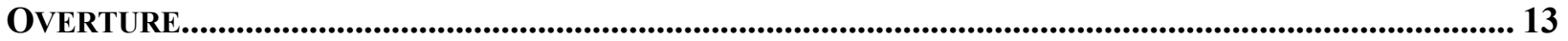

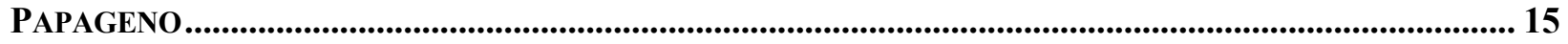

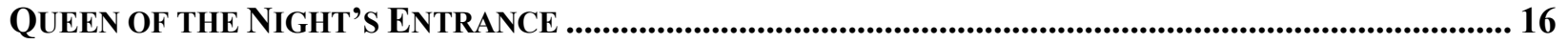

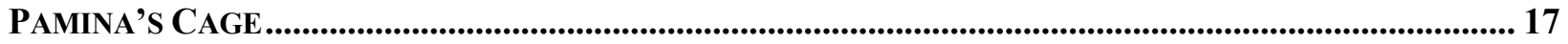

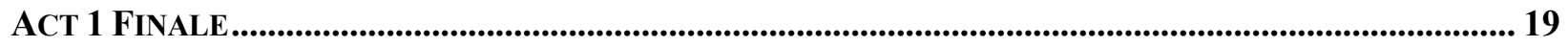

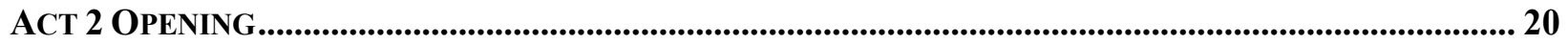

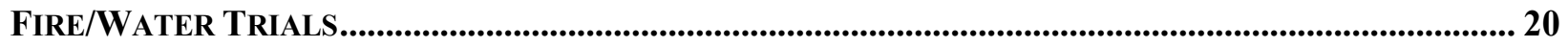

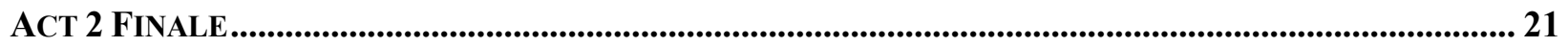

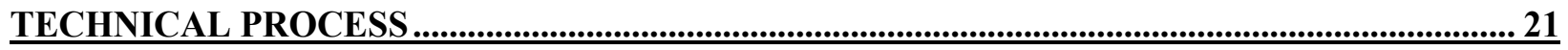

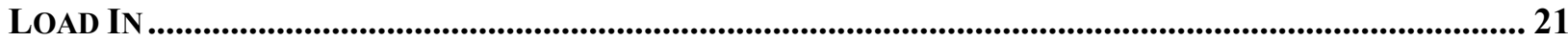

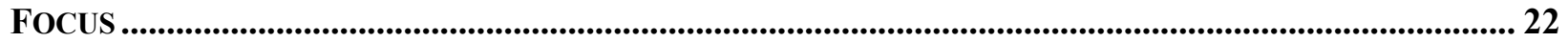

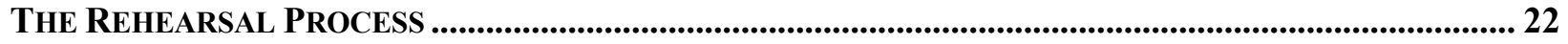

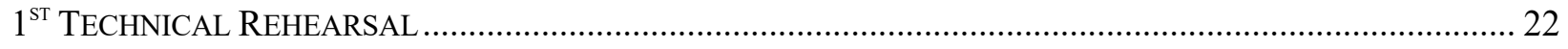

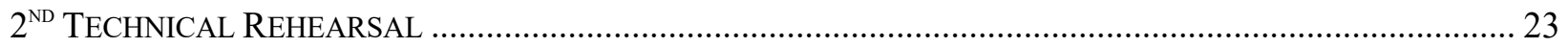

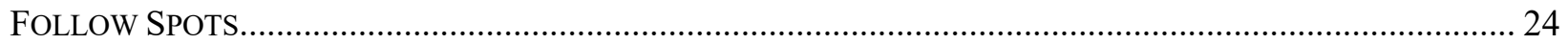

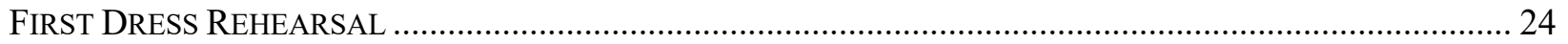

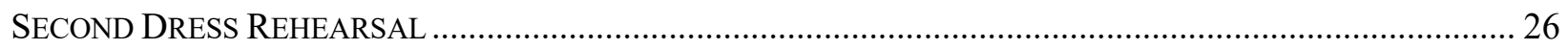

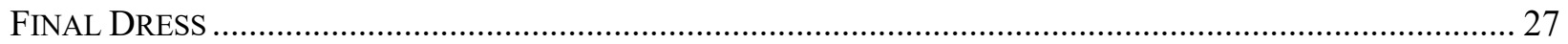

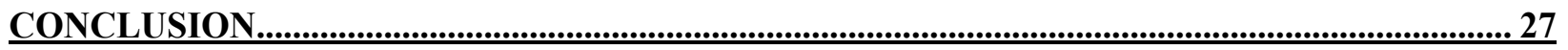

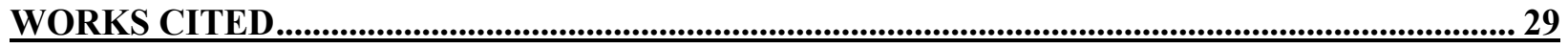




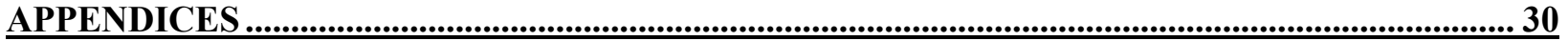

APPENDIX 1: VINCENT LIGHTING SYSTEMS RENTAL ORDER................................................................ 30

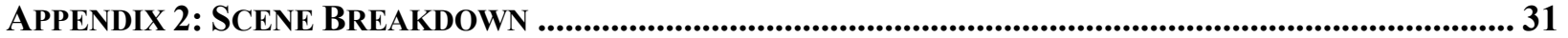

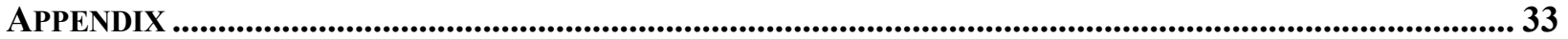

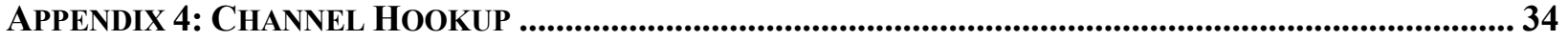

APPENDIX 5: CUE SHEET................................................................................................................................5 54

APPENDIX 6: FINAL LIGHTING BUDGET .................................................................................................... 67 


\section{Table of Images}

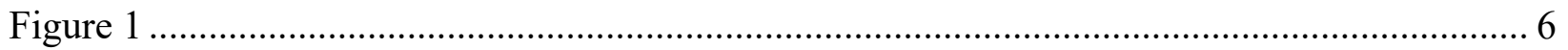

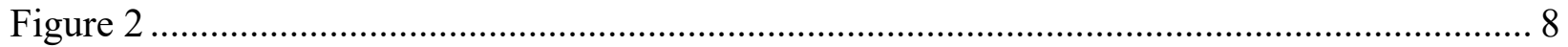

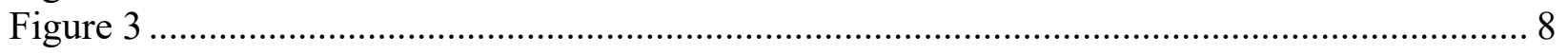

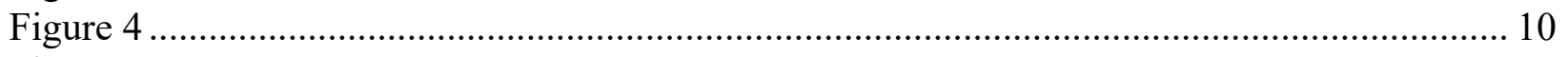

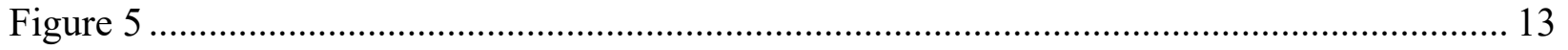

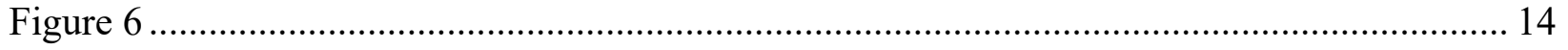

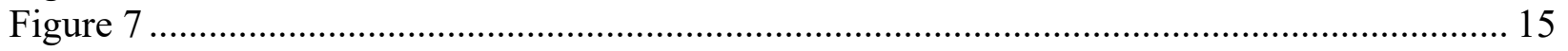

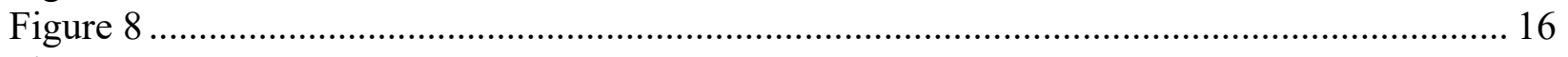

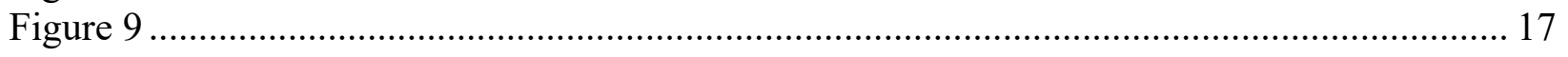

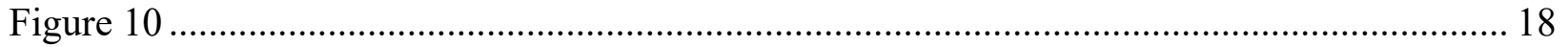

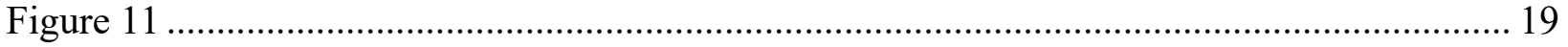

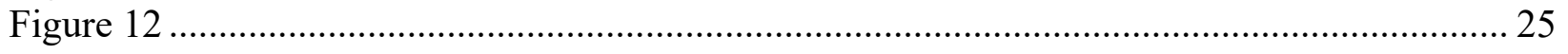

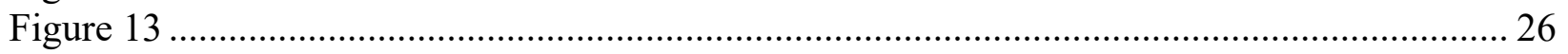




\section{Introduction}

The Magic Flute is often called one of Mozart's greatest works, and for good reason. It contains some very well-known arias and captures the struggle to reach higher wisdom/knowledge. Put in the context of today, the opera serves as a reminder of the classic themes of good versus evil, choosing enlightenment over ignorance, and the role Freemasonry had in the period this opera was written.

This production had the goal of enhancing the music and dialogue in the opera by providing a variety of visual elements that reinforced the plot, as well as the themes. Utilizing modern technology such as LED tape, LED and ultraviolet (UV) fixtures, projections, and high intensity LED moving lights, the overall lighting design provided a smorgasbord of possibilities to help push the production forward.

All lighting design requires close collaboration with the entire production team, and this production was no exception. I worked with the Scenic Designer, Professor Robert Klingelhoefer, on several visual elements to ensure the overall aesthetic was consistent. Collaborative elements ranged from the color and content of projections to scenic elements that incorporated lighting. Through working with the Costume Designer, Professor Mary McClung, blacklight/ultraviolet lighting moments within the show were identified early in the process. Using UV light allowed for the puppetry to fluoresce in darkly lit scenes, providing a sense of separation of the 3 spirits. Through the coordination of these design elements, the lighting design helped the Director, Associate Professor Cornel Gabara, stage the show in a way that ensured the action kept flowing, and that the audience was never waiting for another moment to begin. Once 
key moments such as the opening, blacklight spirit sequences, and the dramatic entrances of the Queen and Sarastro were determined, what remained was how to move between them.

\section{Synopsis}

Once the overture is completed, the action immediately moves forward as Tamino, a young prince, enters pursued by a large serpent. Tamino quickly faints, and the serpent is slain by three of the Queen's attendants, who then quickly depart. Papageno enters just as Tamino wakes up and takes credit for slaying the serpent. Papageno then plays forward his country charms with Tamino until the Queen's attendants return. A portrait of Pamina, the Queen's daughter is bestowed upon Tamino, who immediately falls in love with Pamina. Tamino vows to rescue her from Sarastro's evil clutches. Finally, the attendants gift Papageno a set of magic bells, while Tamino is given a magic flute.

As the attendants depart, the scene shifts to Pamina under close guard by Monostatos, a grotesque creature under Sarastro's control. After Monostatos unsuccessfully attempts to seduce Pamina, Papageno comes in and attempts to tell her Tamino is close. Three spirits enter as the scene changes, and guide Tamino to 3 doors. After much anguish, a priest enters and reveals the entrance to the temple. As Tamino departs, Pamina and Papageno enter, chased by Monostatos. Papageno uses his magic bells for the first time and stops Monostatos in his tracks. Concluding the first act, Sarastro enters and punishes Monostatos, and frees Pamina, but tells her she cannot return to her mother, the Queen of the Night.

The second act opens with Sarastro and his priests processing in and describing the process of the ritual Tamino and Papageno must undergo. The 3 Priests and 3 Queen's attendants give advice to the pair, and the priests take the flute and bells. 
As the scene shifts, Monostatos again attempts to proposition Pamina, but is stopped by the Queen, who tells Pamina she must kill Sarastro. Again, the scene quickly shifts to Tamino and Papageno, who are undergoing the trial of silence. During this test, Papagena, disguised as an old woman, approaches Papageno, who attempts to speak to her, but the pair struggle to hear each other, and she departs. Pamina then enters, but Tamino won't acknowledge her, trying to complete his vow of silence. The heartbroken Pamina leaves, and Papageno then asks for a wife who adores him as Pamina adores Tamino.

Pamina is stopped from killing herself with her mother's dagger by the 3 spirits, who then take her to Tamino. Papageno and Tamino survive trials of Fire and Water and exit the temple safely. Papageno is then shown preparing to hang himself, when the 3 spirits convince him to play his bells instead. His playing finally brings forth Papagena, his true love. As they declare their love for one another through song, the pair describe their optimistic future hoping for a large family.

Monostatos has now plotted with the Queen to attack Sarastro and his temple, but their attack is thwarted by an earthquake. The finale ends with Sarastro and all his converts singing the praises of light over dark, and his triumph of goodness and knowledge over evil and ignorance.

\section{Research/Design Approach}

\section{Freemasonry}

The Magic Flute has been linked to freemasonry and masonic symbols since its first production in 1791 . The very printing of the first libretto was steeped in controversy as the printer Ignaz Alberti, “a member of Mozart's lodge, supplied a frontispiece engraving” that 
"includes one regular Masonic symbol, the five-pointed star" adding that the "pick and shovel in the right foreground are a Masonic square and trowel" (MacPherson 1074). The use of masonic symbols allows the freedom to incorporate such imagery into the overall aesthetic and design of the show. This early symbolism was furthered by the text itself, which locates the entirety of the $2^{\text {nd }}$ act inside a ritualistic temple, as Papageno and Tamino begin to face trials to join Sarastro's order. It is noted in MacPherson's "The Magic Flute and Freemasonry" that Tamino and Papageno's trials in this act mirror the trials Mozart himself went through while joining the order. This provides an interesting context to the choices Tamino and Papageno make. While Tamino completes these trials willingly, Papageno resists, and ultimately refuses to choose enlightenment. In an early conversation with the director, Professor Gabara, he explained how he viewed Papageno's choice not as a defeat, but as recognizing another path one may choose, with no negative connotations.

Furthermore, symbolism and scenic choices in the opera such as the "Egyptian Room" tie to common masonic designs and temple settings. These references provide ample sources for visual imagery. Despite being secretive, Freemasons documented many of their sites, and this provided a context for some of the $2^{\text {nd }}$ act scenery. While the design may draw inspiration form masonic sources, it was important that it not serve as the sole source of design ideas. MacPherson even provides the counterargument that although the text's origins as well as the libretto itself is filled with freemasonry; the overall context proves "Masonic reference works not as substance but as means to an artistic end" (MacPherson 1083). One of the justifications he provides was Europe's fascination that had begun in the late 1790's with Egyptian motifs in general. 


\section{Egyptian Motifs}

Just as the Opera was being first produced, Europe was just beginning to rediscover Egypt. The allure of using a "mysterious landscape, one that easily lent itself to imaginative speculations about the purpose of its awesome architecture, the nature of its arcane ritual ceremonies" (Muhlestein 137) simply proved too tempting for Mozart to not use in this work. Similar to freemasonry, using these foreign settings proved to capture an audience's attention. Muhlestein goes on to state that the opera "drew on the European fascination with Egypt and contributed to it" (Muhlestein 145). Using this viewpoint allows more freedom to explore the opera more broadly. It becomes just as effective to use more abstract elements when considering the intent behind using Egyptian motifs. Given that the entire $2^{\text {nd }}$ act takes place in Egyptian influenced settings however, it is easy to find references that share common Egyptian motifs. Common images include the pyramids, columns and obelisks, references to the sun, gods Isis and Osiris, and more. Some of these were drawn out through the costume design, while a majority of these images were implemented through the scenic design and projected content. I used the Egyptian motifs more abstractly. Using the symbolism as a basis for finding other images for lighting helped shape the lighting of the stage in a larger sense. I used lighting reference images that evoked the sharp angles of the pyramids and tried to align the lighting with the grand scale of the architecture. It also was useful to explore the aesthetics of Egyptian columns, which served as a starting point to research other structures/designs that could be useful for our production.

\section{Design Process}


The research process for this production began in July of 2018. The first draft of scenic renderings was sent by email and contained many of the concepts ultimately presented in the final version.

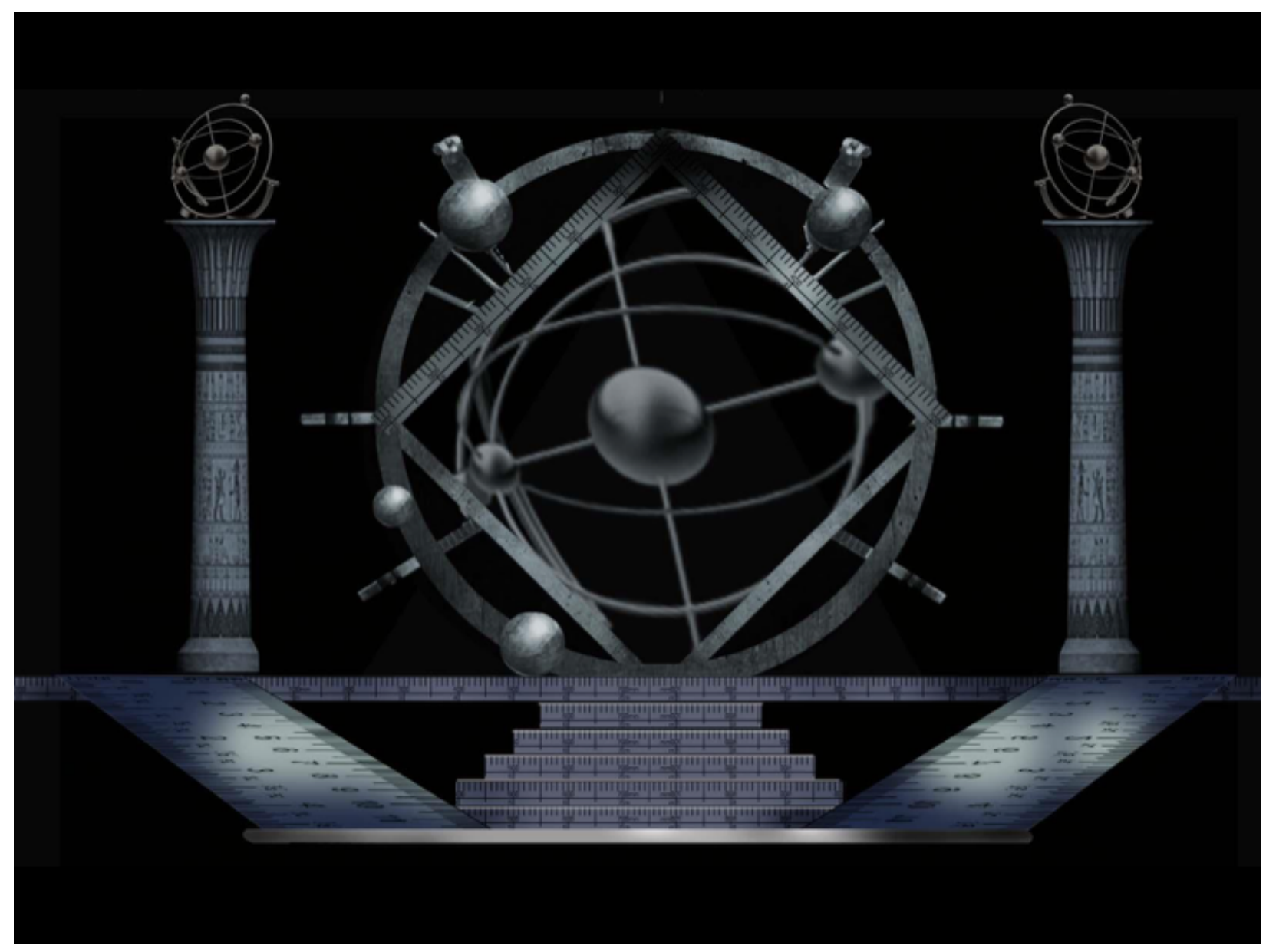

Figure 1

The set (Figure 1) used a large projection screen in the back, and a platform that covered the width of the stage. Other major elements included rocks for the opening scene, as well as a frame that closed in the projection screen into a diamond shape. 3 doors also flew in for the temple entrance in the first act, and 2 columns were on the platform on either side. The costume 
designer began to explore the idea of using puppetry for the 3 spirits, and the possibility of a large multi person serpent puppet for the overture/opening. Thematically, the design team was exploring motifs from Egyptian, $18^{\text {th }}$ century and classical architecture, steampunk, and "Marvel comics". These ideas came about from the origins of the opera, which was steeped in Freemasonry, as well as the content, which drew upon Egyptian imagery.

Although much of the initial research was more traditional, based on the masonic and Egyptian images referenced in the opera, it was still a goal to use a modern aesthetic for the production. In keeping with this goal, ideas such as "marvel comics" were considered, mostly from a costuming angle. Little changed from these initial ideas until our first design meeting in August, when several components were explored in detail.

Once everyone was in the same room, design themes were whittled down to a tighter grouping, fearing that too many different styles/design ideas would muddy the production. This was when color was discussed for the first time. To incorporate visual continuity, several 
characters had colors tied to them. The Queen of the Night was tied to a blood red moon (Figure

2). Sarastro would be represented by the embodiment of sunlight (Figure 3).

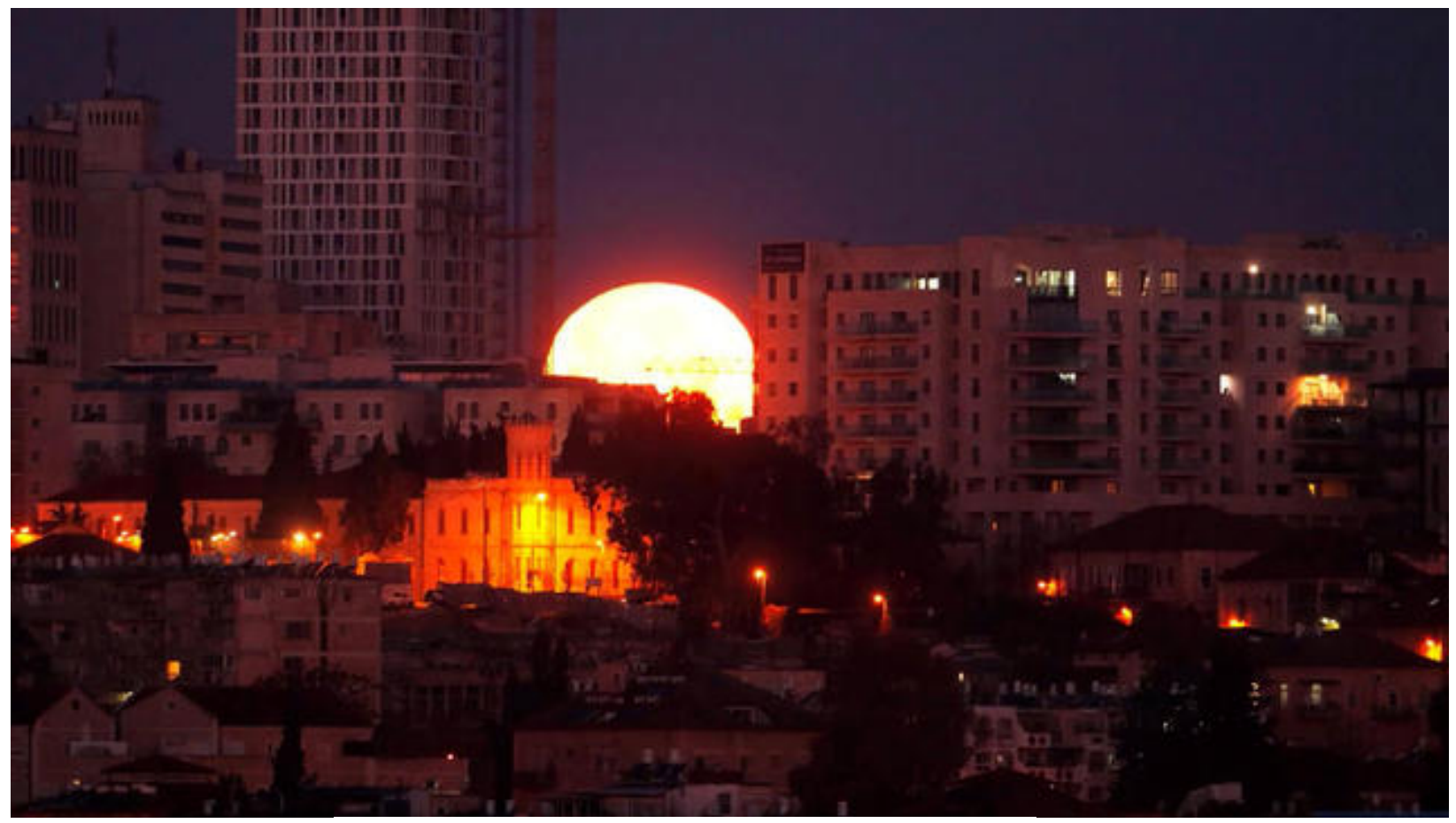

Figure 2

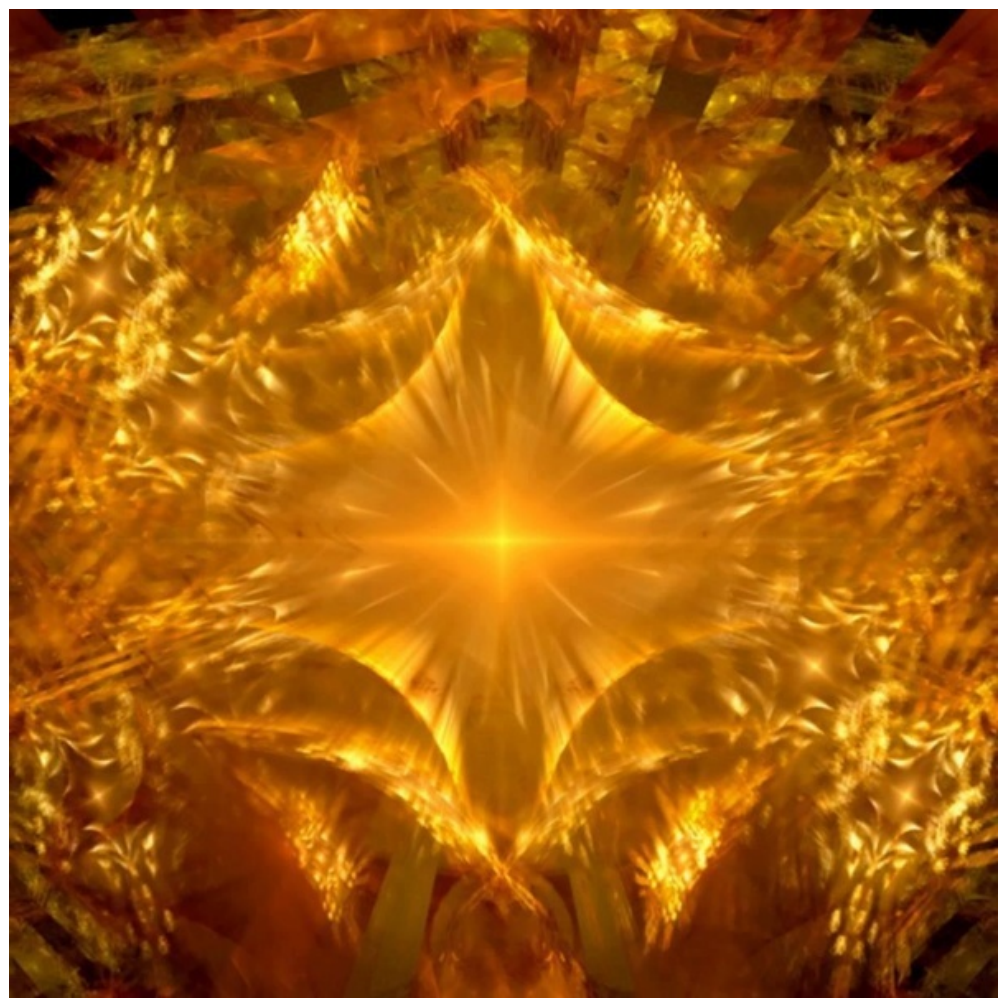

Figure 3 
These color schemes carried through the projections, lighting, and costume designs for the entire show. By contrasting these 2 characters, the entire production was divided as to whether a character or scene lived in the Queen's or Sarastro's worlds. Characters like the Queen's attendants always brought the queen's lighting with them, but less intensely than when the Queen herself was onstage.

Other characters were then fit into this paradigm. Touches of the queen's lighting would follow Pamina throughout the show. The young prince Tamino remained frigid and cold, since his opening entrance is fraught with fear. Papageno, as an independent character, relied on a country charm, and his good-natured take on life brought warmth with him as he entered the stage. Once characters had colors and design ideas tied to them, larger aesthetic elements then began to fall into place.

\section{Columns}

The 2 columns, which started as a static item in the design, became a major lighting design element once I presented an image of an art installation of columns (Figure 4) that used a variety of exterior designs to create different textures when lit from within. The scenic designer latched onto this image and began to incorporate different textures and translucent paint treatments into his design. This decision allowed for different colors to shine from within the column, providing a wide variety of dynamic visual looks with only 2 scenic units. 


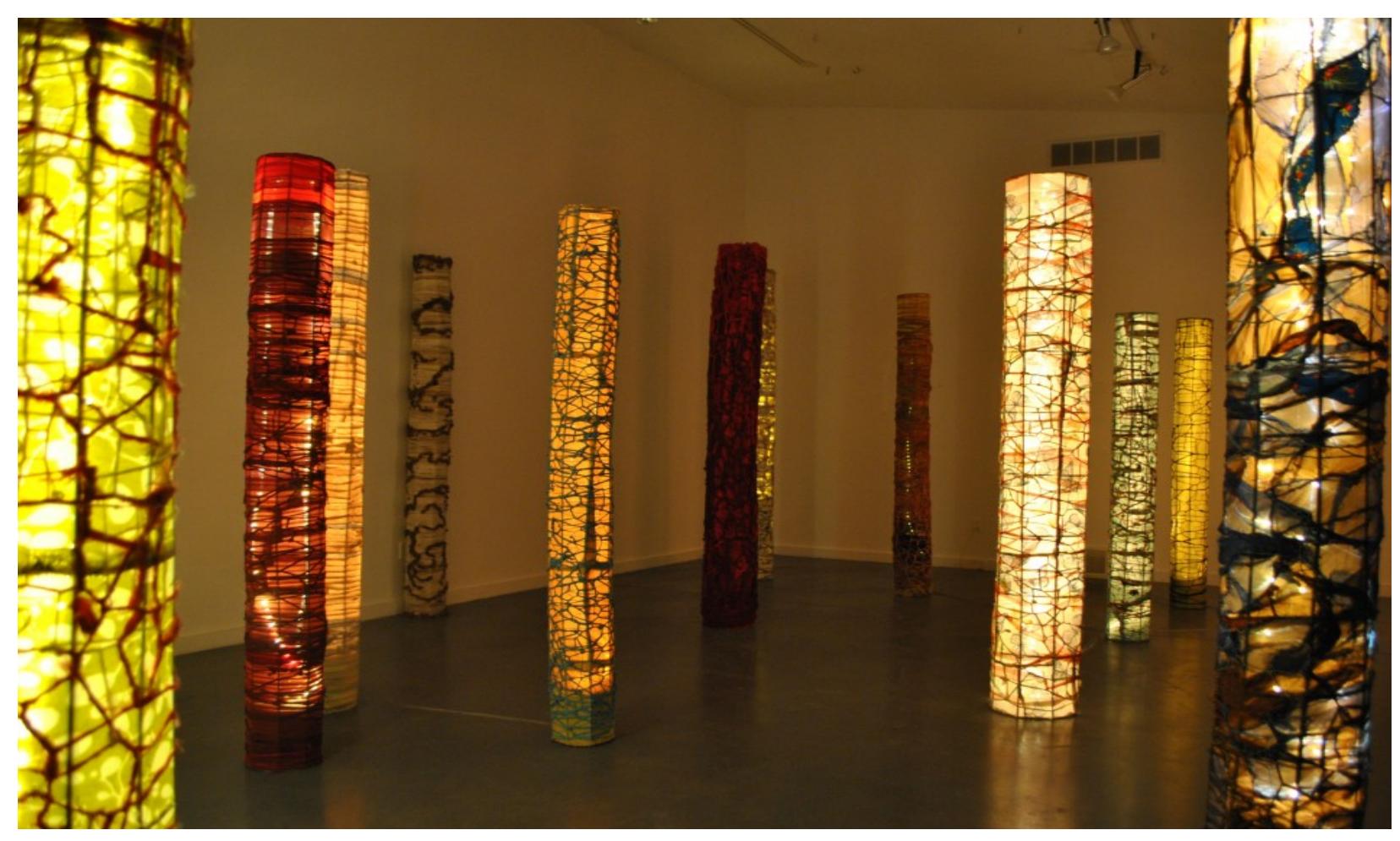

Figure 4

By having color changing light inside the columns, color inside could be created in a gradient, reinforcing the idea of line, and drawing your eye upwards. The "column topper" was an ornery, which was also lit from above, so at any given time within the show, color could complement or contrast depending on the scene. Soon after, LED tape was discussed as an additional lighting source to help provide additional interest within the set. Combining these color changing elements allowed for an otherwise static set to be dynamic, morphing to fit the mood of each scene.

\section{Rental Equipment}

Coordinating the ideas of blacklight/UV from the initial design conversation, as well as the columns and color needs, it became apparent the current inventory wouldn't be sufficient. A rental package of LED wash fixtures (Appendix 1) was then prepared to accommodate the 
expanding color needs for the production. There are limited rental options in the Morgantown, WV market, so a rental from Vincent Lighting Systems in Pittsburgh was arranged. This early commitment to rented LEDs would end up driving most of the remaining design, both aesthetically and budgetarily. A significant portion, $\$ 1760$ of the $\$ 2000$ lighting budget was spent on the rental, and what remained was quickly spent on gel and wiring/LED supplies for the Monostatos mask/costume piece.

The director also became quickly interested in exploring lower side light angles. He worried that the lighting wouldn't be dramatic enough and saw side lighting as a possibility to provide dramatic looks. I agreed, and worked to provide some different options, including lighting ladders and booms. It became apparent that booms would be the best option to achieve these goals, given the lack of scenery that entered through the wings and somewhat limited load in timeframe. Utilizing this low angle position of light, the rented LED wash fixtures provided infinite color options, including UV, and helped tone both the set and performers. Several pairs of Source 4 incandescent fixtures were used for texture washes and additional punch of cool blues and warm ambers. These less saturate colors are not well produced by the LED fixtures, so hanging additional units alleviated concerns that I could produce enough intensity in these colors. Due to the width of the stage, nearly 60 ', it became clear that in order for the Source $4 \mathrm{~s}$ to provide enough light to cover the entire width of the stage, I would need multiple fixtures in the same position. By doubling the fixtures in pairs, and using less saturate colors, 2 fixtures per color on each of the four booms per side provided an even and intense wash of light. By using this position in conjunction with haze, clear visual lines were drawn in the air providing a frame to each scene onstage. 


\section{Collaboration}

Once these major lighting concepts were decided, the process of working through the show scene by scene began. I prepared a rough breakdown of scenes/songs, so that I could process the overall flow of the show and begin to think about how the lighting looks would help reinforce the emotions of each song and location. The director, Cornel Gabara, had a clear approach to the opera, trying to bring out the comedy in each moment. An initial parallel was drawn between this opera's characters and those in "A Midsummer Night's Dream" by William Shakespeare in one of the design meetings. This comparison would prove useful in understanding how the director viewed the power dynamics and relationships among the characters, as well as helping ensure people were on the same page when considering the motivations of the characters. These conversations allowed for moments to be jointly discovered, such as using choreography to sync with LED tape color shifts on steps, or color coordination for songs and props. The long design process provided a wide variety of initial ideas as to the mood and look of each scene. Through the ongoing conversations and trust that was built, I was able to further clarify the director's vision, and helped enhance and focus moments within the show that lacked a clear direction.

Once I completed this breakdown of scenes/songs, (Appendix 2), I contacted the director to arrange a final meeting to ensure we were on the same page before everyone left for the month of December. Having the scenic/projections designer present in this meeting was useful, as design ideas from projections and lighting frequently influenced one another. Collaborations included where scenic and lighting changes should occur, as well as coordinating color and projected content to achieve visual unity. This first meeting lasted nearly 2 hours, and we only completed Act 1. However, everyone was very satisfied that we were on the same page and 
decided to schedule another meeting to finish talking through the show. These meetings were essential, as it meant that some pressure was relieved from the two weeks we would have when we came back from break before load in. Having these meetings saved valuable tech time, because even prior to paper tech, the director knew what to expect, and as a result, several sequences were able to be run only once during tech.

\section{Execution}

\section{Overture}

The opening of this opera was an overture that the director had identified as a moment he wished to use as a "story of creation". Tying the overture to a six-minute video sequence crafted by the scenic designer was no small feat, further increased in complexity by adding lighting

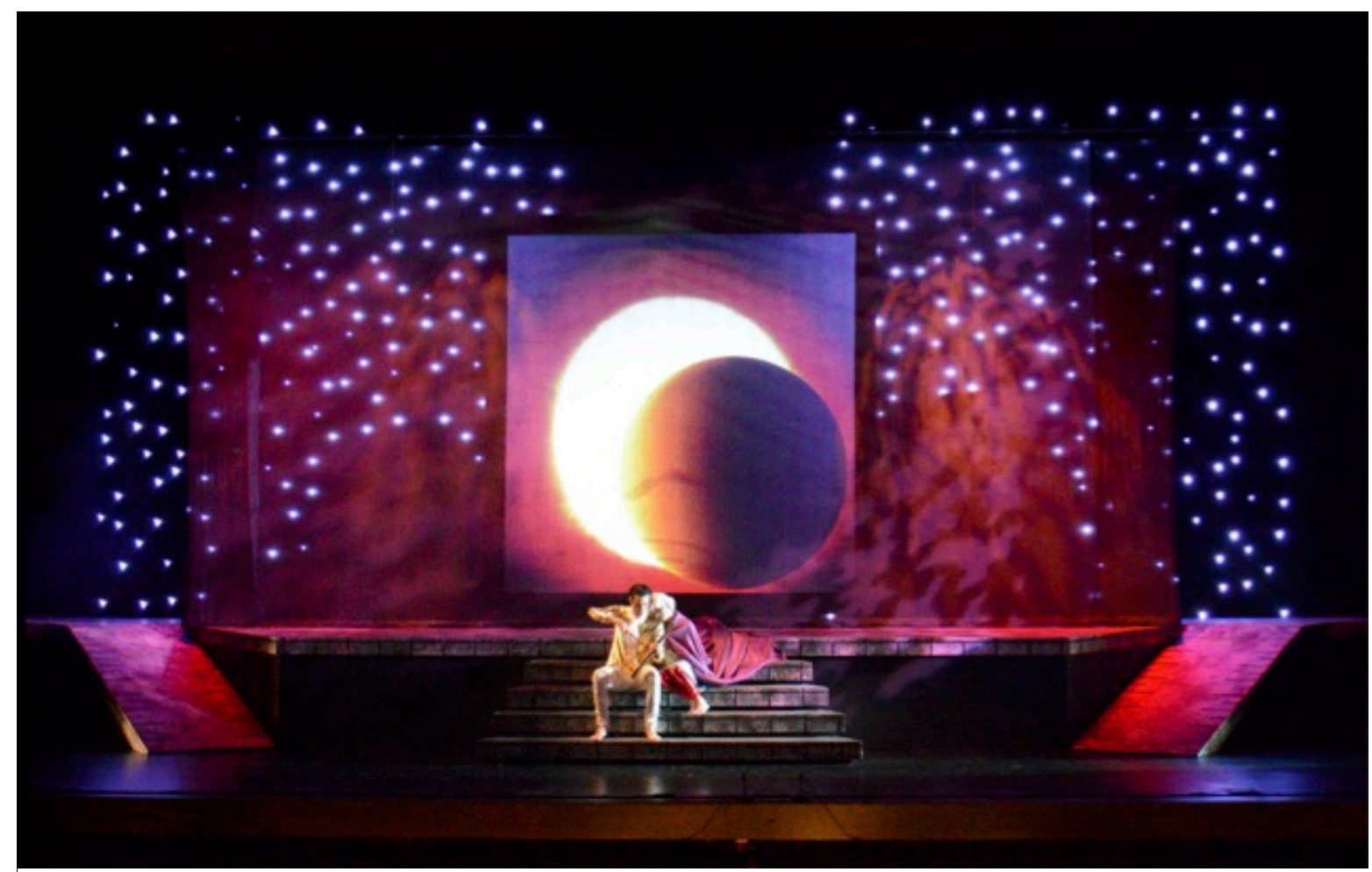

Figure 5

looks and effects to spread the idea out across the stage. Using inspiration from the Book of Genesis in The Bible, the overture took the audience through the creation of man and explored 
our fascination with the cosmos. The sequence ended with the actors portraying Queen of the Night and Sarastro crafting the magic flute in secrecy and presenting the idea to the audience that the two were in contact/coordination the entire time. The overture projection was a combination of stock and custom video and still images knitted together by the scenic designer. Lighting looks accompanied each of the major shifts in the overture, and colors varied from blue-greens to reds and golds, as well as differing textures. (Figure 5)

At the conclusion of the overture, Tamino and the serpent enter, aided by vast amounts of

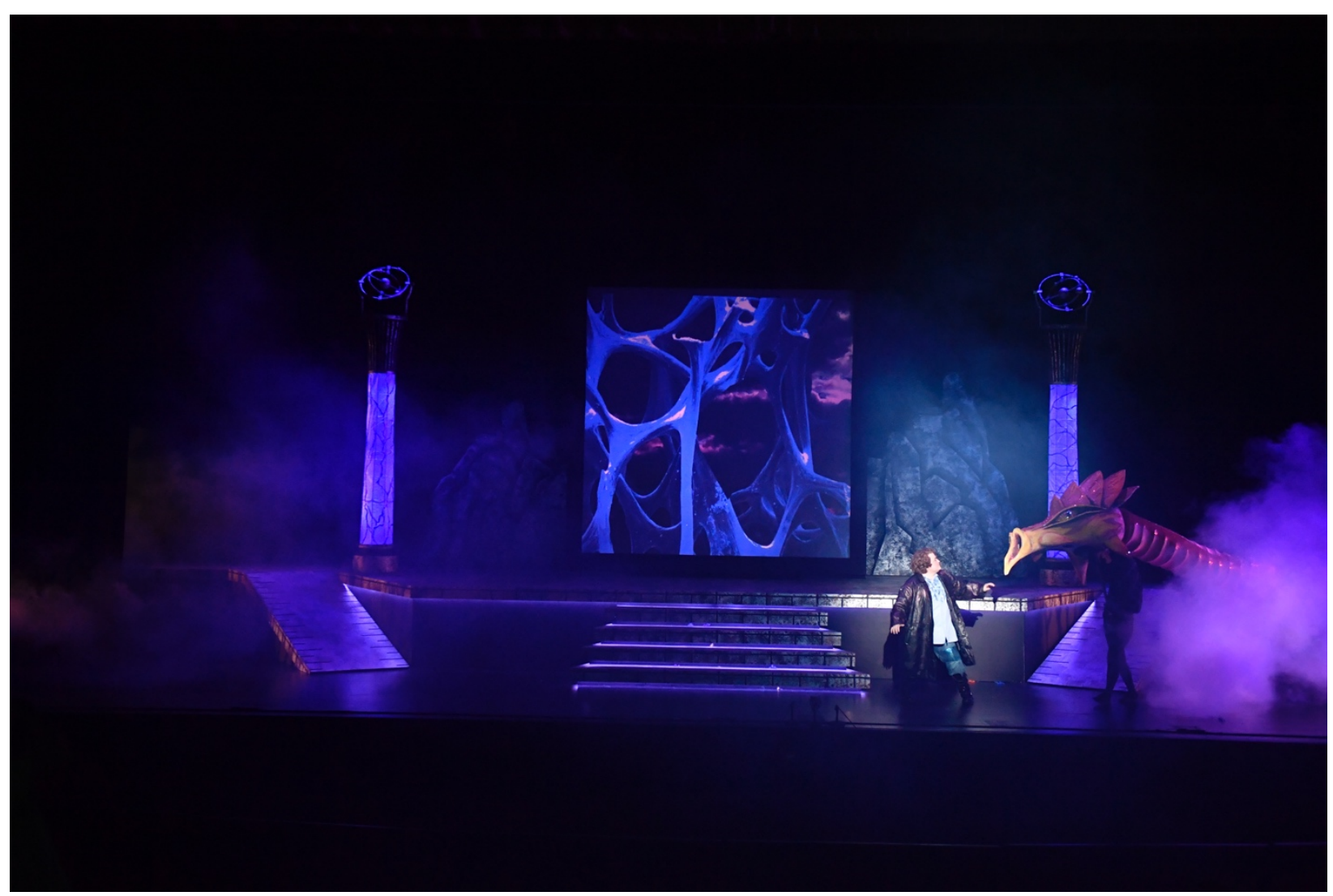

Figure 6

theatrical fog and haze, obscuring the puppeteers who moved the $20+$ ' long puppet across the stage (Figure 6). The scene took place in "a rough and rocky landscape" and the lighting 
reflected this with blues and cool lavenders, remaining dark enough to keep a sense of fear and danger.

\section{Papageno}

As Papageno enters, he brings his happy attitude with him. The lighting matched his joyous singing by warming up the stage and becoming less ominous. Throughout the show, whenever Papageno would enter, this same lighting idea would be executed, and from whatever wing he entered, a glowing warmth would come up just as he appeared. (Figure 7)

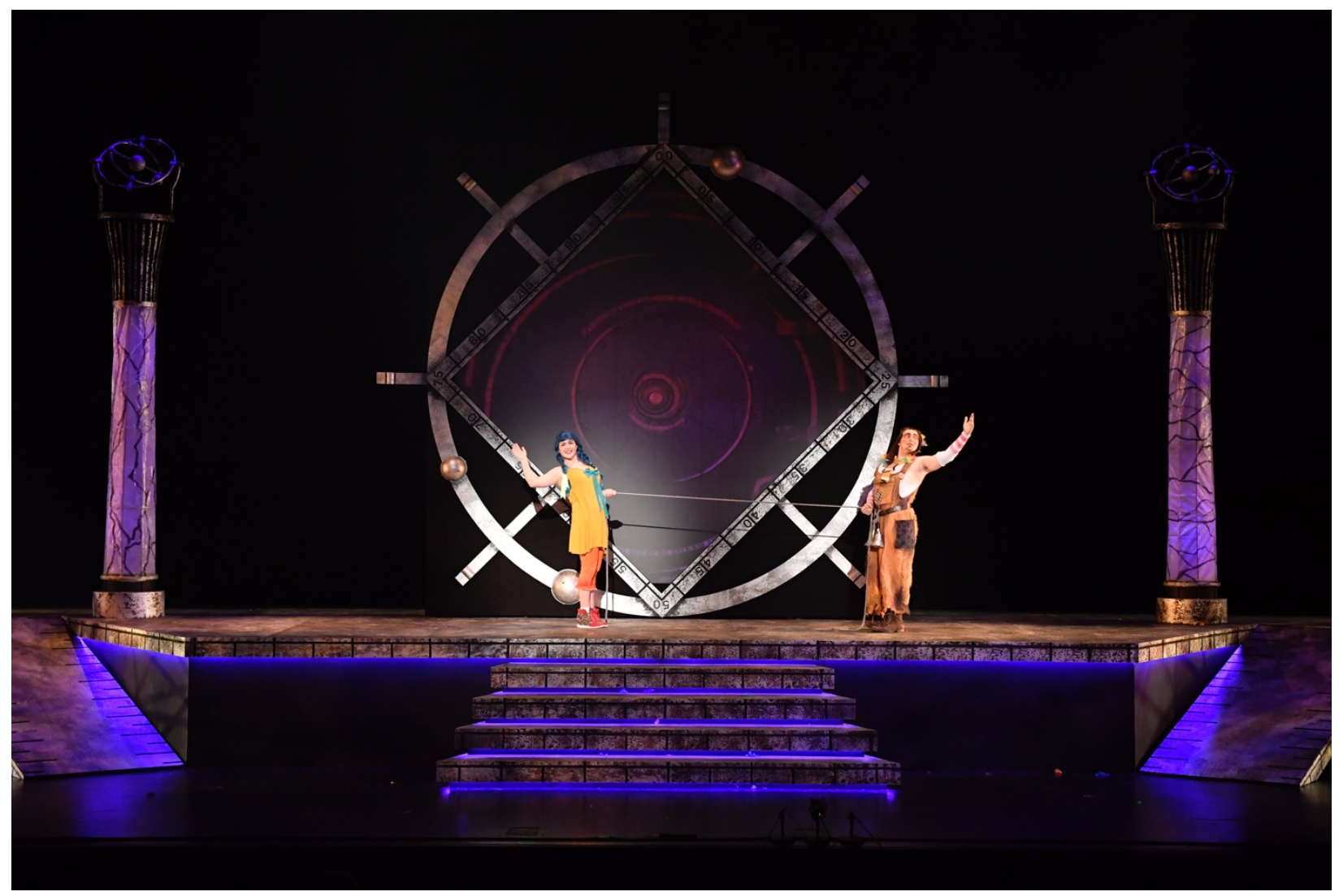

Figure 7

This helped not only provide breaks from the sometimes bleak and cold lighting looks, but also provided a visual indicator of Papageno movement. Having setup the idea for the audience that 
warm light means Papageno is coming allowed for later moments in the show where the same light would be used in various forms for Papagena, his counterpart and lover.

\section{Queen of the Night's Entrance}

The next major moment was the Queen's entrance. From early on, the idea was that the upstage projection screen would rise, and The Queen of the Night would enter with intense red backlight and fog. (Figure 8)

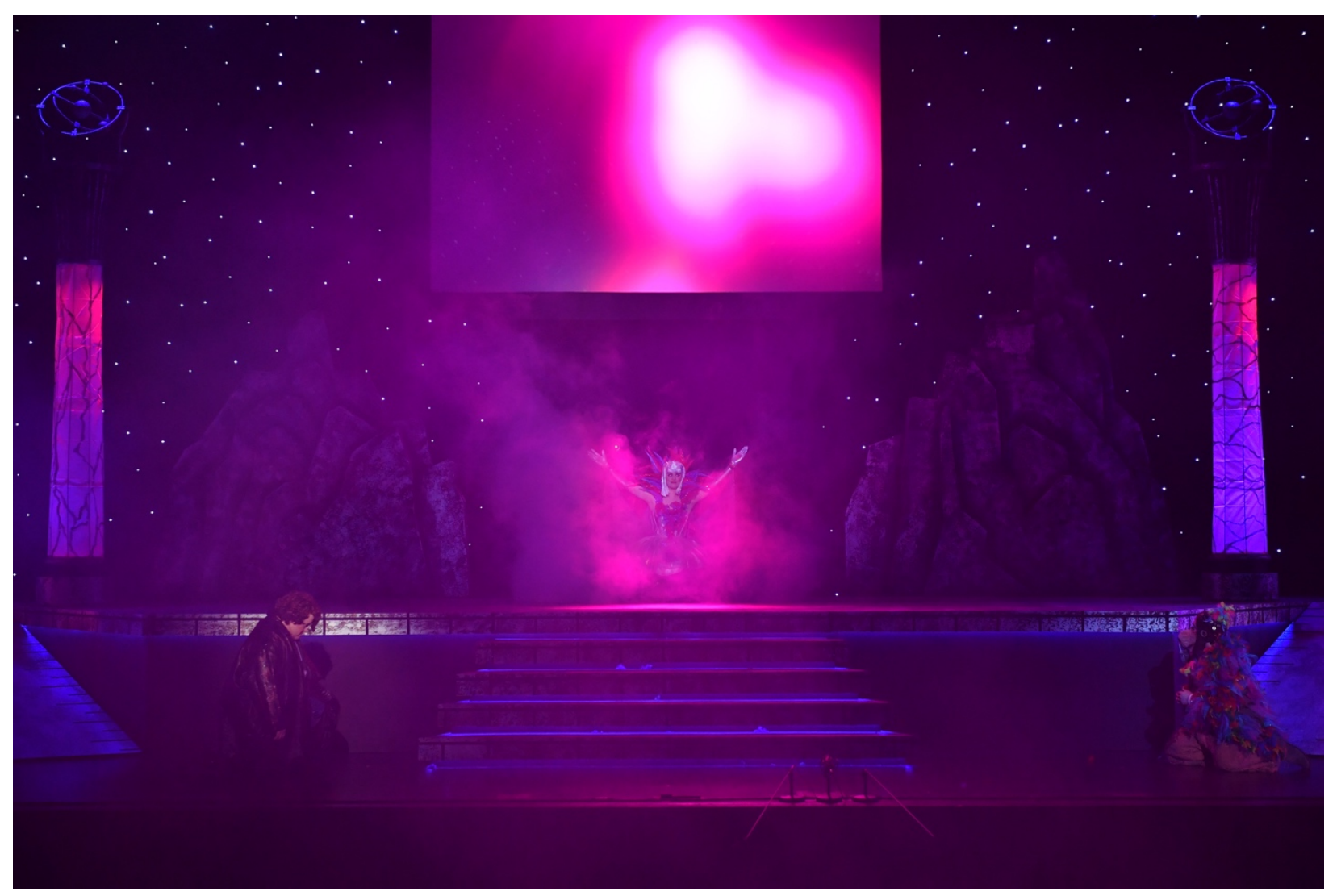

Figure 8

This moment would convey her power and provide the most stunning visual spectacle of the production. The intensity of this moment would only be comparable to her and Sarastro's later entrances in the production. In addition to her powerful entrance, her overall presence onstage also allowed for much more dramatic lighting. Saturate blues and purples were used, as well as 
lavender texture washes to help convey her ability to control the atmosphere of the world when she was present. Frequently her entrances would be accompanied by loud crashes of thunder, often repeated several times in quick succession. The lighting mirrored these thunder crashes by flashing/strobing quickly from the LEDs on the booms in a cool white. This effect was repeated, sometimes slowed down or sped up depending on the length of the thunder sound cue throughout the production.

\section{Pamina's Cage}

The next scene after the Queen exits opens with Monostatos dragging in Pamina.

Monostatos is Sarastro's slave/creature he uses to do his evil bidding, and after several different

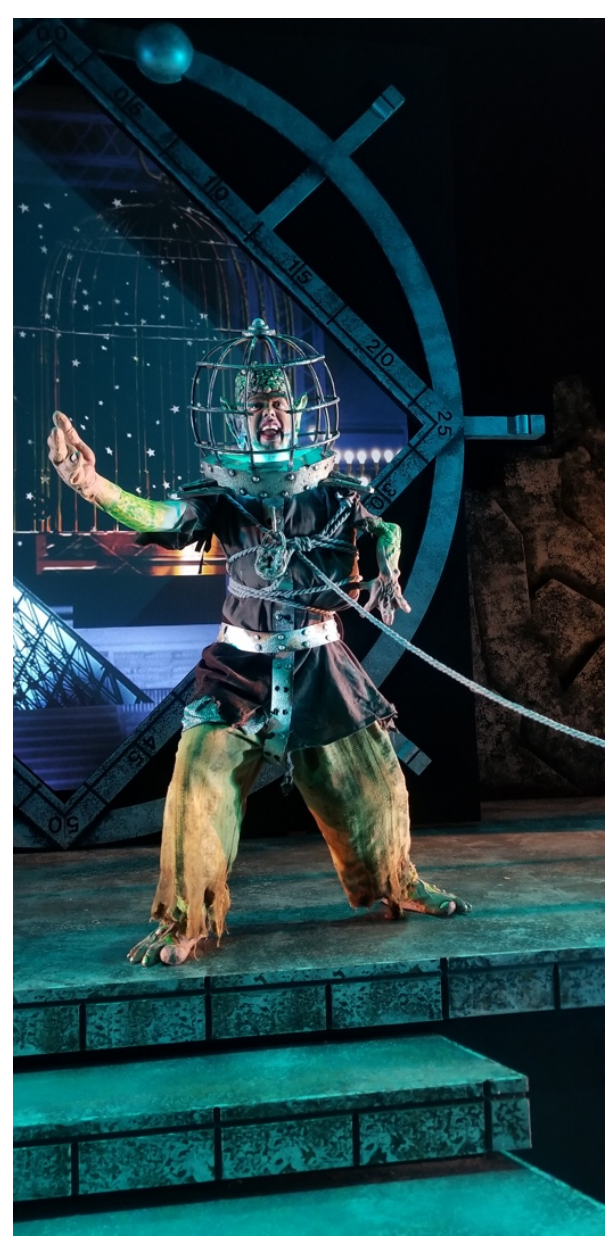

Figure 9 
costume designs, was ultimately a "sewer creature" of sorts, and had a tiny prosthetic arm and a large head piece and mask. To help accent the large cage headpiece, a variety of LED lights were mounted into the cage itself. The back of the cage had a small 12" strip of LED tape installed and wired so it would produce a sickly hue of cyan/green. (Figure 9)

This accent color was in contrast to the 2 cool white LEDs located near the front of the head piece, which provided a sharp up light and ugly shadows onto the prosthetic mask the singer wore. These elements needed to be wireless, so 2 separate battery systems were prepared. The 2 front LEDs needed to run on $12 \mathrm{v}$, so they had a small 8 cell AA battery pack that was located on the headpiece itself. On the headpiece were 2 small 12v A23 batteries wired in series to provide the $24 \mathrm{v}$ power needed for the LED tape. (Figure 10)

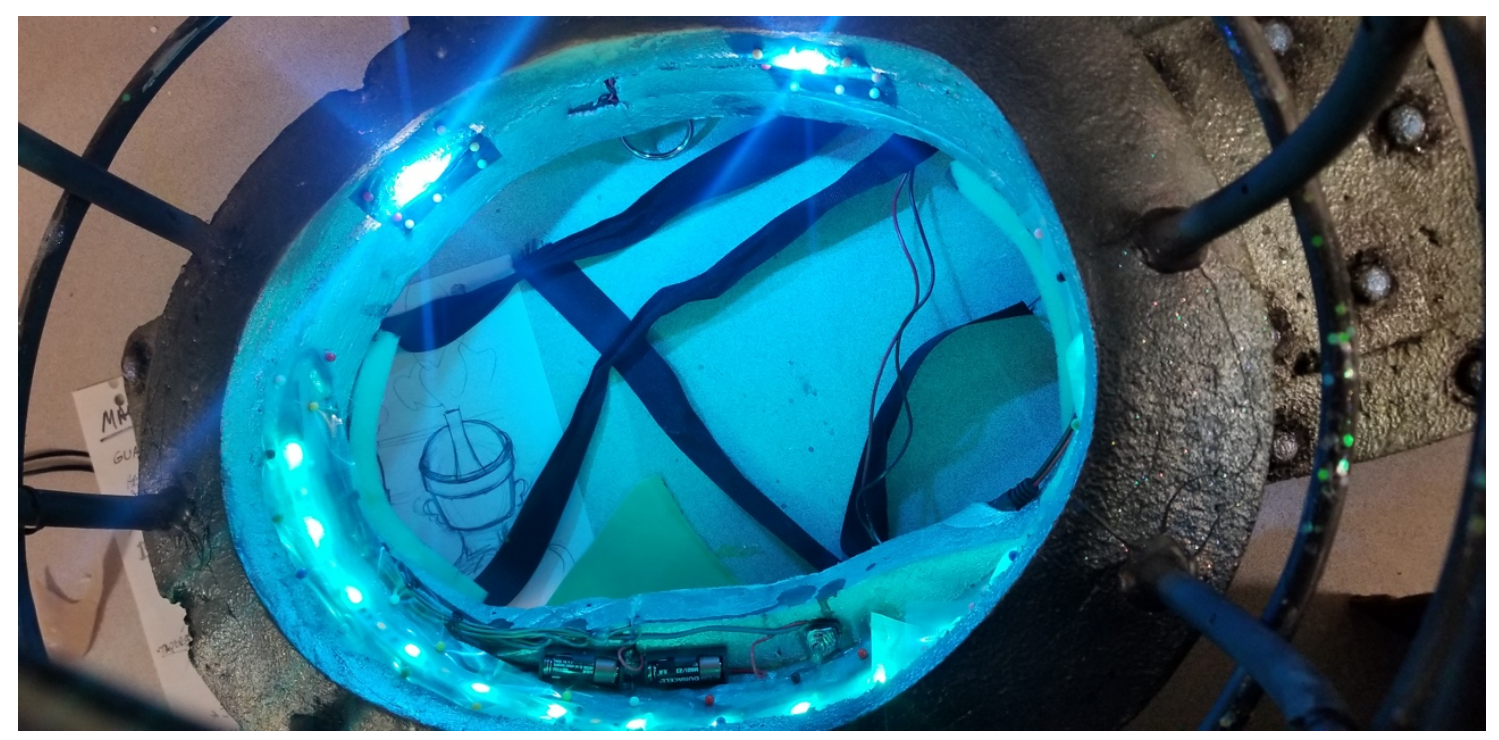

Figure 10

Both of these elements required coordination with the costume designer and puppet creator to ensure all the wiring could be hidden inside the piece. 2 switches were placed on the rear of the head piece so when the performer was offstage, backstage crew could turn off both lights to reduce battery usage and prevent his glow being seen from backstage. The lighting on 
Monostatos was accompanied by stage looks that reflected the cool white light and nasty cyan colors in the headpiece. The stage was washed in cyan light from the sides and tinted the stage to match the grotesqueness of Monostatos. Once Monostatos, Pamina, and Papageno exit, the Act 1 Finale sequence begins.

\section{Act 1 Finale}

The finale for Act 1 is nearly half of the act. The 3 spirits usher Tamino onstage, while Pamina and Papageno are chased on by Monostatos. The madness of the ending is stopped when Sarastro begins his stately entrance. Similar to the Queen's entrance earlier, the upstage projection screen rises, and Sarastro steps through the opening, shrouded in fog and golden light. Once he takes his place on center, an intense white LED light is brought up, that helps separate him from the rest of the people onstage. (Figure 11)

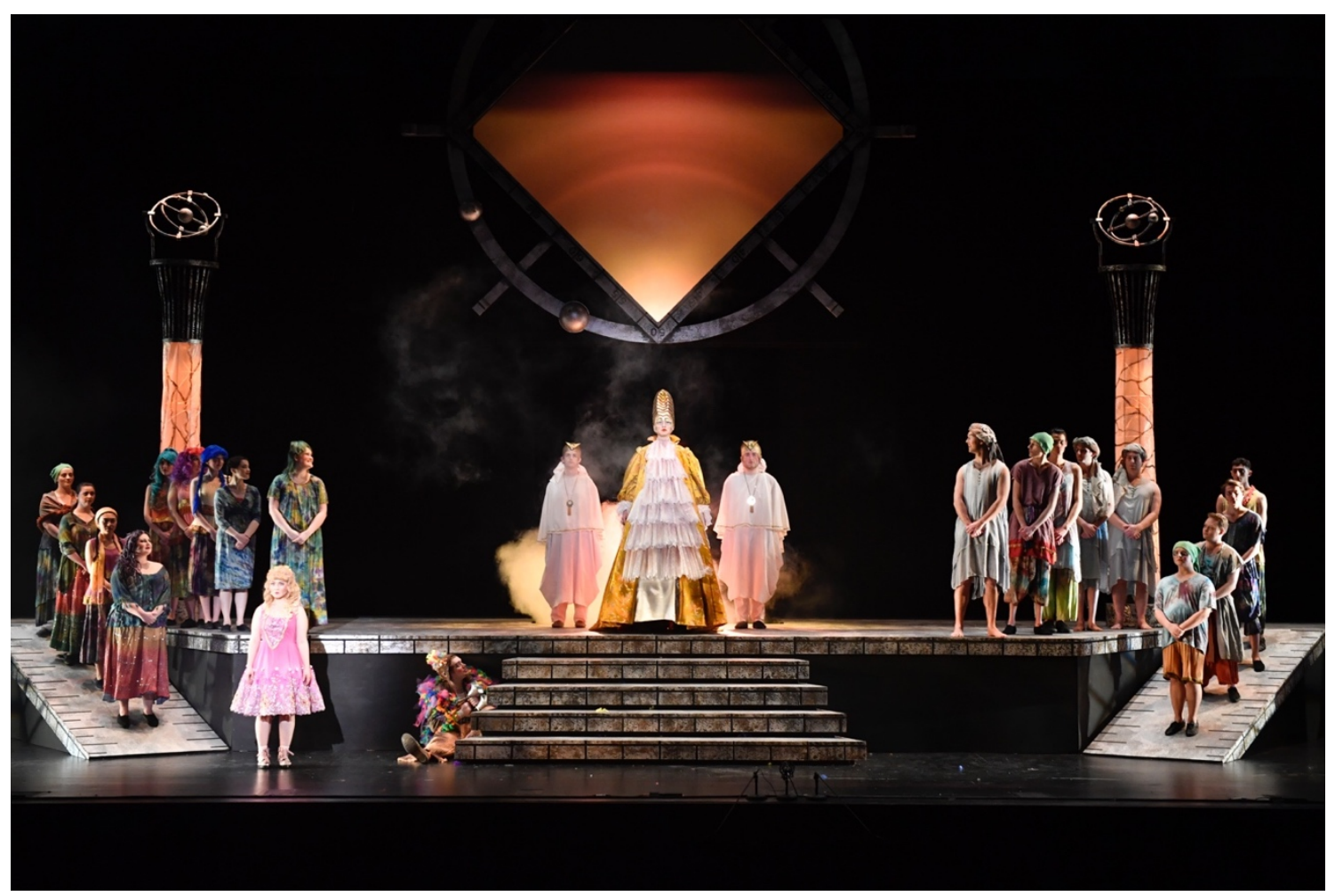

Figure 11 
This intensity and color temperature difference is echoed later during the act 2 finale. In true operatic fashion, the final bars of music are grandiose, and the lighting rose in intensity and warmth as the chorus joined in to end the act.

\section{Act 2 Opening}

Act 2 opens with the priests processing down the aisles of the theatre as the curtain rises to reveal the Queen and Sarastro scheming out their plan with the dagger. While the stage is lit in silhouette, the aisles had a cool texture wash that helps convey the idea of entering an underground temple. The texture was a breakup that represented underground beams and pipes, which helped reinforce the atmosphere for the audience as the priests walked past them in the aisles of the theatre. Tamino and Papageno eventually are blindfolded once they reach the stage, and take their place tied to the columns for a large part of act 2 as they begin the trials to join Sarastro's order.

\section{Fire/Water Trials}

The final trials Papageno and Tamino face are fire and water. The lighting for each matched the projections in color and had a similar effect to create the sense that the light/movement was created from the image represented onstage. Fire consisted of warm tones: oranges, reds, and ambers in a quick flicker. This effect was rolled throughout the LEDs both over the stage on electrics and on the booms from the wings. Water was reflected by using a similar effect, but used cool tones of blue, cyan, and cool whites. This effect was slower and less dramatic to match the waterfall imagery that was projected. After these 2 trials pass, the pace of the act picks up. Again, the finale takes nearly half of the act, and had several sections that flowed quickly from one to the next. To ensure these transitions happened neatly, the director 
would always have one group exiting once side of the stage, and the next entering from the opposite side. This movement allowed for the lighting to immediately begin to crossfade from one side to the next as the first group would exit. As the show begins to wrap up its plotlines, Papageno and Papagena have a joyous song about their love and family, which brings the first of the warm looks nearing the end of act 2.

\section{Act 2 Finale}

After they exit, and Sarastro re-enters with his cadre of priests and onlookers, all the characters come onstage as they profess the goodness of Sarastro and his order and instruct all to follow his path to enlightenment. To help convey the sense of enlightenment, as well as provide a dramatic lighting look worthy of an opera's finale, a system of PAR 64 backlight with light amber gel was used to help push the scene brighter than any other scene in the production. By using this system only once, it helped convey the power of the moment, as well as differentiating the ending finale from the rest of the show.

\section{Technical Process}

\section{Load In}

The execution of the production was fairly seamless, with a few exceptions. The load in was scheduled to begin Monday January $21^{\text {st }}$, and continue until that Friday, the $25^{\text {th }}$ when tech would begin. A known scheduling issue was that the first day of load in would be partly lost due to a university holiday, Martin Luther King Jr. Day. Because of this holiday, student lab crews could not be called in, and only volunteer labor would come in for work. This scheduling challenge meant limited labor on the first day of an already tight load in schedule. On the positive side, we had a full 8-hour work day, uninterrupted from classes and other requirements. 
By the completion of this $1^{\text {st }}$ day of load in, the over stage plot was hung and cabled, and front of house had been started. By Tuesday evening, nearly the entire plot was completed, and prepared for focus on Wednesday.

\section{Focus}

A major challenge for focus was the scenic platform that obstructed Genie lift access to 3 electrics. This meant a $16^{\prime}$ trestle extension ladder was required to access these positions for focus. Having known this in advance, coordination with the technical director had ensured we had an extra platform available at the same height so the ladder could be positioned safely, but I greatly underestimated the additional time moving the platform and ladder would take. A result of this was trying to compensate by moving too quickly with each light, and resulted in some focus errors that would not be addressed until limited work note time the next week after tech. Fortunately, the few errors and dark spots were identified early, so I informed to director in advance of what he would see, so there wasn't any concern when a performer was darker on the upper platform. Throughout the technical process, by maintaining a close dialogue with the director, I was able to assure him that any similar lighting issues like this would be improved.

\section{The Rehearsal Process}

\section{$1^{\text {st }}$ Technical Rehearsal}

The first technical rehearsal went slowly but smoothly. The opening sequence was a difficult sequence to master, requiring lighting, sound, projections, scenery, and performers to move in tandem, seamlessly ending the overture and getting the $25^{\prime}$ 'serpent puppet onstage. An immediate challenge was an opera singer expressing great concern that the fog obstructed their view of the stage and the wing they entered from. By working with the Director and Assistant 
Master Electrician backstage who would operate the fogger throughout the run, a plan was implemented so the look could be achieved without causing discomfort for the performer. By using the fogger in the next wing downstage, the entrance was still obscured to the audience, but the performer could clearly make his way onstage.

Once this $1^{\text {st }}$ challenge was met, tech moved onward until the next difficult sequence, the Queen of the Night's entrance. Again, this sequence required all the elements to work flawlessly together, with the added challenge of inexperienced fly operators safely bringing out and then back in 2 large scenic units, the decorative screen frame and the screen itself. After running the sequence several times, a level of confidence was established that over the subsequent rehearsals the moment could be perfected. Completing this sequence took the remaining time on Friday evening. Everyone left that evening feeling we were in an ok place, knowing that although we didn't have the following morning, scheduled for a long Sitzprobe, we would resume tech that afternoon into the evening.

\section{$2^{\text {nd }}$ Technical Rehearsal}

I came in the next morning of the Sitzprobe and completed a small handful of notes, mostly helping video/projections get things setup while I listened to the singers and the orchestra. Although I left about half way through, hearing parts of the show in context with the orchestra was helpful, particularly moments where orchestrations, vocals, sound effect, and lighting cues would later need to be called together. This allowed me to adjust a few cue timings before we continued tech that afternoon.

Knowing we had limited time to try and finish teching the entire show, we quickly moved from sequence to sequence, and managed to just complete the show by $11 \mathrm{pm}$. Several moments 
that involved lighting and sound effects were only roughed in, as the sound designer wouldn't be present until $1^{\text {st }}$ dress. This decision meant the production team would wait to make adjustments regarding timing of those moments until after the completion of $1^{\text {st }}$ dress, or during if the moment was a major problem. The second tech was overall very smooth from a lighting cue standpoint, so both mine and the director's focus was shifted onto other lighting elements, such as follow spots.

\section{Follow Spots}

Follow spots were a challenge for this production. The operators had never run spotlights before, and the venue's instruments are not in the best condition. An additional challenge was the scale of the show, which contained over 100 spot cues (Appendix 5), coupled with a venue limitation that meant only 1 of the 3 operators could have communication with the stage manager, and I couldn't talk to them during tech. After the $2^{\text {nd }}$ day of tech, a plan was coordinated to use radios to communicate during tech between all 3 spots and myself or the board op. Not having an assistant lighting designer also complicated things in that I had difficulty tracking the changes and adjustment I would tell the 3 spots while also updating the cue sheet for the stage manager and show itself. I relied on the lead spot op to help track the spot cue changes for the group and help me work with them to ensure consistency and accuracy each day. By the end of the technical process, everyone was generally pleased with the improvement and felt confident moving forward into performances.

\section{First Dress Rehearsal}

The first dress rehearsal was very revealing. Several moments were perfectly executed, and most others only needed a few small timing adjustments. While the follow spot operators 
had improved from the previous 2 rehearsals, there was still some work needed, but everyone was still confident that the overall goal was understood. One challenge that presented itself during this rehearsal was the UV effect. After finally seeing the puppets and puppeteers onstage with the lighting looks, the puppeteers didn't disappear quite as intended. While the puppets themselves fluoresced when close to the wings, the LEDs lacked enough punch to really pop when the puppets crossed to center stage. A multi-faceted plan was decided as the best way to approach the problem. Costuming would try and add more UV paint and also coordinate the puppeteer's blacks so they could disappear a bit better. I added the 2 remaining spare LED units I had rented to the $1^{\text {st }}$ electric and used the additional output to help fluoresce the puppets better, as well as achieve better overall coverage over the entire stage. (Figure 12)

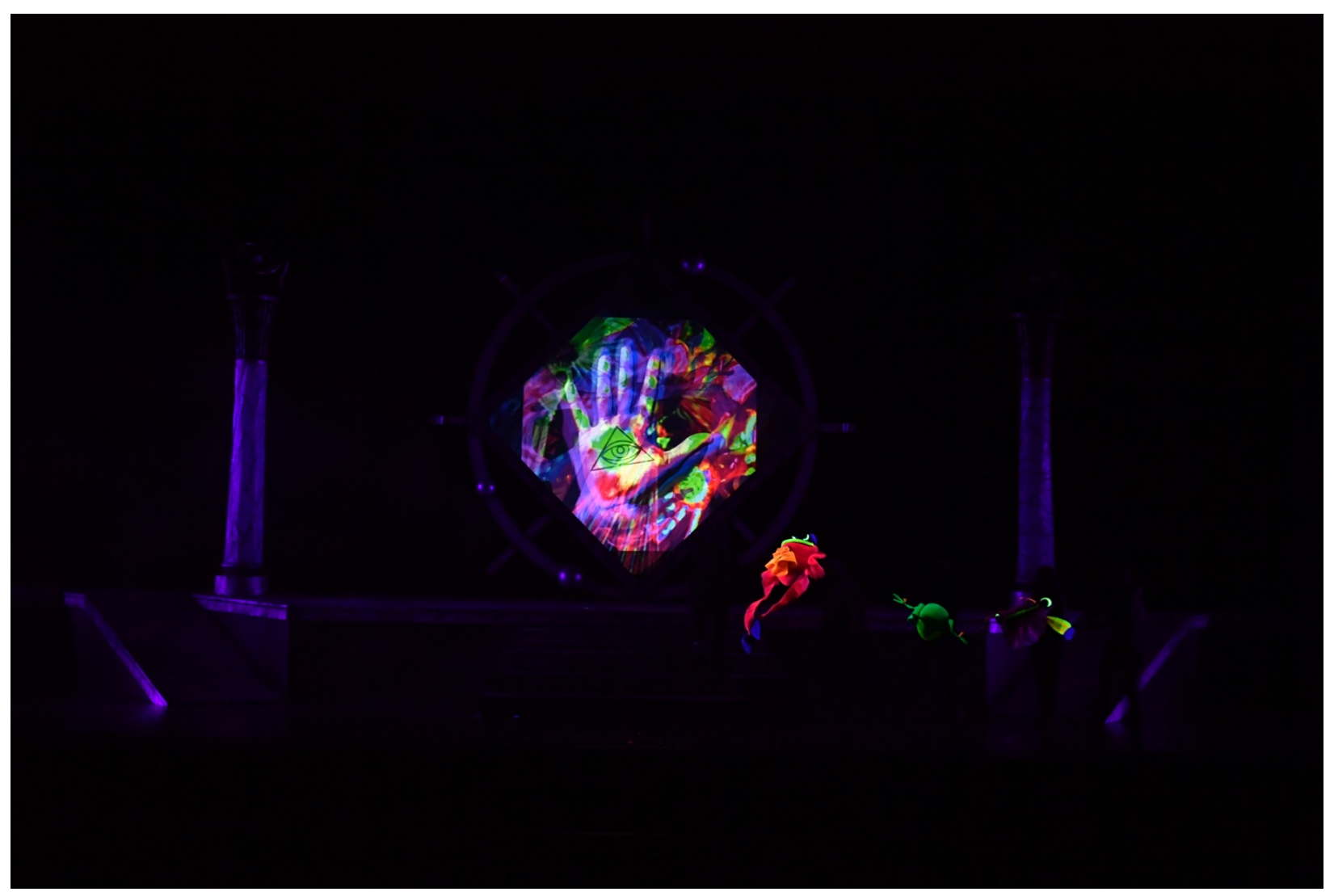

Figure 12 


\section{Second Dress Rehearsal}

Sometime during second dress, the scenic designer asked about what I was planning for curtain warmers and mentioned how creating some shape like a pyramid could be interesting. I thought about it for the next day or so and decided to try creating a large pyramid shape on the curtain for preshow. When the light plot was loaded in, I had designated 6 front of house specials, and had only used one to light the front of the conductor for his bow. Since I hadn't used the remaining specials, I added them to the 4 planned curtain warmer lights. The final result was surprisingly successful and added an interesting motif that echoed the themes of freemasonry throughout the show. (Figure 13)

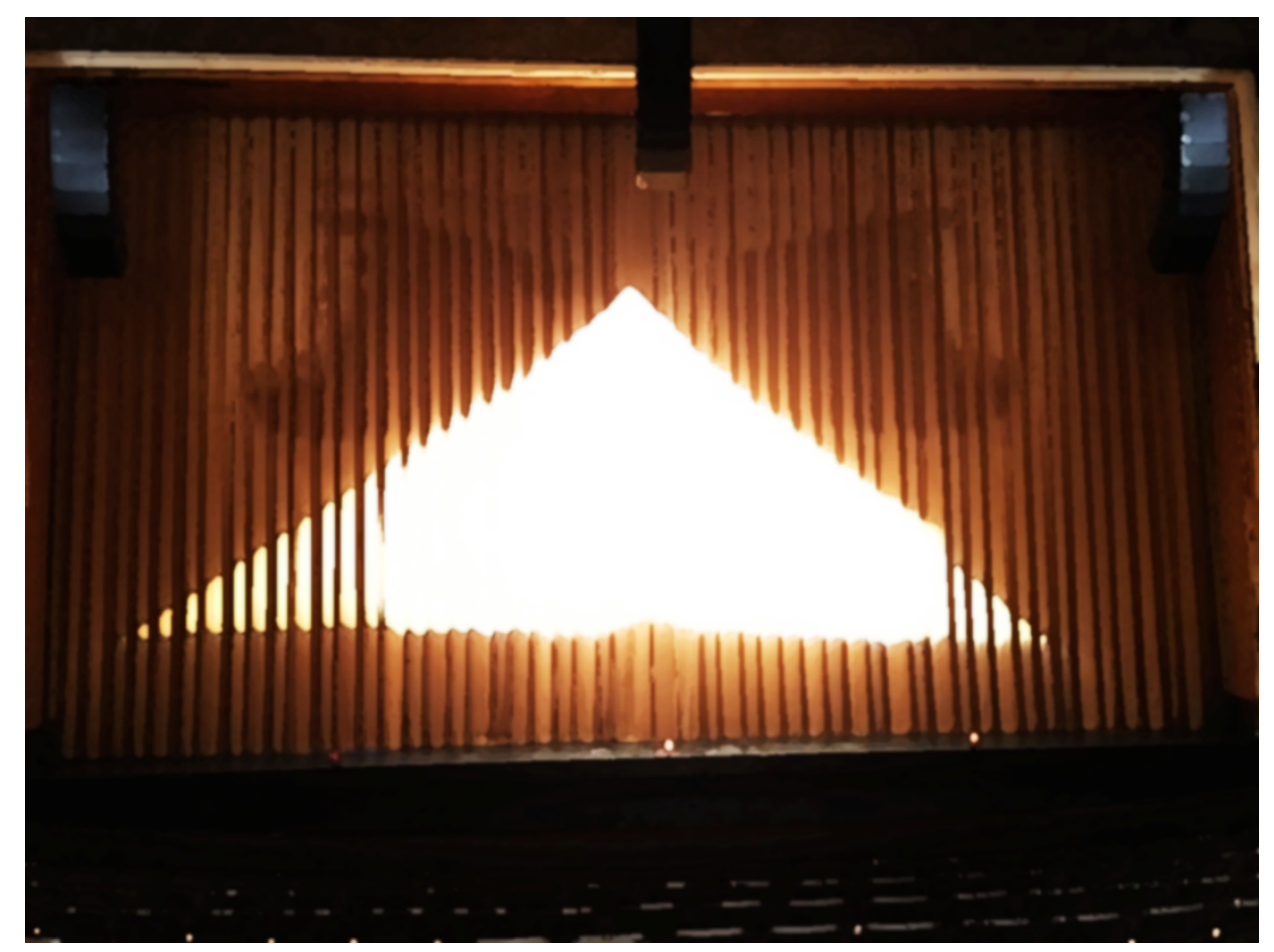

Figure 13

This rehearsal was also the first where the light board and stage manager were moved up into the booth. This was also the only night to see the $2^{\text {nd }}$ cast under light, as well as the first of 
only 2 orchestra rehearsals. This meant any adjustments wouldn't be seen on this cast until opening night, but fortunately there were few changes, mostly limited to follow spot color adjustments due to the complexion of the different Tamino singers.

\section{Final Dress}

Final dress was smooth lighting wise, with the only notes being fog/haze related for consistency, and the overture. The airflow of the Clay theatre is unpredictable, and every night levels had to be adjusted to try and compensate. A determination was made during notes that evening to swap the fog to quick dissipating fog instead of the long-lasting fog used throughout rehearsals. The challenge was we wouldn't see the results of the change until opening night, as we were dark the night before opening. A further complication was university closures that ensued due to "extreme cold weather". Fortunately, swapping out the fog fluid was the only lighting note remaining after final dress, so the change didn't impact lighting much.

\section{Conclusion}

The Magic Flute is an epic opera, filled with epic visual moments. This production captured many of these moments effectively, but some could have been improved. UV moments could have benefitted with more punch and follow spots could have been executed better. It was a struggle to design a production of this scale without an assistant designer. After this process concluded, I realized I have never attempted to design a show of this scale without an assistant tracking changes and helping update paperwork like follow spot cue sheets. After the show opened, there were a handful of moments I saw that could have had an extra cue timed with the score for impact, or small level adjustments to even out the stage. 
Even considering these adjustments I would make; the production was certainly a success. By every metric, the lighting design was implemented effectively. The production remained under budget, achieved the director and team's vision, and provided valuable experiences for the crew. Audiences left the theatre feeling that they witnessed a production that surprised and impressed them, not expecting some of the strong visual choices our production team made. While this production of Mozart's The Magic Flute was not traditional, the modern design choices implemented truthfully reflected the intent of this classical opera. 


\section{Works Cited}

MacPherson, Jay. "The Magic Flute and Freemasonry." University of Toronto Quarterly, vol. 76 no. 4, 2007, pp. 1072-1084. Project MUSE, doi:10.1353/utq.2008.0006

Mozart, Wolfgang Amadeus. The Magic Flute. Translated by Ruth Martin and Thomas Martin, G. Schirmer Inc, 1951.

Muhlestein, Kerry. "European Views of Egyptian Magic and Mystery: A Cultural Context for 'The Magic Flute." Brigham Young University Studies, vol. 43, no. 3, 2004, pp. 137 148. JSTOR, www.jstor.org/stable/43044398. 


\section{Appendices}

\section{Appendix 1: Vincent Lighting Systems Rental Order}

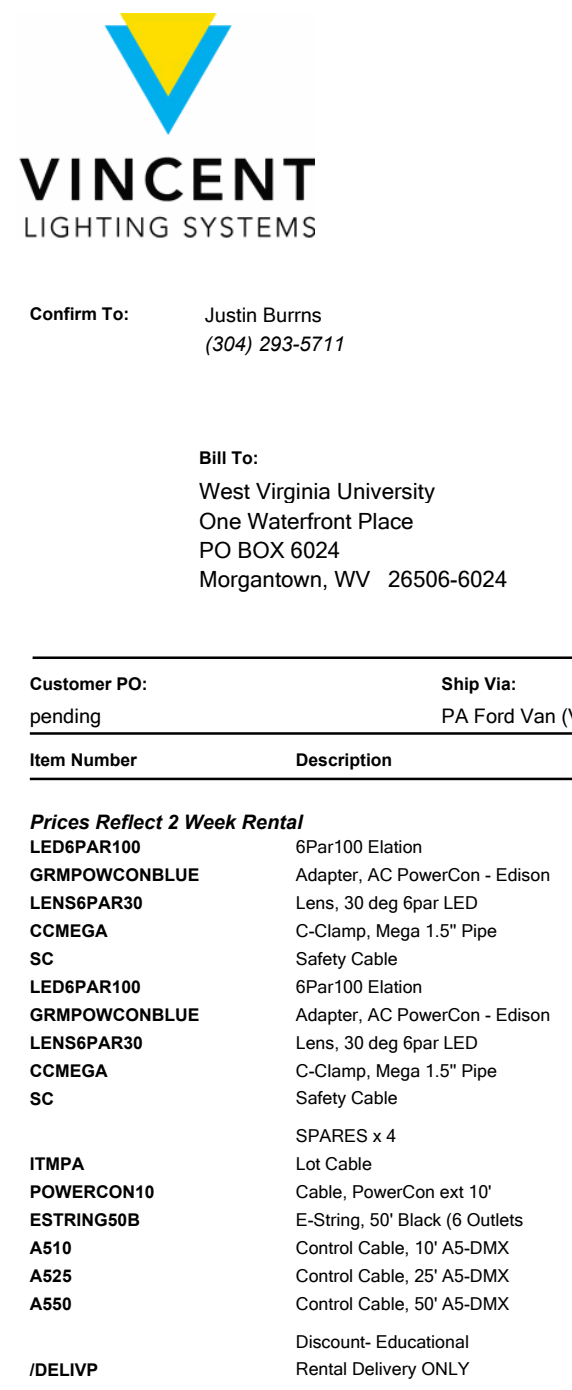

Standard Order

Page 1 of 1

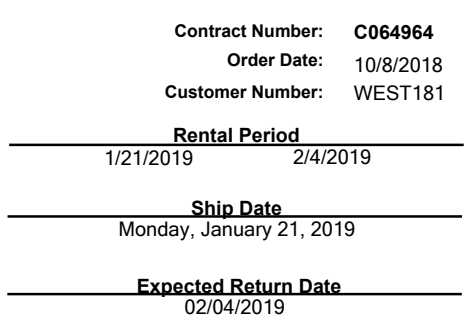

Job: Epars 1.21-2.9

Ship To Address:

West Virginia State University

Creative Arts Center

1 Fine Arts Dr

Morgantown, WV 26506

Terms:

NET 30 DAYS

NOTE: Customer to return gear themselves on 2/4

\begin{tabular}{lll} 
Qty Ordered & Unit Price & Amount \\
\hline
\end{tabular}

\begin{tabular}{rr} 
Net Order: & $1,760.00$ \\
Freight: & 0.00 \\
Sales Tax: & 0.00 \\
Order Total: & $\mathbf{1 , 7 6 0 . 0 0}$ \\
\hline
\end{tabular}




\section{Appendix 2: Scene Breakdown}

\section{Magic Flute 2019 lighting/scene notes:}

Overture:

Fog/haze, lit as characters move through

Blocked moments

1. Introduction
a. Rough and rocky landscape
b. Serpent pursues Tamino
c. 3 Queen of night attendants save Tamino

2. Song
a. Tamino wakes up
b. Papageno enters
c. A bit more forest than rocks?

3. Aria
a. Tamino sings
b. Papageno exits,

4. Queen of night
a. Magical reveal
b. Stars and blood red moon

5. Quintet
a. Papageno/Tamino/3 attendants
b. Shifts to Egyptian at end

6. Trio
a. Monostatos drags Pamina in
b. Egyptian "room"

7. Duet

8. "Finale"
a. Pamina/Papageno
a. 3 spirits enter (projected then UV puppets)
b. Priest in temple
c. "night"
d. Duets throughout
e. End of ACT 1

9. ACT 2 "March of the Priests"
a. "forest of palm trees"
b. Sarastro

10. Aria and Priest Chorus

a. Temple at night at end

11. Duet
a. 2 priests
b. Priests exit and it gets dark

12. Quintet
a. "Night and gloom"
b. Tamino/Papageno/3 ladies 
c. Transition to "garden?"

13. Aria

a. Monostatos

b. Queen of night enters at end (color shift her entrance?)

14. Aria

a. Queen of night

b. Sends Monostatos away?

15. Aria

a. Sarastro

b. Menacing/Bright light

c. Ends with waiting for temple

d. Papagena introduction with 3 spirits

16. Trio

a. 3 spirits intro Papagena

17. Aria

a. Pamina sad song

b. After, Papageno banishes lion with flute

18. Chorus of priests

a. Priests and Sarastro

b. Setting up trials of fire/water

19. Trio

a. Pamina/Tamino/Sarastro

b. After, gets dark, then fire

20. Aria

a. Papageno with glockenspiel

b. Bit happier?

21. Finale

a. 3 spirits

b. Morning light

c. Pamina tries to stab self, stopped by spirits

d. Move scene to "rocky cave with fire and water" (temple) Twilight

e. Adds Tamino

f. Walk through fire and water

g. Then brightly lit temple for "passing tests"

h. Papageno comes in and tries to hang himself, stopped by spirits

i. SCENE to "rocky with queen of night"

j. Ends with temple of sun, brightly lit directional light 


\section{Appendix 3: Lighting Plot}

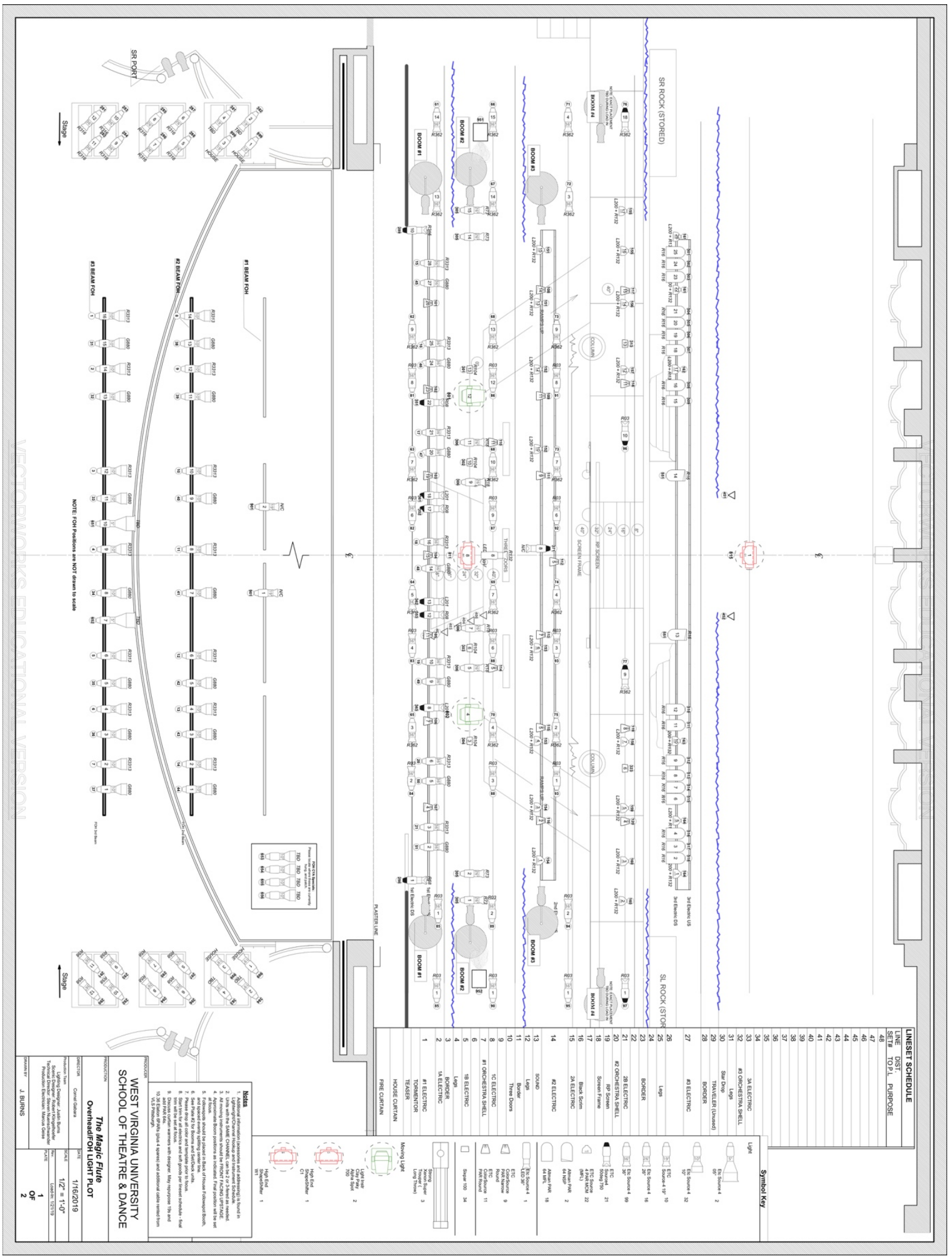




\section{Appendix 4: Channel Hookup}

The Magic Flute

Channel Hookup
Page 1 of 20

$4 / 17 / 19$

The Magic Flute load in.Iw6

$1 / 16 / 19$

Load In: $1 / 21 / 2019$

Opens: $1 / 31 / 2019$

WVU Clay Theatre PE: Marcus Geise

\begin{tabular}{|c|c|c|c|c|c|c|c|}
\hline Channel & Position & U\# & XCoord & Type \& Acc \& Load & Purp & Clr \& Gbo & $\mathrm{Ad}$ \\
\hline (1) & $\begin{array}{l}\text { FOH 3rd } \\
\text { Beam }\end{array}$ & 17 & $-18^{\prime}$ & Source 4 10deg 750w & $\begin{array}{l}\text { warm } \mathrm{ft} \\
\text { in } 1\end{array}$ & R3313 & $\begin{array}{l}1 / \\
92\end{array}$ \\
\hline (2) & $\begin{array}{l}\text { FOH 3rd } \\
\text { Beam }\end{array}$ & 15 & $-14^{\prime}$ & Source 4 10deg $750 w$ & $\begin{array}{l}\text { warm } \mathrm{ft} \\
\text { in } 1\end{array}$ & R3313 & $\begin{array}{l}1 / \\
94\end{array}$ \\
\hline (3) & $\begin{array}{l}\text { FOH 3rd } \\
\text { Beam }\end{array}$ & 13 & $-6^{\prime}-4 "$ & Source 4 10deg 750w & $\begin{array}{l}\text { warm } \mathrm{ft} \\
\text { in } 1\end{array}$ & R3313 & $\begin{array}{l}1 / \\
86\end{array}$ \\
\hline (4) & $\begin{array}{l}\text { FOH 3rd } \\
\text { Beam }\end{array}$ & 11 & $0^{\prime}-5^{\prime \prime}$ & Source 4 10deg $750 w$ & $\begin{array}{l}\text { warm } \mathrm{ft} \\
\text { in } 1\end{array}$ & R3313 & $\begin{array}{l}1 / \\
78\end{array}$ \\
\hline (5) & $\begin{array}{l}\text { FOH 3rd } \\
\text { Beam }\end{array}$ & 7 & 7'-7"' & Source 4 10deg $750 w$ & $\begin{array}{l}\text { warm } \mathrm{ft} \\
\text { in } 1\end{array}$ & R3313 & $\begin{array}{l}1 / \\
79\end{array}$ \\
\hline (6) & $\begin{array}{l}\text { FOH 3rd } \\
\text { Beam }\end{array}$ & 5 & $11^{\prime}-7 "$ & Source 4 10deg $750 w$ & $\begin{array}{l}\text { warm } \mathrm{ft} \\
\text { in } 1\end{array}$ & R3313 & $\begin{array}{l}1 / \\
89\end{array}$ \\
\hline (7) & $\begin{array}{l}\text { FOH 3rd } \\
\text { Beam }\end{array}$ & 3 & 15'-9" & Source 4 10deg $750 w$ & $\begin{array}{l}\text { warm } \mathrm{ft} \\
\text { in } 1\end{array}$ & R3313 & $\begin{array}{l}1 / \\
95\end{array}$ \\
\hline (8) & $\begin{array}{l}\text { FOH 2nd } \\
\text { Beam }\end{array}$ & 14 & $-18^{\prime}$ & Source 4 10deg $750 w$ & $\begin{array}{l}\text { Warm } \\
\text { Ft in } 2\end{array}$ & R3313 & $\begin{array}{l}1 / \\
60\end{array}$ \\
\hline (9) & $\begin{array}{l}\text { FOH 2nd } \\
\text { Beam }\end{array}$ & 12 & $-14^{\prime}$ & Source 4 10deg 750w & $\begin{array}{l}\text { Warm } \\
\text { Ft in } 2\end{array}$ & R3313 & $\begin{array}{l}1 / \\
66\end{array}$ \\
\hline (10) & $\begin{array}{l}\text { FOH 2nd } \\
\text { Beam }\end{array}$ & 10 & $-6^{\prime}-4^{\prime \prime}$ & Source 4 10deg $750 w$ & $\begin{array}{l}\text { Warm } \\
\text { Ft in } 2\end{array}$ & R3313 & $\begin{array}{l}1 / \\
58\end{array}$ \\
\hline (11) & $\begin{array}{l}\text { FOH 2nd } \\
\text { Beam }\end{array}$ & 8 & $0^{\prime}-5^{\prime \prime}$ & Source 4 10deg $750 w$ & $\begin{array}{l}\text { Warm } \\
\text { Ft in } 2\end{array}$ & R3313 & $\begin{array}{l}1 / \\
46\end{array}$ \\
\hline (12) & $\begin{array}{l}\text { FOH 2nd } \\
\text { Beam }\end{array}$ & 6 & 7'-7" & Source 4 10deg $750 w$ & $\begin{array}{l}\text { Warm } \\
\text { Ft in } 2\end{array}$ & R3313 & $\begin{array}{l}1 / \\
43\end{array}$ \\
\hline (13) & $\begin{array}{l}\text { FOH 2nd } \\
\text { Beam }\end{array}$ & 4 & $11^{\prime}-7 "$ & Source 4 10deg $750 w$ & $\begin{array}{l}\text { Warm } \\
\text { Ft in } 2\end{array}$ & R3313 & $\begin{array}{l}1 / \\
53\end{array}$ \\
\hline (14) & $\begin{array}{l}\text { FOH 2nd } \\
\text { Beam }\end{array}$ & 2 & $15^{\prime}-9^{\prime \prime}$ & Source 4 10deg $750 w$ & $\begin{array}{l}\text { Warm } \\
\text { Ft in } 2\end{array}$ & R3313 & $\begin{array}{l}1 / \\
63\end{array}$ \\
\hline (15) & $\begin{array}{l}\text { 1st } \\
\text { Electric US }\end{array}$ & 28 & $-22^{\prime}$ & Source 4 36deg $575 w$ & $\begin{array}{l}\text { Warm ft } \\
\text { in } 3\end{array}$ & R3313 & $\begin{array}{l}1 / \\
126\end{array}$ \\
\hline
\end{tabular}


The Magic Flute

Channel Hookup

Page 2 of 20

$4 / 17 / 19$

The Magic Flute load in.Iw6

\begin{tabular}{|c|c|c|c|c|c|c|c|}
\hline Channel & Position & U\# & XCoord & Type \& Acc \& Load & Purp & Clr \& Gbo & $\mathrm{Ad}$ \\
\hline (16) & $\begin{array}{l}1 \text { st } \\
\text { Electric US }\end{array}$ & 25 & $-16^{\prime}$ & Source 4 36deg 575w & $\begin{array}{l}\text { Warm } \mathrm{ft} \\
\text { in } 3\end{array}$ & R3313 & $\begin{array}{c}1 / \\
120\end{array}$ \\
\hline (17) & $\begin{array}{l}\text { 1st } \\
\text { Electric US }\end{array}$ & 21 & $-9^{\prime}-3^{\prime \prime}$ & Source 4 36deg 575w & $\begin{array}{l}\text { Warm ft } \\
\text { in } 3\end{array}$ & R3313 & $\begin{array}{c}1 / \\
110\end{array}$ \\
\hline (18) & $\begin{array}{l}\text { 1st } \\
\text { Electric US }\end{array}$ & 16 & $-1^{\prime}$ & Source 4 36deg 575w & $\begin{array}{l}\text { Warm ft } \\
\text { in } 3\end{array}$ & R3313 & $\begin{array}{l}1 / \\
98\end{array}$ \\
\hline (19) & $\begin{array}{l}\text { 1st } \\
\text { Electric US }\end{array}$ & 10 & $8^{\prime}$ & Source 4 36deg 575w & $\begin{array}{l}\text { Warm ft } \\
\text { in } 3\end{array}$ & R3313 & $\begin{array}{c}1 / \\
111\end{array}$ \\
\hline (20) & $\begin{array}{l}1 \mathrm{st} \\
\text { Electric US }\end{array}$ & 6 & $15^{\prime}-6^{\prime \prime}$ & Source 4 36deg 575w & $\begin{array}{l}\text { Warm ft } \\
\text { in } 3\end{array}$ & R3313 & $\begin{array}{c}1 / \\
119\end{array}$ \\
\hline (21) & $\begin{array}{l}\text { 1st } \\
\text { Electric US }\end{array}$ & 3 & $20^{\prime}-6^{\prime \prime}$ & Source 4 36deg 575w & $\begin{array}{l}\text { Warm } \mathrm{ft} \\
\text { in } 3\end{array}$ & R3313 & $\begin{array}{c}1 / \\
123\end{array}$ \\
\hline (31) & $\begin{array}{l}\text { FOH 3rd } \\
\text { Beam }\end{array}$ & 16 & $-15^{\prime}-11^{\prime \prime}$ & Source 4 10deg 750w & $\begin{array}{l}\text { Cool Ft } \\
\text { in } 1\end{array}$ & G880 & $\begin{array}{l}1 / \\
96\end{array}$ \\
\hline (32) & $\begin{array}{l}\mathrm{FOH} 3 \mathrm{rd} \\
\text { Beam }\end{array}$ & 14 & $-11^{\prime}-11^{\prime \prime}$ & Source 4 10deg 750w & $\begin{array}{l}\text { Cool Ft } \\
\text { in } 1\end{array}$ & G880 & $\begin{array}{l}1 / \\
90\end{array}$ \\
\hline (33) & $\begin{array}{l}\text { FOH 3rd } \\
\text { Beam }\end{array}$ & 12 & $-4^{\prime}-3^{\prime \prime}$ & Source 4 10deg 750w & $\begin{array}{l}\text { Cool Ft } \\
\text { in } 1\end{array}$ & G880 & $\begin{array}{l}1 / \\
84\end{array}$ \\
\hline (34) & $\begin{array}{l}\text { FOH 3rd } \\
\text { Beam }\end{array}$ & 10 & $0^{\prime}$ & Source 4 10deg 750w & $\begin{array}{l}\text { Cool Ft } \\
\text { in } 1\end{array}$ & G880 & $\begin{array}{l}1 / \\
76\end{array}$ \\
\hline (35) & $\begin{array}{l}\mathrm{FOH} 3 \mathrm{rd} \\
\text { Beam }\end{array}$ & 6 & 9'-8" & Source 4 10deg 750w & $\begin{array}{l}\text { Cool Ft } \\
\text { in } 1\end{array}$ & G880 & $\begin{array}{l}1 / \\
83\end{array}$ \\
\hline (36) & $\begin{array}{l}\text { FOH 3rd } \\
\text { Beam }\end{array}$ & 4 & $13^{\prime}-6^{\prime \prime}$ & Source 4 10deg 750w & $\begin{array}{l}\text { Cool Ft } \\
\text { in } 1\end{array}$ & G880 & $\begin{array}{l}1 / \\
93\end{array}$ \\
\hline (37) & $\begin{array}{l}\text { FOH 3rd } \\
\text { Beam }\end{array}$ & 2 & $17^{\prime}-8^{\prime \prime}$ & Source 4 10deg 750w & $\begin{array}{l}\text { Cool Ft } \\
\text { in } 1\end{array}$ & G880 & $\begin{array}{l}1 / \\
91\end{array}$ \\
\hline (38) & $\begin{array}{l}\mathrm{FOH} 2 \text { nd } \\
\text { Beam }\end{array}$ & 13 & $-15^{\prime}-11^{\prime \prime}$ & Source 4 10deg $750 w$ & $\begin{array}{l}\text { Cool FT } \\
\text { in } 2\end{array}$ & G880 & $\begin{array}{l}1 / \\
64\end{array}$ \\
\hline (39) & $\begin{array}{l}\text { FOH 2nd } \\
\text { Beam }\end{array}$ & 11 & $-11^{\prime}-11^{\prime \prime}$ & Source 4 10deg $750 w$ & $\begin{array}{l}\text { Cool FT } \\
\text { in } 2\end{array}$ & G880 & $\begin{array}{l}1 / \\
62\end{array}$ \\
\hline (40) & $\begin{array}{l}\mathrm{FOH} \text { 2nd } \\
\text { Beam }\end{array}$ & 9 & $-4^{\prime}-3^{\prime \prime}$ & Source 4 10deg $750 w$ & $\begin{array}{l}\text { Cool FT } \\
\text { in } 2\end{array}$ & G880 & $\begin{array}{l}1 / \\
56\end{array}$ \\
\hline
\end{tabular}


The Magic Flute

Channel Hookup

Page 3 of 20

$4 / 17 / 19$

The Magic Flute load in.Iw6

\begin{tabular}{|c|c|c|c|c|c|c|c|}
\hline Channel & Position & U\# & XCoord & Type \& Acc \& Load & Purp & Clr \& Gbo & $\mathrm{Ad}$ \\
\hline (41) & $\begin{array}{l}\text { FOH 2nd } \\
\text { Beam }\end{array}$ & 7 & 2'-10" & Source 4 10deg $750 w$ & $\begin{array}{l}\text { Cool FT } \\
\text { in } 2\end{array}$ & G880 & $\begin{array}{l}1 / \\
44\end{array}$ \\
\hline (42) & $\begin{array}{l}\text { FOH 2nd } \\
\text { Beam }\end{array}$ & 5 & 9'-8" & Source 4 10deg $750 w$ & $\begin{array}{l}\text { Cool FT } \\
\text { in } 2\end{array}$ & G880 & $\begin{array}{l}1 / \\
49\end{array}$ \\
\hline (43) & $\begin{array}{l}\text { FOH 2nd } \\
\text { Beam }\end{array}$ & 3 & $13^{\prime}-6^{\prime \prime}$ & Source 4 10deg 750w & $\begin{array}{l}\text { Cool FT } \\
\text { in } 2\end{array}$ & G880 & $\begin{array}{l}1 / \\
55\end{array}$ \\
\hline (44) & $\begin{array}{l}\text { FOH 2nd } \\
\text { Beam }\end{array}$ & 1 & $17^{\prime}-8^{\prime \prime}$ & Source 4 10deg $750 w$ & $\begin{array}{l}\text { Cool FT } \\
\text { in } 2\end{array}$ & G880 & $\begin{array}{l}1 / \\
67\end{array}$ \\
\hline (45) & $\begin{array}{l}\text { 1st } \\
\text { Electric US }\end{array}$ & 27 & $-20^{\prime}-6 "$ & Source 4 36deg $575 w$ & $\begin{array}{l}\text { Cool ft } \\
\text { in } 3\end{array}$ & G880 & $\begin{array}{c}1 / \\
124\end{array}$ \\
\hline (46) & $\begin{array}{l}\text { 1st } \\
\text { Electric US }\end{array}$ & 24 & $-14^{\prime}-6^{\prime \prime}$ & Source 436 deg $575 \mathrm{w}$ & $\begin{array}{l}\text { Cool ft } \\
\text { in } 3\end{array}$ & G880 & $\begin{array}{c}1 / \\
118\end{array}$ \\
\hline (47) & $\begin{array}{l}\text { 1st } \\
\text { Electric US }\end{array}$ & 20 & $-7^{\prime}-9 "$ & Source 4 36deg 575w & $\begin{array}{l}\text { Cool ft } \\
\text { in } 3\end{array}$ & G880 & $\begin{array}{c}1 / \\
108\end{array}$ \\
\hline (48) & $\begin{array}{l}\text { 1st } \\
\text { Electric US }\end{array}$ & 14 & $1^{\prime}$ & Source 4 36deg $575 w$ & $\begin{array}{l}\text { Cool ft } \\
\text { in } 3\end{array}$ & G880 & $\begin{array}{l}1 / \\
97\end{array}$ \\
\hline (49) & $\begin{array}{l}\text { 1st } \\
\text { Electric US }\end{array}$ & 9 & 9'-6" & Source 4 36deg $575 w$ & $\begin{array}{l}\text { Cool ft } \\
\text { in } 3\end{array}$ & G880 & $\begin{array}{c}1 / \\
113\end{array}$ \\
\hline (50) & $\begin{array}{l}1 \text { st } \\
\text { Electric US }\end{array}$ & 5 & $17^{\prime}$ & Source 4 36deg $575 w$ & $\begin{array}{l}\text { Cool ft } \\
\text { in } 3\end{array}$ & G880 & $\begin{array}{c}1 / \\
121\end{array}$ \\
\hline (51) & $\begin{array}{l}\text { 1st } \\
\text { Electric US }\end{array}$ & 2 & $22^{\prime}$ & Source 4 36deg 575w & $\begin{array}{l}\text { Coolft } \\
\text { in } 3\end{array}$ & G880 & $\begin{array}{c}1 / \\
127\end{array}$ \\
\hline \multirow[t]{2}{*}{ (61) } & $\begin{array}{l}\text { 1A Elec } \\
\text { LS\# } 2\end{array}$ & 3 & $-27^{\prime}$ & Source 4 36deg 575w & $\begin{array}{l}\text { SR HS } \\
\text { in } 1\end{array}$ & R362 & $\begin{array}{c}1 / \\
200\end{array}$ \\
\hline & $"$ & 4 & $-33^{\prime}$ & $"$ & $"$ & $"$ & $"$ \\
\hline (62) & $\begin{array}{l}1 \mathrm{st} \\
\text { Electric DS }\end{array}$ & 9 & $-17^{\prime}$ & Source 4 36deg $575 w$ & $\begin{array}{l}\text { SR HS } \\
\text { in } 1\end{array}$ & R362 & $\begin{array}{c}1 / \\
122\end{array}$ \\
\hline (63) & $\begin{array}{l}\text { 1st } \\
\text { Electric DS }\end{array}$ & 7 & $-7^{\prime}$ & Source 4 36deg $575 w$ & $\begin{array}{l}\text { SR HS } \\
\text { in } 1\end{array}$ & R362 & $\begin{array}{c}1 / \\
106\end{array}$ \\
\hline (64) & $\begin{array}{l}\text { 1st } \\
\text { Electric DS }\end{array}$ & 5 & $3^{\prime}$ & Source 4 36deg $575 w$ & $\begin{array}{l}\text { SR HS } \\
\text { in } 1\end{array}$ & R362 & $\begin{array}{c}1 / \\
101\end{array}$ \\
\hline (65) & $\begin{array}{l}\text { 1st } \\
\text { Electric DS }\end{array}$ & 3 & $13^{\prime}$ & Source 4 36deg 575w & $\begin{array}{l}\mathrm{SR} H S \\
\text { in } 1\end{array}$ & R362 & $\begin{array}{c}1 / \\
117\end{array}$ \\
\hline
\end{tabular}


The Magic Flute

Channel Hookup

Page 4 of 20

$4 / 17 / 19$

The Magic Flute load in.Iw6

\begin{tabular}{|c|c|c|c|c|c|c|c|}
\hline Channel & Position & U\# & XCoord & Type \& Acc \& Load & Purp & Clr \& Gbo & $\mathrm{Ad}$ \\
\hline (66) & $\begin{array}{l}\text { 1C Elec } \\
\text { LS\# } 8\end{array}$ & 15 & $-33^{\prime}$ & Source 4 36deg 575w & $\begin{array}{l}\text { SR HS } \\
\text { in } 2\end{array}$ & R362 & $\begin{array}{l}5 / \\
7\end{array}$ \\
\hline (67) & $\begin{array}{l}\text { 1C Elec } \\
\text { LS\# } 8\end{array}$ & 14 & $-27^{\prime}$ & Source 4 36deg 575w & $\begin{array}{l}\text { SR HS } \\
\text { in } 2\end{array}$ & R362 & $\begin{array}{l}5 / \\
8\end{array}$ \\
\hline \multirow[t]{2}{*}{ (68) } & $\begin{array}{l}\text { 1C Elec } \\
\text { LS\# } 8\end{array}$ & 10 & -7 & Source 4 36deg 575w & $\begin{array}{l}\text { SR HS } \\
\text { in } 2\end{array}$ & R362 & $\begin{array}{l}5 / \\
10\end{array}$ \\
\hline & $"$ & 13 & $-17^{\prime}$ & $"$ & $"$ & $"$ & $"$ \\
\hline (69) & $\begin{array}{l}\text { 1C Elec } \\
\text { LS\# } 8\end{array}$ & 7 & $3^{\prime}$ & Source 4 36deg 575w & $\begin{array}{l}\text { SR HS } \\
\text { in } 2\end{array}$ & R362 & $\begin{array}{l}5 / \\
5\end{array}$ \\
\hline (70) & $\begin{array}{l}\text { 1C Elec } \\
\text { LS\# } 8\end{array}$ & 4 & $13^{\prime}$ & Source 4 36deg $575 w$ & $\begin{array}{l}\text { SR HS } \\
\text { in } 2\end{array}$ & R362 & $\begin{array}{l}5 / \\
6\end{array}$ \\
\hline (71) & $\begin{array}{l}\text { 2A Elec } \\
\text { LS\# } 15\end{array}$ & 4 & $-33^{\prime}$ & $\begin{array}{l}\text { Source } 436 \mathrm{deg}+6.25 " \\
\text { Tophat } 575 w\end{array}$ & $\begin{array}{l}\text { SR HS } \\
\text { in } 3\end{array}$ & R362 & $\begin{array}{c}1 / \\
198\end{array}$ \\
\hline (72) & $\begin{array}{l}\text { 2A Elec } \\
\text { LS\# } 15\end{array}$ & 3 & $-27^{\prime}$ & $\begin{array}{l}\text { Source } 436 \mathrm{deg}+6.25 " \\
\text { Tophat } 575 w\end{array}$ & $\begin{array}{l}\text { SR HS } \\
\text { in } 3\end{array}$ & R362 & $\begin{array}{c}1 / \\
196\end{array}$ \\
\hline \multirow[t]{2}{*}{ (73) } & $\begin{array}{l}\text { 2nd } \\
\text { Electric US }\end{array}$ & 7 & $-7^{\prime}$ & $\begin{array}{l}\text { Source } 436 \mathrm{deg}+6.25 " \\
\text { Tophat } 575 \mathrm{w}\end{array}$ & $\begin{array}{l}\text { SR HS } \\
\text { in } 3\end{array}$ & R362 & $\begin{array}{c}1 / \\
152\end{array}$ \\
\hline & $"$ & 9 & $-17^{\prime}$ & $"$ & $"$ & $"$ & " \\
\hline (74) & $\begin{array}{l}\text { 2nd } \\
\text { Electric US }\end{array}$ & 4 & $3^{\prime}$ & $\begin{array}{l}\text { Source } 436 \mathrm{deg}+6.25 " \\
\text { Tophat } 575 \mathrm{w}\end{array}$ & $\begin{array}{l}\text { SR HS } \\
\text { in } 3\end{array}$ & R362 & $\begin{array}{c}1 / \\
137\end{array}$ \\
\hline (75) & $\begin{array}{l}\text { 2nd } \\
\text { Electric US }\end{array}$ & 2 & $13^{\prime}$ & $\begin{array}{l}\text { Source } 436 \mathrm{deg}+6.25 " \\
\text { Tophat } 575 w\end{array}$ & $\begin{array}{l}\text { SR HS } \\
\text { in } 3\end{array}$ & R362 & $\begin{array}{c}1 / \\
149\end{array}$ \\
\hline (76) & $\begin{array}{l}\text { 2B Elec } \\
\text { LS\# } 21\end{array}$ & 18 & $-33^{\prime}$ & $\begin{array}{l}\text { ETC Source4 50deg } \\
750750 w\end{array}$ & $\begin{array}{l}\text { SR HS } \\
\text { in } 4\end{array}$ & R362 & $\begin{array}{c}1 / \\
239\end{array}$ \\
\hline (77) & $\begin{array}{l}\text { 2B Elec } \\
\text { LS\# } 21\end{array}$ & 9 & $9^{\prime}$ & $\begin{array}{l}\text { ETC Source4 50deg } \\
750750 w\end{array}$ & $\begin{array}{l}\text { SR HS } \\
\text { in } 4\end{array}$ & R362 & $\begin{array}{c}1 / \\
259\end{array}$ \\
\hline (81) & $\begin{array}{l}\text { 1st } \\
\text { Electric DS }\end{array}$ & 8 & $-13^{\prime}$ & Source 4 36deg $575 w$ & $\begin{array}{l}\text { SL HS } \\
\text { in } 1\end{array}$ & $\mathrm{RO3}$ & $\begin{array}{c}1 / \\
112\end{array}$ \\
\hline (82) & $\begin{array}{l}\text { 1st } \\
\text { Electric DS }\end{array}$ & 6 & $-3^{\prime}$ & Source 4 36deg $575 w$ & $\begin{array}{l}\text { SL HS } \\
\text { in } 1\end{array}$ & $\mathrm{RO3}$ & $\begin{array}{c}1 / \\
100\end{array}$ \\
\hline (83) & $\begin{array}{l}\text { 1st } \\
\text { Electric DS }\end{array}$ & 4 & $7^{\prime}$ & Source 4 36deg 575w & $\begin{array}{l}\text { SL HS } \\
\text { in } 1\end{array}$ & R03 & $\begin{array}{c}1 / \\
109\end{array}$ \\
\hline
\end{tabular}


The Magic Flute load in.Iw6

\begin{tabular}{|c|c|c|c|c|c|c|c|}
\hline Channel & Position & U\# & XCoord & Type \& Acc \& Load & Purp & Clr \& Gbo & $\mathrm{Ad}$ \\
\hline (84) & $\begin{array}{l}\text { 1st } \\
\text { Electric DS }\end{array}$ & 2 & $17^{\prime}$ & Source 4 36deg 575w & $\begin{array}{l}\text { SL HS } \\
\text { in } 1\end{array}$ & R03 & $\begin{array}{c}1 / \\
125\end{array}$ \\
\hline \multirow[t]{2}{*}{ (85) } & $\begin{array}{l}\text { 1A Elec } \\
\text { LS\# } 2\end{array}$ & 1 & $27^{\prime}$ & Source 4 36deg 575w & $\begin{array}{l}\text { SL HS } \\
\text { in } 1\end{array}$ & R03 & $\begin{array}{c}1 / \\
187\end{array}$ \\
\hline & $"$ & 2 & $33^{\prime}$ & $"$ & $"$ & $"$ & $"$ \\
\hline (86) & $\begin{array}{l}\text { 1C Elec } \\
\text { LS\# } 8\end{array}$ & 12 & $-13^{\prime}$ & Source 4 36deg 575w & $\begin{array}{l}\text { SL HS } \\
\text { in } 2\end{array}$ & $\mathrm{RO3}$ & $\begin{array}{l}5 / \\
9\end{array}$ \\
\hline (87) & $\begin{array}{l}\text { 1C Elec } \\
\text { LS\# } 8\end{array}$ & 9 & $-3^{\prime}$ & Source 4 36deg 575w & $\begin{array}{l}\text { SL HS } \\
\text { in } 2\end{array}$ & R03 & $\begin{array}{l}5 / \\
3\end{array}$ \\
\hline \multirow[t]{2}{*}{ (88) } & $\begin{array}{l}\text { 1C Elec } \\
\text { LS\# } 8\end{array}$ & 3 & $17^{\prime}$ & Source 4 36deg $575 w$ & $\begin{array}{l}\text { SL HS } \\
\text { in } 2\end{array}$ & $\mathrm{RO3}$ & $\begin{array}{c}5 / \\
2\end{array}$ \\
\hline & $"$ & 6 & $7^{\prime}$ & $"$ & $"$ & $"$ & $"$ \\
\hline (89) & $\begin{array}{l}\text { 1C Elec } \\
\text { LS\# } 8\end{array}$ & 2 & $27^{\prime}$ & Source 4 36deg 575w & $\begin{array}{l}\text { SL HS } \\
\text { in } 2\end{array}$ & R03 & $\begin{array}{c}5 / \\
1\end{array}$ \\
\hline (90) & $\begin{array}{l}\text { 1C Elec } \\
\text { LS\# } 8\end{array}$ & 1 & $33^{\prime}$ & Source 4 36deg $575 w$ & $\begin{array}{l}\text { SL HS } \\
\text { in } 2\end{array}$ & R03 & $\begin{array}{c}5 / \\
4\end{array}$ \\
\hline (91) & $\begin{array}{l}\text { 2nd } \\
\text { Electric US }\end{array}$ & 8 & $-13^{\prime}$ & $\begin{array}{l}\text { Source } 436 \mathrm{deg}+6.25 " \\
\text { Tophat } 575 w\end{array}$ & $\begin{array}{l}\text { SL HS } \\
\text { in } 3\end{array}$ & $\mathrm{R} 03$ & $\begin{array}{c}1 / \\
148\end{array}$ \\
\hline (92) & $\begin{array}{l}\text { 2nd } \\
\text { Electric US }\end{array}$ & 6 & $-3^{\prime}$ & $\begin{array}{l}\text { Source } 436 \mathrm{deg}+6.25 " \\
\text { Tophat } 575 \mathrm{w}\end{array}$ & $\begin{array}{l}\text { SL HS } \\
\text { in } 3\end{array}$ & R03 & $\begin{array}{c}1 / \\
140\end{array}$ \\
\hline \multirow[t]{2}{*}{ (93) } & $\begin{array}{l}\text { 2nd } \\
\text { Electric US }\end{array}$ & 1 & $17^{\prime}$ & $\begin{array}{l}\text { Source } 436 \mathrm{deg}+6.25 " \\
\text { Tophat } 575 \mathrm{w}\end{array}$ & $\begin{array}{l}\text { SL HS } \\
\text { in } 3\end{array}$ & $\mathrm{RO3}$ & $\begin{array}{c}1 / \\
151\end{array}$ \\
\hline & $"$ & 3 & $7^{\prime}$ & $"$ & $"$ & $"$ & $"$ \\
\hline (94) & $\begin{array}{l}\text { 2A Elec } \\
\text { LS\# } 15\end{array}$ & 2 & $27^{\prime}$ & $\begin{array}{l}\text { Source } 436 \mathrm{deg}+6.25 " \\
\text { Tophat } 575 w\end{array}$ & $\begin{array}{l}\text { SL HS } \\
\text { in } 3\end{array}$ & R03 & $\begin{array}{c}1 / \\
197\end{array}$ \\
\hline (95) & $\begin{array}{l}\text { 2A Elec } \\
\text { LS\# } 15\end{array}$ & 1 & $33^{\prime}$ & $\begin{array}{l}\text { Source } 436 \mathrm{deg}+6.25 " \\
\text { Tophat } 575 \mathrm{w}\end{array}$ & $\begin{array}{l}\text { SL HS } \\
\text { in } 3\end{array}$ & R03 & $\begin{array}{c}1 / \\
195\end{array}$ \\
\hline (96) & $\begin{array}{l}\text { 2B Elec } \\
\text { LS\# } 21\end{array}$ & 10 & $-9^{\prime}$ & $\begin{array}{l}\text { ETC Source4 50deg } \\
750750 w\end{array}$ & $\begin{array}{l}\text { SL HS } \\
\text { in } 4\end{array}$ & $\mathrm{RO3}$ & $\begin{array}{c}1 / \\
249\end{array}$ \\
\hline (97) & $\begin{array}{l}\text { 2B Elec } \\
\text { LS\# } 21\end{array}$ & 1 & $33^{\prime}$ & $\begin{array}{l}\text { ETC Source4 50deg } \\
750750 w\end{array}$ & $\begin{array}{l}\text { SL HS } \\
\text { in } 4\end{array}$ & R03 & $\begin{array}{c}1 / \\
251\end{array}$ \\
\hline (101) & $\begin{array}{l}1 \text { st } \\
\text { Electric US }\end{array}$ & 26 & $-19^{\prime}$ & $\begin{array}{l}\text { ETC ColorSource PAR Narrow } \\
\text { Round }+7.5 \text { "Tophat } 90 \mathrm{w}\end{array}$ & $\begin{array}{l}\text { LED } \\
\text { Downs in } 1\end{array}$ & & $\begin{array}{l}21 \\
61\end{array}$ \\
\hline
\end{tabular}


The Magic Flute load in.Iw6

\begin{tabular}{|c|c|c|c|c|c|c|}
\hline Channel & Position & U\# & XCoord & Type \& Acc \& Load & Clr \& Gbo & $\mathrm{Ad}$ \\
\hline (102) & $\begin{array}{l}\text { 1st } \\
\text { Electric US }\end{array}$ & 23 & $-12^{\prime}-6 "$ & $\begin{array}{l}\text { ETC ColorSource PAR Narrow } \\
\text { Round+7.5" Tophat 90w }\end{array}$ & $\begin{array}{l}\text { LED } \\
\text { Downs in } 1\end{array}$ & $\begin{array}{l}2 / \\
56\end{array}$ \\
\hline (103) & $\begin{array}{l}\text { 1st } \\
\text { Electric US }\end{array}$ & 19 & $-6^{\prime}$ & $\begin{array}{l}\text { ETC ColorSource PAR Narrow } \\
\text { Round+7.5" Tophat } 90 \mathrm{w}\end{array}$ & $\begin{array}{l}\text { LED } \\
\text { Downs in } 1\end{array}$ & $\begin{array}{l}2 / \\
51\end{array}$ \\
\hline (104) & $\begin{array}{l}1 \text { st } \\
\text { Electric US }\end{array}$ & 15 & $0^{\prime}$ & $\begin{array}{l}\text { ETC ColorSource PAR Narrow } \\
\text { Round+7.5" Tophat } 90 \mathrm{w}\end{array}$ & $\begin{array}{l}\text { LED } \\
\text { Downs in } 1\end{array}$ & $\begin{array}{l}2 / \\
46\end{array}$ \\
\hline (105) & $\begin{array}{l}\text { 1st } \\
\text { Electric US }\end{array}$ & 11 & $6^{\prime}$ & $\begin{array}{l}\text { ETC ColorSource PAR Narrow } \\
\text { Round+7.5" Tophat } 90 \mathrm{w}\end{array}$ & $\begin{array}{l}\text { LED } \\
\text { Downs in } 1\end{array}$ & $\begin{array}{l}2 / \\
41\end{array}$ \\
\hline (106) & $\begin{array}{l}\text { 1st } \\
\text { Electric US }\end{array}$ & 7 & $12^{\prime}-6^{\prime \prime}$ & $\begin{array}{l}\text { ETC ColorSource PAR Narrow } \\
\text { Round }+7.5 \text { " Tophat } 90 \mathrm{w}\end{array}$ & $\begin{array}{l}\text { LED } \\
\text { Downs in } 1\end{array}$ & $\begin{array}{l}21 \\
36\end{array}$ \\
\hline (107) & $\begin{array}{l}1 \text { st } \\
\text { Electric US }\end{array}$ & 4 & $19^{\prime}$ & $\begin{array}{l}\text { ETC ColorSource PAR Narrow } \\
\text { Round }+7.5 \text { " Tophat } 90 \mathrm{w}\end{array}$ & $\begin{array}{l}\text { LED } \\
\text { Downs in } 1\end{array}$ & $\begin{array}{l}2 / \\
31\end{array}$ \\
\hline (108) & $\begin{array}{l}\text { 2nd } \\
\text { Electric DS }\end{array}$ & 14 & $-20^{\prime}$ & $\begin{array}{l}\text { ETC ColorSource PAR Narrow } \\
\text { Round }+7.5^{\prime \prime} \text { Tophat } 90 \mathrm{w}\end{array}$ & $\begin{array}{l}\text { LED } \\
\text { Downs in } 2\end{array}$ & $\begin{array}{c}2 / \\
371\end{array}$ \\
\hline (109) & $\begin{array}{l}\text { 2nd } \\
\text { Electric DS }\end{array}$ & 11 & $-12^{\prime}$ & $\begin{array}{l}\text { ETC ColorSource PAR } \\
\text { Round }+7.5 \text { " Barndoor } 90 \mathrm{w}\end{array}$ & $\begin{array}{l}\text { LED } \\
\text { Downs in } 2\end{array}$ & $\begin{array}{c}21 \\
366\end{array}$ \\
\hline (110) & $\begin{array}{l}\text { 1C Elec } \\
\text { LS\# } 8\end{array}$ & 11 & $-8 '-6 "$ & $\begin{array}{l}\text { ETC ColorSource PAR } \\
\text { Round }+7.5 \text { " Tophat } 90 \mathrm{w}\end{array}$ & $\begin{array}{l}\text { LED } \\
\text { Downs in } 2\end{array}$ & $\begin{array}{c}21 \\
306\end{array}$ \\
\hline (111) & $\begin{array}{l}\text { 2nd } \\
\text { Electric DS }\end{array}$ & 9 & $-6^{\prime}$ & $\begin{array}{l}\text { ETC ColorSource PAR } \\
\text { Round }+7.5 \text { " Barndoor } 90 \mathrm{w}\end{array}$ & $\begin{array}{l}\text { LED } \\
\text { Downs in } 2\end{array}$ & $\begin{array}{c}21 \\
361\end{array}$ \\
\hline (112) & $\begin{array}{l}\text { 2nd } \\
\text { Electric US }\end{array}$ & 5 & 0'-6" & $\begin{array}{l}\text { ETC ColorSource PAR } \\
\text { Round }+7.5 " \text { Barndoor } 90 \mathrm{w}\end{array}$ & $\begin{array}{l}\text { LED } \\
\text { Downs in } 2\end{array}$ & $\begin{array}{c}21 \\
356\end{array}$ \\
\hline (113) & $\begin{array}{l}\text { 2nd } \\
\text { Electric DS }\end{array}$ & 7 & $6^{\prime}$ & $\begin{array}{l}\text { ETC ColorSource PAR } \\
\text { Round }+7.5 \text { " Barndoor } 90 \mathrm{w}\end{array}$ & $\begin{array}{l}\text { LED } \\
\text { Downs in } 2\end{array}$ & $\begin{array}{c}21 \\
351\end{array}$ \\
\hline (114) & $\begin{array}{l}\text { 1C Elec } \\
\text { LS\# } 8\end{array}$ & 5 & 8'-6" & $\begin{array}{l}\text { ETC ColorSource PAR } \\
\text { Round }+7.5 \text { " Tophat } 90 \mathrm{w}\end{array}$ & $\begin{array}{l}\text { LED } \\
\text { Downs in } 2\end{array}$ & $\begin{array}{c}21 \\
301\end{array}$ \\
\hline (115) & $\begin{array}{l}\text { 2nd } \\
\text { Electric DS }\end{array}$ & 5 & $13^{\prime}$ & $\begin{array}{l}\text { ETC ColorSource PAR } \\
\text { Round }+7.5 " \text { Barndoor } 90 \mathrm{w}\end{array}$ & $\begin{array}{l}\text { LED } \\
\text { Downs in } 2\end{array}$ & $\begin{array}{c}21 \\
346\end{array}$ \\
\hline (116) & $\begin{array}{l}\text { 2nd } \\
\text { Electric DS }\end{array}$ & 2 & $20^{\prime}$ & $\begin{array}{l}\text { ETC ColorSource PAR Narrow } \\
\text { Round+7.5" Tophat } 90 \mathrm{w}\end{array}$ & $\begin{array}{l}\text { LED } \\
\text { Downs in } 2\end{array}$ & $\begin{array}{c}21 \\
341\end{array}$ \\
\hline (117) & $\begin{array}{l}\text { 2B Elec } \\
\text { LS\# } 21\end{array}$ & 15 & $-19^{\prime}-11^{\prime \prime}$ & $\begin{array}{l}\text { ETC ColorSource PAR } \\
\text { Round }+7.5^{\prime \prime} \text { Tophat } 90 \mathrm{w}\end{array}$ & $\begin{array}{l}\text { LED } \\
\text { Downs in } 3\end{array}$ & $\begin{array}{r}21 \\
451\end{array}$ \\
\hline (118) & $\begin{array}{l}\text { 2B Elec } \\
\text { LS\# } 21\end{array}$ & 11 & $-12^{\prime}-11^{\prime \prime}$ & $\begin{array}{l}\text { ETC ColorSource PAR } \\
\text { Round }+7.5 \text { " Barndoor } 90 \mathrm{w}\end{array}$ & $\begin{array}{l}\text { LED } \\
\text { Downs in } 3\end{array}$ & $\begin{array}{c}21 \\
431\end{array}$ \\
\hline
\end{tabular}


The Magic Flute load in.Iw6

\begin{tabular}{|c|c|c|c|c|c|c|c|}
\hline Channel & Position & U\# & XCoord & Type \& Acc \& Load & Purp & Clr \& Gbo & $\mathrm{Ad}$ \\
\hline (119) & $\begin{array}{l}\text { 2B Elec } \\
\text { LS\# } 21\end{array}$ & 8 & $13^{\prime}-1 "$ & $\begin{array}{l}\text { ETC ColorSource PAR } \\
\text { Round }+7.5 " \text { Barndoor } 90 \mathrm{w}\end{array}$ & $\begin{array}{l}\text { LED } \\
\text { Downs in } 3\end{array}$ & & $\begin{array}{c}21 \\
426\end{array}$ \\
\hline (120) & $\begin{array}{l}\text { 2B Elec } \\
\text { LS\# } 21\end{array}$ & 4 & $20^{\prime}-1 "$ & $\begin{array}{l}\text { ETC ColorSource PAR } \\
\text { Round }+7.5 \text { " Tophat } 90 \mathrm{w}\end{array}$ & $\begin{array}{l}\text { LED } \\
\text { Downs in } 3\end{array}$ & & $\begin{array}{c}21 \\
411\end{array}$ \\
\hline \multirow[t]{2}{*}{ (151) } & $\begin{array}{l}\text { 2nd } \\
\text { Electric DS }\end{array}$ & 13 & $-19^{\prime}$ & S4 PAR MFL 575w & $\begin{array}{l}\text { Back in } \\
1\end{array}$ & $\begin{array}{l}\mathrm{L} 200+ \\
\mathrm{R} 132\end{array}$ & $\begin{array}{c}1 / \\
144\end{array}$ \\
\hline & $"$ & 15 & $-23^{\prime}$ & $"$ & $"$ & $"$ & $"$ \\
\hline \multirow[t]{2}{*}{ (152) } & $\begin{array}{l}\text { 2nd } \\
\text { Electric DS }\end{array}$ & 10 & $-8^{\prime}$ & $\begin{array}{l}\text { S4 PAR MFL+7.5" } \\
\text { Barndoor } 575 w\end{array}$ & $\begin{array}{l}\text { Back in } \\
1\end{array}$ & $\begin{array}{l}\text { L200 + } \\
\text { R132 }\end{array}$ & $\begin{array}{c}1 / \\
146\end{array}$ \\
\hline & $"$ & 12 & $-14^{\prime}$ & S4 PAR MFL 575w & $"$ & $"$ & $"$ \\
\hline \multirow[t]{2}{*}{ (153) } & $\begin{array}{l}\text { 2nd } \\
\text { Electric DS }\end{array}$ & 4 & $14^{\prime}$ & S4 PAR MFL 575w & $\begin{array}{l}\text { Back in } \\
1\end{array}$ & $\begin{array}{l}\text { L200 + } \\
\text { R132 }\end{array}$ & $\begin{array}{c}1 / \\
147\end{array}$ \\
\hline & $"$ & 6 & $7^{\prime}$ & $\begin{array}{l}\text { S4 PAR MFL+7.5" } \\
\text { Barndoor } 575 w\end{array}$ & $"$ & $"$ & $"$ \\
\hline \multirow[t]{2}{*}{ (154) } & $\begin{array}{l}\text { 2nd } \\
\text { Electric DS }\end{array}$ & 1 & $23^{\prime}$ & S4 PAR MFL 575w & $\begin{array}{l}\text { Back in } \\
1\end{array}$ & $\begin{array}{l}\text { L200 + } \\
\text { R132 }\end{array}$ & $\begin{array}{c}1 / \\
139\end{array}$ \\
\hline & $"$ & 3 & $19^{\prime}$ & $"$ & $"$ & $"$ & $"$ \\
\hline \multirow[t]{2}{*}{ (155) } & $\begin{array}{l}\text { 2B Elec } \\
\text { LS\# } 21\end{array}$ & 16 & $-22 '-11^{\prime \prime}$ & $\begin{array}{l}\text { S4 PAR MFL+7.5" } \\
\text { Barndoor } 575 w\end{array}$ & $\begin{array}{l}\text { Back in } \\
2\end{array}$ & $\begin{array}{l}\text { L200 + } \\
\text { R132 }\end{array}$ & $\begin{array}{c}1 / \\
247\end{array}$ \\
\hline & $"$ & 17 & $-25^{\prime}-11^{\prime \prime}$ & S4 PAR MFL 575w & $"$ & $"$ & $"$ \\
\hline (156) & $\begin{array}{l}\text { 2B Elec } \\
\text { LS\# } 21\end{array}$ & 14 & $-18 '-11^{\prime \prime}$ & $\begin{array}{l}\text { S4 PAR MFL+7.5" } \\
\text { Barndoor } 575 \mathrm{w}\end{array}$ & $\begin{array}{l}\text { Back in } \\
2\end{array}$ & $\begin{array}{l}\text { L200 + } \\
\text { R132 }\end{array}$ & $\begin{array}{c}1 / \\
191\end{array}$ \\
\hline (157) & $\begin{array}{l}\text { 2B Elec } \\
\text { LS\# } 21\end{array}$ & 12 & $-13^{\prime}-11^{\prime \prime}$ & $\begin{array}{l}\text { S4 PAR MFL+7.5" } \\
\text { Barndoor } 575 w\end{array}$ & $\begin{array}{l}\text { Back in } \\
2\end{array}$ & $\begin{array}{l}\text { L200 + } \\
\text { R132 }\end{array}$ & $\begin{array}{c}1 / \\
241\end{array}$ \\
\hline (158) & $\begin{array}{l}\text { 2B Elec } \\
\text { LS\# } 21\end{array}$ & 7 & $14^{\prime}-1 "$ & $\begin{array}{l}\text { S4 PAR MFL+7.5" } \\
\text { Barndoor } 575 w\end{array}$ & $\begin{array}{l}\text { Back in } \\
2\end{array}$ & $\begin{array}{l}\text { L200 + } \\
\text { R132 }\end{array}$ & $\begin{array}{c}1 / \\
245\end{array}$ \\
\hline (159) & $\begin{array}{l}\text { 2B Elec } \\
\text { LS\# } 21\end{array}$ & 5 & $19^{\prime}-1 "$ & $\begin{array}{l}\text { S4 PAR MFL+7.5" } \\
\text { Barndoor } 575 w\end{array}$ & $\begin{array}{l}\text { Back in } \\
2\end{array}$ & $\begin{array}{l}\text { L200 + } \\
\text { R132 }\end{array}$ & $\begin{array}{c}1 / \\
237\end{array}$ \\
\hline \multirow[t]{2}{*}{ (160) } & $\begin{array}{l}\text { 2B Elec } \\
\text { LS\# } 21\end{array}$ & 2 & $26^{\prime}-1 "$ & S4 PAR MFL 575w & $\begin{array}{l}\text { Back in } \\
2\end{array}$ & $\begin{array}{l}\text { L200 + } \\
\text { R132 }\end{array}$ & $\begin{array}{c}1 / \\
193\end{array}$ \\
\hline & $"$ & 3 & $23^{\prime}-1 "$ & $\begin{array}{l}\text { S4 PAR MFL+7.5" } \\
\text { Barndoor } 575 w\end{array}$ & $"$ & $"$ & $"$ \\
\hline
\end{tabular}


The Magic Flute

Channel Hookup

Page 8 of 20

$4 / 17 / 19$

The Magic Flute load in.Iw6

\begin{tabular}{|c|c|c|c|c|c|c|c|}
\hline Channel & Position & U\# & XCoord & Type \& Acc \& Load & Purp & Clr \& Gbo & $\mathrm{Ad}$ \\
\hline \multirow[t]{2}{*}{ (161) } & $\begin{array}{l}\text { 3rd } \\
\text { Electric DS }\end{array}$ & 22 & $-20^{\prime}$ & S4 PAR MFL 575w & $\begin{array}{l}\text { Back in } \\
3\end{array}$ & $\begin{array}{l}\text { L200 + } \\
\text { R132 }\end{array}$ & $\begin{array}{c}1 / \\
184\end{array}$ \\
\hline & $"$ & 26 & $-24^{\prime}$ & $"$ & $"$ & $"$ & $"$ \\
\hline (162) & $\begin{array}{l}\text { 3rd } \\
\text { Electric DS }\end{array}$ & 17 & $-14^{\prime}$ & S4 PAR MFL 575w & $\begin{array}{l}\text { Back in } \\
3\end{array}$ & $\begin{array}{l}\mathrm{L} 200+ \\
\mathrm{R} 132\end{array}$ & $\begin{array}{c}11 \\
170\end{array}$ \\
\hline (163) & $\begin{array}{l}\text { 3rd } \\
\text { Electric DS }\end{array}$ & 10 & $14^{\prime}$ & S4 PAR MFL 575w & $\begin{array}{l}\text { Back in } \\
3\end{array}$ & $\begin{array}{l}\mathrm{L} 200+ \\
\mathrm{R} 132\end{array}$ & $\begin{array}{c}11 \\
163\end{array}$ \\
\hline \multirow[t]{2}{*}{ (164) } & $\begin{array}{l}\text { 3rd } \\
\text { Electric DS }\end{array}$ & 1 & $24^{\prime}$ & S4 PAR MFL 575w & $\begin{array}{l}\text { Back in } \\
3\end{array}$ & $\begin{array}{l}\mathrm{L} 200+ \\
\mathrm{R} 132\end{array}$ & $\begin{array}{c}1 / \\
173\end{array}$ \\
\hline & $"$ & 5 & $20^{\prime}$ & $"$ & $"$ & $"$ & $"$ \\
\hline (201) & $\begin{array}{l}\text { SR Boom } \\
1\end{array}$ & 3 & $121^{\prime}-5^{\prime \prime}$ & $\begin{array}{l}\text { Sixpar } 100+30 \text { deg. } \\
\text { lens } 89 w\end{array}$ & $\begin{array}{l}\text { LED Low } \\
\text { Side }\end{array}$ & R104? V? & $\begin{array}{l}4 / \\
31\end{array}$ \\
\hline (202) & $\begin{array}{l}\text { SR Boom } \\
1\end{array}$ & 2 & $121^{\prime}-5^{\prime \prime}$ & $\begin{array}{l}\text { Sixpar } 100+30 \text { deg. } \\
\text { lens } 89 w\end{array}$ & $\begin{array}{l}\text { LED Low } \\
\text { Side }\end{array}$ & R104? V? & $\begin{array}{l}4 \\
11 \\
\end{array}$ \\
\hline (203) & $\begin{array}{l}\text { SR Boom } \\
1\end{array}$ & 1 & 121'-6" & $\begin{array}{l}\text { Sixpar } 100+30 \text { deg. } \\
\text { lens } 89 w\end{array}$ & $\begin{array}{l}\text { LED Low } \\
\text { Side }\end{array}$ & R104? V? & $\begin{array}{c}4 / \\
1 \\
\end{array}$ \\
\hline (204) & $\begin{array}{l}\text { SR Boom } \\
2\end{array}$ & 3 & $124^{\prime}-11^{\prime \prime}$ & $\begin{array}{l}\text { Sixpar } 100+30 \text { deg. } \\
\text { lens } 89 w\end{array}$ & $\begin{array}{l}\text { LED Low } \\
\text { Side }\end{array}$ & R104? V? & $\begin{array}{l}4 / \\
61\end{array}$ \\
\hline (205) & $\begin{array}{l}\text { SR Boom } \\
2\end{array}$ & 2 & $124^{\prime}-11^{\prime \prime}$ & $\begin{array}{l}\text { Sixpar } 100+30 \text { deg. } \\
\text { lens } 89 w\end{array}$ & $\begin{array}{l}\text { LED Low } \\
\text { Side }\end{array}$ & R104? V? & $\begin{array}{l}4 / \\
51 \\
\end{array}$ \\
\hline (206) & $\begin{array}{l}\text { SR Boom } \\
2\end{array}$ & 1 & 124'-11" & $\begin{array}{l}\text { Sixpar } 100+30 \text { deg. } \\
\text { lens } 89 w\end{array}$ & $\begin{array}{l}\text { LED Low } \\
\text { Side }\end{array}$ & R104? V? & $\begin{array}{l}4 / \\
41 \\
\end{array}$ \\
\hline (207) & $\begin{array}{l}\text { SR Boom } \\
3\end{array}$ & 3 & $129^{\prime}$ & $\begin{array}{l}\text { Sixpar } 100+30 \text { deg. } \\
\text { lens } 89 w\end{array}$ & $\begin{array}{l}\text { LED Low } \\
\text { Side }\end{array}$ & R104? V? & $\begin{array}{l}4 / \\
91 \\
\end{array}$ \\
\hline (208) & $\begin{array}{l}\text { SR Boom } \\
3\end{array}$ & 2 & $129^{\prime}$ & $\begin{array}{l}\text { Sixpar } 100+30 \text { deg. } \\
\text { lens } 89 w\end{array}$ & $\begin{array}{l}\text { LED Low } \\
\text { Side }\end{array}$ & R104? V? & $\begin{array}{l}4 / \\
81\end{array}$ \\
\hline (209) & $\begin{array}{l}\text { SR Boom } \\
3\end{array}$ & 1 & $129^{\prime}$ & $\begin{array}{l}\text { Sixpar } 100+30 \text { deg. } \\
\text { lens } 89 w\end{array}$ & $\begin{array}{l}\text { LED Low } \\
\text { Side }\end{array}$ & R104? V? & $\begin{array}{l}4 / \\
71\end{array}$ \\
\hline (210) & $\begin{array}{l}\text { SR Boom } \\
4\end{array}$ & 3 & $132^{\prime}-6^{\prime \prime}$ & $\begin{array}{l}\text { Sixpar } 100+30 \text { deg. } \\
\text { lens } 89 w\end{array}$ & $\begin{array}{l}\text { LED Low } \\
\text { Side }\end{array}$ & R104? V? & $\begin{array}{r}4 / 4 \\
121\end{array}$ \\
\hline (211) & $\begin{array}{l}\text { SR Boom } \\
4\end{array}$ & 2 & $132^{\prime}-6 "$ & $\begin{array}{l}\text { Sixpar } 100+30 \text { deg. } \\
\text { lens } 89 w\end{array}$ & $\begin{array}{l}\text { LED Low } \\
\text { Side }\end{array}$ & R104? V? & $\begin{array}{c}4 / \\
111\end{array}$ \\
\hline
\end{tabular}

Justin Burns / Lightwright 6

(161) thru (211) 
The Magic Flute load in.Iw6

\begin{tabular}{|c|c|c|c|c|c|c|c|}
\hline Channel & Position & U\# & XCoord & Type \& Acc \& Load & Purp & Clr \& Gbo & $\mathrm{Ad}$ \\
\hline (212) & $\begin{array}{l}\text { SR Boom } \\
4\end{array}$ & 1 & $132^{\prime}-6^{\prime \prime}$ & $\begin{array}{l}\text { Sixpar } 100+30 \text { deg. } \\
\text { lens } 89 w\end{array}$ & $\begin{array}{l}\text { LED Low } \\
\text { Side }\end{array}$ & R104? V? & $\begin{array}{c}4 / \\
101\end{array}$ \\
\hline (221) & $\begin{array}{l}\text { SL Boom } \\
1\end{array}$ & 3 & $93^{\prime}-5 "$ & $\begin{array}{l}\text { Sixpar } 100+30 \text { deg. } \\
\text { lens } 89 w\end{array}$ & $\begin{array}{l}\text { LED Low } \\
\text { Side }\end{array}$ & R104? V? & $\begin{array}{l}2 / \\
21\end{array}$ \\
\hline (222) & $\begin{array}{l}\text { SL Boom } \\
1\end{array}$ & 2 & $93^{\prime}-5 "$ & $\begin{array}{l}\text { Sixpar } 100+30 \text { deg. } \\
\text { lens } 89 w\end{array}$ & $\begin{array}{l}\text { LED Low } \\
\text { Side }\end{array}$ & R104? V? & $\begin{array}{l}2 / \\
11\end{array}$ \\
\hline (223) & $\begin{array}{l}\text { SL Boom } \\
1\end{array}$ & 1 & $93 '-6 "$ & $\begin{array}{l}\text { Sixpar } 100+30 \text { deg. } \\
\text { lens } 89 w\end{array}$ & $\begin{array}{l}\text { LED Low } \\
\text { Side }\end{array}$ & R104? V? & $\begin{array}{c}2 / \\
1\end{array}$ \\
\hline (224) & $\begin{array}{l}\text { SL Boom } \\
2\end{array}$ & 3 & 97'-7" & $\begin{array}{l}\text { Sixpar } 100+30 \text { deg. } \\
\text { lens } 89 w\end{array}$ & $\begin{array}{l}\text { LED Low } \\
\text { Side }\end{array}$ & R104? V? & $\begin{array}{l}21 \\
91\end{array}$ \\
\hline (225) & $\begin{array}{l}\text { SL Boom } \\
2\end{array}$ & 2 & $97^{\prime}-7^{\prime \prime}$ & $\begin{array}{l}\text { Sixpar } 100+30 \text { deg. } \\
\text { lens } 89 w\end{array}$ & $\begin{array}{l}\text { LED Low } \\
\text { Side }\end{array}$ & R104? V? & $\begin{array}{l}2 / \\
81\end{array}$ \\
\hline (226) & $\begin{array}{l}\text { SL Boom } \\
2\end{array}$ & 1 & 97'-7" & $\begin{array}{l}\text { Sixpar } 100+30 \text { deg. } \\
\text { lens } 89 w\end{array}$ & $\begin{array}{l}\text { LED Low } \\
\text { Side }\end{array}$ & R104? V? & $\begin{array}{l}2 / \\
71\end{array}$ \\
\hline (227) & $\begin{array}{l}\text { SL Boom } \\
3\end{array}$ & 3 & $101^{\prime}-9 "$ & $\begin{array}{l}\text { Sixpar } 100+30 \text { deg. } \\
\text { lens } 89 w\end{array}$ & $\begin{array}{l}\text { LED Low } \\
\text { Side }\end{array}$ & R104? V? & $\begin{array}{r}21 \\
331\end{array}$ \\
\hline (228) & $\begin{array}{l}\text { SL Boom } \\
3\end{array}$ & 2 & 101'-9" & $\begin{array}{l}\text { Sixpar } 100+30 \text { deg. } \\
\text { lens } 89 w\end{array}$ & $\begin{array}{l}\text { LED Low } \\
\text { Side }\end{array}$ & R104? V? & $\begin{array}{c}2 / \\
321\end{array}$ \\
\hline (229) & $\begin{array}{l}\text { SL Boom } \\
3\end{array}$ & 1 & 101'-9" & $\begin{array}{l}\text { Sixpar } 100+30 \text { deg. } \\
\text { lens } 89 w\end{array}$ & $\begin{array}{l}\text { LED Low } \\
\text { Side }\end{array}$ & R104? V? & $\begin{array}{c}21 \\
311\end{array}$ \\
\hline (230) & $\begin{array}{l}\text { SL Boom } \\
4\end{array}$ & 3 & $105^{\prime}-6 "$ & $\begin{array}{l}\text { Sixpar } 100+30 \text { deg. } \\
\text { lens } 89 w\end{array}$ & $\begin{array}{l}\text { LED Low } \\
\text { Side }\end{array}$ & R104? V? & $\begin{array}{c}21 \\
401\end{array}$ \\
\hline (231) & $\begin{array}{l}\text { SL Boom } \\
4\end{array}$ & 2 & $105^{\prime}-6 "$ & $\begin{array}{l}\text { Sixpar } 100+30 \text { deg. } \\
\text { lens } 89 w\end{array}$ & $\begin{array}{l}\text { LED Low } \\
\text { Side }\end{array}$ & R104? V? & $\begin{array}{c}21 \\
391\end{array}$ \\
\hline (232) & $\begin{array}{l}\text { SL Boom } \\
4\end{array}$ & 1 & $105^{\prime}-6 "$ & $\begin{array}{l}\text { Sixpar } 100+30 \text { deg. } \\
\text { lens } 89 w\end{array}$ & $\begin{array}{l}\text { LED Low } \\
\text { Side }\end{array}$ & R104? V? & $\begin{array}{c}21 \\
381\end{array}$ \\
\hline \multirow[t]{2}{*}{ (241) } & $\begin{array}{l}\text { SR Boom } \\
1\end{array}$ & $1 a$ & $120^{\prime}-6 "$ & Source 4 36deg & $\begin{array}{l}\text { Warm } \\
\text { Low > }\end{array}$ & $\begin{array}{l}\text { R08 + } \\
\text { R132 }\end{array}$ & $\begin{array}{c}1 / \\
136\end{array}$ \\
\hline & $"$ & $3 a$ & $"$ & $"$ & $"$ & $"$ & $"$ \\
\hline \multirow[t]{2}{*}{ (242) } & $\begin{array}{l}\text { SR Boom } \\
2\end{array}$ & $1 a$ & $124^{\prime}$ & Source 4 36deg & $\begin{array}{l}\text { Warm } \\
\text { Low > }\end{array}$ & $\begin{array}{l}\text { R08 + } \\
\text { R132 }\end{array}$ & $\begin{array}{c}1 / \\
190\end{array}$ \\
\hline & $"$ & $3 a$ & $"$ & $"$ & " & $"$ & $"$ \\
\hline
\end{tabular}


The Magic Flute

Channel Hookup

Page 10 of 20

$4 / 17 / 19$

The Magic Flute load in.Iw6

\begin{tabular}{|c|c|c|c|c|c|c|c|}
\hline Channel & Position & U\# & XCoord & Type \& Acc \& Load & Purp & Clr \& Gbo & $\mathrm{Ad}$ \\
\hline \multirow[t]{2}{*}{ (243) } & $\begin{array}{l}\text { SR Boom } \\
3\end{array}$ & $1 a$ & $128 '-1 "$ & Source 4 36deg & $\begin{array}{l}\text { Warm } \\
\text { Low > }\end{array}$ & $\begin{array}{l}\text { R08 + } \\
\text { R132 }\end{array}$ & $\begin{array}{c}1 / \\
156\end{array}$ \\
\hline & $"$ & $3 a$ & $"$ & $"$ & $"$ & $"$ & $"$ \\
\hline \multirow[t]{2}{*}{ (244) } & $\begin{array}{l}\text { SR Boom } \\
4\end{array}$ & $1 a$ & $131 '-6 "$ & Source 4 36deg & $\begin{array}{l}\text { Warm } \\
\text { Low > }\end{array}$ & $\begin{array}{l}\text { R08 + } \\
\text { R132 }\end{array}$ & $\begin{array}{c}1 / \\
242\end{array}$ \\
\hline & $"$ & 3a & $"$ & $"$ & $"$ & $"$ & $"$ \\
\hline \multirow[t]{2}{*}{ (245) } & $\begin{array}{l}\text { SL Boom } \\
1\end{array}$ & $1 a$ & $92^{\prime}-6^{\prime \prime}$ & Source 4 36deg & $\begin{array}{l}\text { Warm } \\
\text { Low < }\end{array}$ & $\begin{array}{l}\text { G360 + } \\
\text { R132 }\end{array}$ & $\begin{array}{c}1 / \\
133\end{array}$ \\
\hline & $"$ & $3 a$ & $"$ & $"$ & " & $"$ & $"$ \\
\hline \multirow[t]{2}{*}{ (246) } & $\begin{array}{l}\text { SL Boom } \\
2\end{array}$ & $1 a$ & $96^{\prime}-8^{\prime \prime}$ & Source 4 36deg & $\begin{array}{l}\text { Warm } \\
\text { Low < }\end{array}$ & $\begin{array}{l}\text { G360 + } \\
\text { R132 }\end{array}$ & $\begin{array}{c}1 / \\
199\end{array}$ \\
\hline & $"$ & $3 a$ & $"$ & $"$ & $"$ & $"$ & " \\
\hline \multirow[t]{2}{*}{ (247) } & $\begin{array}{l}\text { SL Boom } \\
3\end{array}$ & $1 a$ & $100^{\prime}-10^{\prime \prime}$ & Source 4 36deg & $\begin{array}{l}\text { Warm } \\
\text { Low < }\end{array}$ & $\begin{array}{l}\text { G360 + } \\
\text { R132 }\end{array}$ & $\begin{array}{c}1 / \\
157\end{array}$ \\
\hline & $"$ & $3 a$ & $"$ & $"$ & $"$ & $"$ & $"$ \\
\hline \multirow[t]{2}{*}{ (248) } & $\begin{array}{l}\text { SL Boom } \\
4\end{array}$ & $1 a$ & 104'-7" & Source 4 36deg & $\begin{array}{l}\text { Warm } \\
\text { Low < }\end{array}$ & $\begin{array}{l}\text { G360 + } \\
\text { R132 }\end{array}$ & $\begin{array}{c}3 / \\
501\end{array}$ \\
\hline & $"$ & $3 a$ & $"$ & $"$ & $"$ & $"$ & $"$ \\
\hline \multirow[t]{2}{*}{ (251) } & $\begin{array}{l}\text { SR Boom } \\
1\end{array}$ & $1 b$ & $122^{\prime}-4^{\prime \prime}$ & Source 4 36deg & $\begin{array}{l}\text { Cool } \\
\text { Low > }\end{array}$ & $\begin{array}{l}\text { G842 + } \\
\text { R132 }\end{array}$ & $\begin{array}{l}1 / \\
130\end{array}$ \\
\hline & $"$ & $3 \mathrm{~b}$ & $"$ & $"$ & $"$ & $"$ & $"$ \\
\hline \multirow[t]{2}{*}{ (252) } & $\begin{array}{l}\text { SR Boom } \\
2\end{array}$ & $1 \mathrm{~b}$ & $125^{\prime}-9^{\prime \prime}$ & Source 4 36deg & $\begin{array}{l}\text { Cool } \\
\text { Low > }\end{array}$ & $\begin{array}{l}\text { G842 + } \\
\text { R132 }\end{array}$ & $\begin{array}{c}1 / \\
188\end{array}$ \\
\hline & $"$ & $3 b$ & $"$ & $"$ & $"$ & $"$ & $"$ \\
\hline \multirow[t]{2}{*}{ (253) } & $\begin{array}{l}\text { SR Boom } \\
3\end{array}$ & $1 \mathrm{~b}$ & 129'-10" & Source 4 36deg & $\begin{array}{l}\text { Cool } \\
\text { Low > }\end{array}$ & $\begin{array}{l}\text { G842 + } \\
\text { R132 }\end{array}$ & $\begin{array}{c}1 / \\
154\end{array}$ \\
\hline & $"$ & $3 b$ & $"$ & $"$ & $"$ & $"$ & $"$ \\
\hline \multirow[t]{2}{*}{ (254) } & $\begin{array}{l}\text { SR Boom } \\
4\end{array}$ & $1 b$ & $133^{\prime}-4^{\prime \prime}$ & Source 4 36deg & $\begin{array}{l}\text { Cool } \\
\text { Low > }\end{array}$ & $\begin{array}{l}\text { G842 + } \\
\text { R132 }\end{array}$ & $\begin{array}{l}1 / \\
238\end{array}$ \\
\hline & $"$ & $3 \mathrm{~b}$ & $"$ & $"$ & $"$ & $"$ & $"$ \\
\hline
\end{tabular}

Justin Burns / Lightwright 6

(243) thru (254) 
The Magic Flute load in.Iw6

\begin{tabular}{|c|c|c|c|c|c|c|c|}
\hline Channel & Position & U\# & XCoord & Type \& Acc \& Load & Purp & Clr \& Gbo & $\mathrm{Ad}$ \\
\hline \multirow[t]{2}{*}{ (255) } & $\begin{array}{l}\text { SL Boom } \\
1\end{array}$ & $1 b$ & $94^{\prime}-4^{\prime \prime}$ & Source 4 36deg & $\begin{array}{l}\text { Cool } \\
\text { Low }<\end{array}$ & $\begin{array}{l}\text { R65 + } \\
\text { R132 }\end{array}$ & $\begin{array}{c}1 / \\
135\end{array}$ \\
\hline & $"$ & $3 b$ & $"$ & $"$ & $"$ & $"$ & $"$ \\
\hline \multirow[t]{2}{*}{ (256) } & $\begin{array}{l}\text { SL Boom } \\
2\end{array}$ & $1 b$ & $98 '-5 "$ & Source 4 36deg & $\begin{array}{l}\text { Cool } \\
\text { Low }<\end{array}$ & $\begin{array}{l}\text { R65 + } \\
\text { R132 }\end{array}$ & $\begin{array}{c}1 / \\
185\end{array}$ \\
\hline & $"$ & $3 b$ & $"$ & $"$ & $"$ & $"$ & $"$ \\
\hline \multirow[t]{2}{*}{ (257) } & $\begin{array}{l}\text { SL Boom } \\
3\end{array}$ & $1 b$ & $102 '-7 "$ & Source 4 36deg & $\begin{array}{l}\text { Cool } \\
\text { Low }<\end{array}$ & $\begin{array}{l}\text { R65 + } \\
\text { R132 }\end{array}$ & $\begin{array}{c}1 / \\
155\end{array}$ \\
\hline & $"$ & $3 b$ & $"$ & $"$ & $"$ & $"$ & $"$ \\
\hline \multirow[t]{2}{*}{ (258) } & $\begin{array}{l}\text { SL Boom } \\
4\end{array}$ & $1 b$ & $106 '-4 "$ & Source 4 36deg & $\begin{array}{l}\text { Cool } \\
\text { Low }<\end{array}$ & $\begin{array}{l}\text { R65 + } \\
\text { R132 }\end{array}$ & $\begin{array}{c}3 / \\
502\end{array}$ \\
\hline & $"$ & $3 b$ & $"$ & $"$ & $"$ & $"$ & $"$ \\
\hline (261) & $\begin{array}{l}\text { SR Boom } \\
1\end{array}$ & $2 b$ & $122^{\prime}-4^{\prime \prime}$ & $\begin{array}{l}\text { ETC Source4 50deg } \\
750750 w\end{array}$ & $\begin{array}{l}\text { Linear } \\
\text { Temp > }\end{array}$ & $\begin{array}{l}\text { N/C, T: } \\
\text { R77216 }\end{array}$ & $\begin{array}{c}1 / \\
128\end{array}$ \\
\hline (262) & $\begin{array}{l}\text { SR Boom } \\
2\end{array}$ & $2 b$ & $125^{\prime}-9^{\prime \prime}$ & $\begin{array}{l}\text { ETC Source4 50deg } \\
750750 w\end{array}$ & $\begin{array}{l}\text { Linear } \\
\text { Temp }>\end{array}$ & $\begin{array}{l}\text { N/C, T: } \\
\text { R77216 }\end{array}$ & $\begin{array}{c}1 / \\
192\end{array}$ \\
\hline (263) & $\begin{array}{l}\text { SR Boom } \\
3\end{array}$ & $2 b$ & 129'-10" & $\begin{array}{l}\text { ETC Source4 50deg } \\
750750 w\end{array}$ & $\begin{array}{l}\text { Linear } \\
\text { Temp > }\end{array}$ & $\begin{array}{l}\text { N/C, T: } \\
\text { R77216 }\end{array}$ & $\begin{array}{c}1 / \\
158\end{array}$ \\
\hline (264) & $\begin{array}{l}\text { SR Boom } \\
4\end{array}$ & $2 b$ & $133^{\prime}-4^{\prime \prime}$ & $\begin{array}{l}\text { ETC Source4 50deg } \\
750750 w\end{array}$ & $\begin{array}{l}\text { Linear } \\
\text { Temp }>\end{array}$ & $\begin{array}{l}\text { N/C, T: } \\
\text { R77216 }\end{array}$ & $\begin{array}{c}1 / \\
240\end{array}$ \\
\hline (265) & $\begin{array}{l}\text { SL Boom } \\
1\end{array}$ & $2 b$ & $94 '-4 "$ & $\begin{array}{l}\text { ETC Source4 50deg } \\
750750 w\end{array}$ & $\begin{array}{l}\text { Linear } \\
\text { Temp }<\end{array}$ & $\begin{array}{l}\text { N/C, T: } \\
\text { R77216 }\end{array}$ & $\begin{array}{c}1 / \\
131\end{array}$ \\
\hline (266) & $\begin{array}{l}\text { SL Boom } \\
2\end{array}$ & $2 b$ & $98^{\prime}-5^{\prime \prime}$ & $\begin{array}{l}\text { ETC Source4 50deg } \\
750750 w\end{array}$ & $\begin{array}{l}\text { Linear } \\
\text { Temp }<\end{array}$ & $\begin{array}{l}N / C, T: \\
R 77216\end{array}$ & $\begin{array}{c}1 / \\
189\end{array}$ \\
\hline (267) & $\begin{array}{l}\text { SL Boom } \\
3\end{array}$ & $2 b$ & $102^{\prime}-7^{\prime \prime}$ & $\begin{array}{l}\text { ETC Source4 50deg } \\
750750 w\end{array}$ & $\begin{array}{l}\text { Linear } \\
\text { Temp }<\end{array}$ & $\begin{array}{l}\mathrm{N} / \mathrm{C}, \mathrm{T} \\
\mathrm{R} 77216\end{array}$ & $\begin{array}{c}1 / \\
153\end{array}$ \\
\hline (268) & $\begin{array}{l}\text { SL Boom } \\
4\end{array}$ & $2 b$ & $106^{\prime}-4^{\prime \prime}$ & $\begin{array}{l}\text { ETC Source4 50deg } \\
750750 w\end{array}$ & $\begin{array}{l}\text { Linear } \\
\text { Temp }<\end{array}$ & $\begin{array}{l}\text { N/C, T: } \\
\text { R77216 }\end{array}$ & $\begin{array}{c}31 \\
503\end{array}$ \\
\hline (271) & $\begin{array}{l}\text { SR Boom } \\
1\end{array}$ & $2 a$ & $120^{\prime}-6^{\prime \prime}$ & Source 4 36deg & $\begin{array}{l}\text { Organic } \\
\text { Temp > }\end{array}$ & $\begin{array}{l}\text { L203, T: } \\
\text { R77735 }\end{array}$ & $\begin{array}{c}1 / \\
132\end{array}$ \\
\hline (272) & $\begin{array}{l}\text { SR Boom } \\
2\end{array}$ & $2 a$ & $124^{\prime}$ & Source 4 36deg & $\begin{array}{l}\text { Organic } \\
\text { Temp > }\end{array}$ & $\begin{array}{l}\text { L203, T: } \\
\text { R77735 }\end{array}$ & $\begin{array}{c}1 / \\
194\end{array}$ \\
\hline
\end{tabular}


The Magic Flute load in.Iw6

\begin{tabular}{|c|c|c|c|c|c|c|c|}
\hline Channel & Position & U\# & XCoord & Type \& Acc \& Load & Purp & Clr \& Gbo & $\mathrm{Ad}$ \\
\hline (273) & $\begin{array}{l}\text { SR Boom } \\
3\end{array}$ & $2 a$ & $128^{\prime}-1^{\prime \prime}$ & Source 4 36deg & $\begin{array}{l}\text { Organic } \\
\text { Temp > }\end{array}$ & $\begin{array}{l}\text { Q203, T: } \\
\text { R77735 }\end{array}$ & $\begin{array}{c}1 / \\
160\end{array}$ \\
\hline (274) & $\begin{array}{l}\text { SR Boom } \\
4\end{array}$ & $2 a$ & $131^{\prime}-6^{\prime \prime}$ & Source 4 36deg & $\begin{array}{l}\text { Organic } \\
\text { Temp > }\end{array}$ & $\begin{array}{l}\text { O } \\
\text { R777735 }\end{array}$ & $\begin{array}{c}11 \\
244\end{array}$ \\
\hline (275) & $\begin{array}{l}\text { SL Boom } \\
1\end{array}$ & $2 a$ & $92^{\prime}-6^{\prime \prime}$ & Source 4 36deg & $\begin{array}{l}\text { Organic } \\
\text { Temp }<\end{array}$ & $\begin{array}{l}\text { Q } \\
\text { L203, T: } \\
\text { R77735 }\end{array}$ & $\begin{array}{c}1 / \\
129\end{array}$ \\
\hline (276) & $\begin{array}{l}\text { SL Boom } \\
2\end{array}$ & $2 a$ & $96 '-8 "$ & Source 4 36deg & $\begin{array}{l}\text { Organic } \\
\text { Temp < }\end{array}$ & $\begin{array}{l}\text { L203, T: } \\
\text { R77735 }\end{array}$ & $\begin{array}{c}1 / \\
260\end{array}$ \\
\hline (277) & $\begin{array}{l}\text { SL Boom } \\
3\end{array}$ & $2 a$ & $100^{\prime}-10^{\prime \prime}$ & Source 4 36deg & $\begin{array}{l}\text { Organic } \\
\text { Temp }<\end{array}$ & $\begin{array}{l}\text { L203, T: } \\
\text { R77735 }\end{array}$ & $\begin{array}{c}1 / \\
159\end{array}$ \\
\hline (278) & $\begin{array}{l}\text { SL Boom } \\
4\end{array}$ & $2 a$ & $104^{\prime}-7 "$ & Source 4 36deg & $\begin{array}{l}\text { Organic } \\
\text { Temp }<\end{array}$ & $\begin{array}{l}\text { L203, T: } \\
\text { R777335 }\end{array}$ & $\begin{array}{c}31 \\
504\end{array}$ \\
\hline (281) & SR Port & 12 & $-32^{\prime}-11 "$ & $\begin{array}{l}\text { Source } 436 \mathrm{deg}+6.25 " \\
\text { Tophat } 575 \mathrm{w}\end{array}$ & $\begin{array}{l}\text { SR Box } \\
\text { Boom }\end{array}$ & $\begin{array}{l}\text { (3) } R 316 \text {, } \\
T: G 622\end{array}$ & $\begin{array}{l}1 / \\
39\end{array}$ \\
\hline (282) & SR Port & 11 & $-31^{\prime}$ & $\begin{array}{l}\text { Source } 436 \mathrm{deg}+6.25 " \\
\text { Tophat } 575 \mathrm{w}\end{array}$ & $\begin{array}{l}\text { SR Box } \\
\text { Boom }\end{array}$ & $\begin{array}{l}\text { (2) } \mathrm{R} 316 \text {, } \\
\mathrm{T}: \mathrm{G} 622\end{array}$ & $\begin{array}{l}1 / \\
37\end{array}$ \\
\hline (283) & SR Port & 10 & $-32 '-11 "$ & $\begin{array}{l}\text { Source } 436 \mathrm{deg}+6.25 " \\
\text { Tophat } 575 \mathrm{w}\end{array}$ & $\begin{array}{l}\text { SR Box } \\
\text { Boom }\end{array}$ & $\begin{array}{l}\text { (2.) } \mathrm{R} 316 \text {, } \\
\mathrm{T}: \mathrm{G} 622\end{array}$ & $\begin{array}{l}1 / \\
35\end{array}$ \\
\hline (284) & SR Port & 9 & $-31^{\prime}$ & $\begin{array}{l}\text { Source } 436 \mathrm{deg}+6.25 " \\
\text { Tophat } 575 \mathrm{w}\end{array}$ & $\begin{array}{l}\text { SR Box } \\
\text { Boom }\end{array}$ & 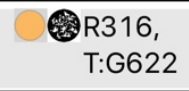 & $\begin{array}{l}1 / \\
33\end{array}$ \\
\hline (285) & SR Port & 8 & $-32^{\prime}-10^{\prime \prime}$ & $\begin{array}{l}\text { Source } 426 \mathrm{deg}+6.25 \text { " } \\
\text { Tophat } 575 \mathrm{w}\end{array}$ & $\begin{array}{l}\text { SR Box } \\
\text { Boom }\end{array}$ & $\begin{array}{l}\text { (1) } \mathrm{R} 316, \\
\mathrm{~T}: \mathrm{G} 622\end{array}$ & $\begin{array}{l}1 / \\
31\end{array}$ \\
\hline (286) & SR Port & 7 & $-30^{\prime}-11^{\prime \prime}$ & $\begin{array}{l}\text { Source } 426 \mathrm{deg}+6.25 \\
\text { Tophat } 575 \mathrm{w}\end{array}$ & $\begin{array}{l}\text { SR Box } \\
\text { Boom }\end{array}$ & $\begin{array}{l}\text { (2) } \mathrm{R} 316 \text {, } \\
\mathrm{T}: \mathrm{G} 622\end{array}$ & $\begin{array}{l}1 / \\
29\end{array}$ \\
\hline (287) & SR Port & 6 & $-32 '-11^{\prime \prime}$ & $\begin{array}{l}\text { Source } 426 \mathrm{deg}+6.25 \text { " } \\
\text { Tophat } 575 \mathrm{w}\end{array}$ & $\begin{array}{l}\text { SR Box } \\
\text { Boom }\end{array}$ & $\begin{array}{l}\text { (2) R316, } \\
\mathrm{T}: \mathrm{G} 622\end{array}$ & $\begin{array}{l}1 / \\
27\end{array}$ \\
\hline (288) & SR Port & 5 & $-31^{\prime}$ & $\begin{array}{l}\text { Source } 426 \mathrm{deg}+6.25 " \\
\text { Tophat } 575 \mathrm{w}\end{array}$ & $\begin{array}{l}\text { SR Box } \\
\text { Boom }\end{array}$ & $\begin{array}{l}\text { (2. } \mathrm{R} 316 \text {, } \\
\mathrm{T}: \mathrm{G} 622\end{array}$ & $\begin{array}{l}1 / \\
25\end{array}$ \\
\hline (289) & $\begin{array}{l}\text { 1st } \\
\text { Electric DS }\end{array}$ & 10 & $-24^{\prime}-6^{\prime \prime}$ & $\begin{array}{l}\text { ETC Source4 50deg } \\
750750 \mathrm{w}\end{array}$ & $\begin{array}{l}\text { SR Box } \\
\text { Boom }\end{array}$ & $\begin{array}{l}\text { (20) } \mathrm{R} 316 \text {, } \\
\mathrm{T}: \mathrm{G} 622\end{array}$ & $\begin{array}{c}1 / \\
134\end{array}$ \\
\hline (291) & SL Port & 12 & $32^{\prime}-11^{\prime \prime}$ & $\begin{array}{l}\text { Source } 436 \mathrm{deg}+6.25 \text { " } \\
\text { Tophat } 575 w\end{array}$ & $\begin{array}{l}\text { SL Box } \\
\text { Boom }\end{array}$ & $\begin{array}{l}R 58, T: \\
R 77805\end{array}$ & $\begin{array}{l}1 / \\
40\end{array}$ \\
\hline
\end{tabular}


The Magic Flute load in.Iw6

\begin{tabular}{|c|c|c|c|c|c|c|c|}
\hline Channel & Position & U\# & XCoord & Type \& Acc \& Load & Purp & Clr \& Gbo & $\mathrm{Ad}$ \\
\hline (292) & SL Port & 11 & $30 '-11^{\prime \prime}$ & $\begin{array}{l}\text { Source } 436 \mathrm{deg}+6.25 " \\
\text { Tophat } 575 w\end{array}$ & $\begin{array}{l}\text { SL Box } \\
\text { Boom }\end{array}$ & $\begin{array}{l}R 58, T: \\
R 77805\end{array}$ & $\begin{array}{l}1 / \\
38\end{array}$ \\
\hline (293) & SL Port & 10 & $32^{\prime}-11^{\prime \prime}$ & $\begin{array}{l}\text { Source } 436 \mathrm{deg}+6.25 " \\
\text { Tophat } 575 w\end{array}$ & $\begin{array}{l}\text { SL Box } \\
\text { Boom }\end{array}$ & $\begin{array}{l}R 58, T: \\
R 77805\end{array}$ & $\begin{array}{l}1 / \\
36\end{array}$ \\
\hline (294) & SL Port & 9 & $31^{\prime}$ & $\begin{array}{l}\text { Source } 436 \mathrm{deg}+6.25 " \\
\text { Tophat } 575 \mathrm{w}\end{array}$ & $\begin{array}{l}\text { SL Box } \\
\text { Boom }\end{array}$ & $\begin{array}{l}\text { R58, T: } \\
\text { R77805 }\end{array}$ & $\begin{array}{l}1 / \\
34\end{array}$ \\
\hline (295) & SL Port & 8 & $32^{\prime}-10^{\prime \prime}$ & $\begin{array}{l}\text { Source } 426 \mathrm{deg}+6.25 " \\
\text { Tophat } 575 \mathrm{w}\end{array}$ & $\begin{array}{l}\text { SL Box } \\
\text { Boom }\end{array}$ & $\begin{array}{l}R 58, T: \\
R 77805\end{array}$ & $\begin{array}{l}1 / \\
32\end{array}$ \\
\hline (296) & SL Port & 7 & $30 '-11^{\prime \prime}$ & $\begin{array}{l}\text { Source } 426 \mathrm{deg}+6.25 " \\
\text { Tophat } 575 \mathrm{w}\end{array}$ & $\begin{array}{l}\text { SL Box } \\
\text { Boom }\end{array}$ & $\begin{array}{l}\text { R58, T: } \\
\text { R77805 }\end{array}$ & $\begin{array}{l}1 / \\
30\end{array}$ \\
\hline (297) & SL Port & 6 & $32^{\prime}-11^{\prime \prime}$ & $\begin{array}{l}\text { Source } 426 \mathrm{deg}+6.25 " \\
\text { Tophat } 575 \mathrm{w}\end{array}$ & $\begin{array}{l}\text { SL Box } \\
\text { Boom }\end{array}$ & $\begin{array}{l}\mathrm{R} 58, \mathrm{~T}: \\
\mathrm{R} 77805\end{array}$ & $\begin{array}{l}1 / \\
28\end{array}$ \\
\hline (298) & SL Port & 5 & $31^{\prime}$ & $\begin{array}{l}\text { Source } 426 \mathrm{deg}+6.25 " \\
\text { Tophat } 575 \mathrm{w}\end{array}$ & $\begin{array}{l}\text { SL Box } \\
\text { Boom }\end{array}$ & $\begin{array}{l}R 58, T: \\
R 77805\end{array}$ & $\begin{array}{l}1 / \\
26\end{array}$ \\
\hline (299) & $\begin{array}{l}1 \text { st } \\
\text { Electric DS }\end{array}$ & 1 & $24^{\prime}-6^{\prime \prime}$ & $\begin{array}{l}\text { ETC Source4 50deg } \\
750750 w\end{array}$ & $\begin{array}{l}\text { SL Box } \\
\text { Boom }\end{array}$ & $\begin{array}{l}R 58, T: \\
R 77805\end{array}$ & $\begin{array}{c}1 / \\
107\end{array}$ \\
\hline (301) & $\begin{array}{l}\text { 1B Elec } \\
\text { LS\# } 5\end{array}$ & 13 & $-14^{\prime}$ & $\begin{array}{l}\text { Sixpar } 100+7.5 " \text { Tophat } \\
89 w\end{array}$ & $\begin{array}{l}\text { Scrim } \\
\text { Color }\end{array}$ & R104 & $\begin{array}{c}21 \\
291\end{array}$ \\
\hline (302) & $\begin{array}{l}\text { 1B Elec } \\
\text { LS\# } 5\end{array}$ & 10 & $-7^{\prime}$ & $\begin{array}{l}\text { Sixpar } 100+7.5 " \text { Tophat } \\
89 w\end{array}$ & $\begin{array}{l}\text { Scrim } \\
\text { Color }\end{array}$ & R104 & $\begin{array}{c}21 \\
241\end{array}$ \\
\hline (303) & $\begin{array}{l}\text { 1B Elec } \\
\text { LS\# } 5\end{array}$ & 6 & $7^{\prime}$ & $\begin{array}{l}\text { Sixpar } 100+7.5^{\prime \prime} \text { Tophat } \\
89 \mathrm{w}\end{array}$ & $\begin{array}{l}\text { Scrim } \\
\text { Color }\end{array}$ & R104 & $\begin{array}{c}21 \\
151\end{array}$ \\
\hline (304) & $\begin{array}{l}\text { 1B Elec } \\
\text { LS\# } 5\end{array}$ & 3 & 0'-1" & $\begin{array}{l}\text { Sixpar } 100+7.5 " \text { Tophat } \\
89 w\end{array}$ & $\begin{array}{l}\text { Scrim } \\
\text { Color }\end{array}$ & R104 & $\begin{array}{c}21 \\
101\end{array}$ \\
\hline \multirow[t]{4}{*}{ (305) } & $\begin{array}{l}\text { 1B Elec } \\
\text { LS\# } 5\end{array}$ & 1 & $26^{\prime}$ & Source 4 26deg $575 \mathrm{w}$ & $\begin{array}{l}\text { Scrim Cool } \\
\text { Streaks }\end{array}$ & $\begin{array}{l}\text { R73, } T: \\
R 77728\end{array}$ & $\begin{array}{l}5 / \\
12\end{array}$ \\
\hline & $"$ & 2 & $24^{\prime}$ & $"$ & $"$ & $"$ & $"$ \\
\hline & $"$ & 14 & $-24^{\prime}$ & $"$ & " & $"$ & " \\
\hline & $"$ & 15 & $-26^{\prime}$ & $"$ & $"$ & $"$ & $"$ \\
\hline
\end{tabular}


The Magic Flute load in.Iw6

\begin{tabular}{|c|c|c|c|c|c|c|c|}
\hline Channel & Position & U\# & XCoord & Type \& Acc \& Load & Purp & Clr \& Gbo & $\mathrm{Ad}$ \\
\hline \multirow[t]{4}{*}{ (306) } & $\begin{array}{l}\text { 1B Elec } \\
\text { LS\# } 5\end{array}$ & 5 & 8'-6" & Source 4 26deg $575 w$ & $\begin{array}{l}\text { Scrim } \\
\text { Warm } \\
\text { Bursts }\end{array}$ & $\begin{array}{l}\text { R18, } \mathrm{T}: \\
\mathrm{R} 78084\end{array}$ & $\begin{array}{l}5 / \\
11\end{array}$ \\
\hline & $"$ & 7 & 5'-6" & $"$ & $"$ & $"$ & $"$ \\
\hline & $"$ & 9 & $-5^{\prime}-6^{\prime \prime}$ & $"$ & $"$ & $"$ & $"$ \\
\hline & " & 11 & $-8^{\prime}-6^{\prime \prime}$ & ". & "\%" & " & " \\
\hline (311) & Set & & $108 '-2 "$ & Sixpar $10089 w$ & $\begin{array}{l}\text { SR } \\
\text { Column } \\
\text { Bottom }\end{array}$ & & $\begin{array}{c}3 / \\
13 \\
1\end{array}$ \\
\hline (312) & Set & & $107^{\prime}-11^{\prime \prime}$ & Sixpar $10089 w$ & $\begin{array}{l}\text { SR } \\
\text { Column } \\
\text { Top }\end{array}$ & & $\begin{array}{c}31 \\
11 \\
1\end{array}$ \\
\hline (313) & $\begin{array}{l}\text { 2B Elec } \\
\text { LS\# } 21\end{array}$ & 13 & $-15^{\prime}-11^{\prime \prime}$ & $\begin{array}{l}\text { Sixpar } 100+7.5 " \text { Tophat } \\
89 \mathrm{w}\end{array}$ & $\begin{array}{l}\text { SR } \\
\text { Column } \\
\text { Back }\end{array}$ & & $\begin{array}{c}2 / \\
44 \\
1\end{array}$ \\
\hline (321) & Set & & 116'-5" & Sixpar $10089 w$ & $\begin{array}{l}\text { SL } \\
\text { Column } \\
\text { Bottom }\end{array}$ & & $\begin{array}{c}31 \\
12 \\
1\end{array}$ \\
\hline (322) & Set & & $116^{\prime}-8^{\prime \prime}$ & Sixpar $10089 w$ & $\begin{array}{l}\text { SL } \\
\text { Column } \\
\text { Top }\end{array}$ & & $\begin{array}{c}3 / \\
10 \\
1\end{array}$ \\
\hline (323) & $\begin{array}{l}\text { 2B Elec } \\
\text { LS\# } 21\end{array}$ & 6 & $16^{\prime}-1 "$ & $\begin{array}{l}\text { Sixpar } 100+7.5 " \text { Tophat } \\
89 \mathrm{w}\end{array}$ & $\begin{array}{l}\text { SL } \\
\text { Column } \\
\text { Back }\end{array}$ & & $\begin{array}{c}21 \\
41 \\
6\end{array}$ \\
\hline (331) & $\begin{array}{l}\text { 1C Elec } \\
\text { LS\# } 8\end{array}$ & 8 & $0^{\prime}$ & $\begin{array}{l}\text { Etc Source } 4 \text { LED } 36^{\circ} \\
140 w\end{array}$ & $\begin{array}{l}\text { Steps } \\
\text { Top/Back }\end{array}$ & R132 & $\begin{array}{l}21 \\
461\end{array}$ \\
\hline (341) & $\begin{array}{l}\text { 1B Elec } \\
\text { LS\# } 5\end{array}$ & $3 a$ & $0^{\prime}$ & $\begin{array}{l}\text { Sixpar } 100+7.5 \text { " Tophat } \\
89 \mathrm{w}\end{array}$ & CSUV & & $\begin{array}{r}21 \\
495\end{array}$ \\
\hline (342) & $\begin{array}{l}\text { 1B Elec } \\
\text { LS\# } 5\end{array}$ & $4 a$ & $0^{\prime}$ & $\begin{array}{l}\text { Sixpar } 100+7.5 " \text { Tophat } \\
89 \mathrm{w}\end{array}$ & CSUV & & $\begin{array}{l}21 \\
503\end{array}$ \\
\hline (351) & $\begin{array}{l}\text { 1st } \\
\text { Electric US }\end{array}$ & 22 & $-11^{\prime}-6 "$ & $\begin{array}{l}\text { ETC Source4 50deg } \\
750750 w\end{array}$ & $\begin{array}{l}\text { SR Door } \\
\text { Color }\end{array}$ & R08 & $\begin{array}{c}1 / \\
116\end{array}$ \\
\hline (352) & $\begin{array}{l}\text { 1st } \\
\text { Electric US }\end{array}$ & 17 & $-3 '-6 "$ & $\begin{array}{l}\text { ETC Source4 50deg } \\
750750 w\end{array}$ & $\begin{array}{l}\text { Center } \\
\text { Door Color }\end{array}$ & R08 & $\begin{array}{c}1 / \\
102\end{array}$ \\
\hline (353) & $\begin{array}{l}\text { 1st } \\
\text { Electric US }\end{array}$ & 12 & 4'-6" & $\begin{array}{l}\text { ETC Source4 50deg } \\
750750 w\end{array}$ & $\begin{array}{l}\text { SL Door } \\
\text { Color }\end{array}$ & R08 & $\begin{array}{c}1 / \\
103\end{array}$ \\
\hline (361) & $\begin{array}{l}\text { 1st } \\
\text { Electric US }\end{array}$ & 18 & $-4^{\prime}-6^{\prime \prime}$ & $\begin{array}{l}\text { ETC Source4 50deg } \\
750750 w\end{array}$ & $\begin{array}{l}\text { SR Door } \\
\text { Texture }\end{array}$ & $\begin{array}{l}\text { L201, } \\
\text { T:G368 }\end{array}$ & $\begin{array}{c}1 / \\
104\end{array}$ \\
\hline
\end{tabular}


The Magic Flute load in.Iw6

\begin{tabular}{|c|c|c|c|c|c|c|c|}
\hline Channel & Position & U\# & XCoord & Type \& Acc \& Load & Purp & Clr \& Gbo & $\mathrm{Ad}$ \\
\hline (362) & $\begin{array}{l}\text { 1st } \\
\text { Electric US }\end{array}$ & 13 & 3'-6" & $\begin{array}{l}\text { ETC Source4 50deg } \\
750750 w\end{array}$ & $\begin{array}{l}\text { Center } \\
\text { Door } \\
\text { Texture }\end{array}$ & $\begin{array}{l}\text { O201, } \\
\text { T:G368 }\end{array}$ & $\begin{array}{l}1 / \\
99\end{array}$ \\
\hline (363) & $\begin{array}{l}\text { 1st } \\
\text { Electric US }\end{array}$ & 8 & $11^{\prime}-6^{\prime \prime}$ & $\begin{array}{l}\text { ETC Source4 50deg } \\
750750 \mathrm{w}\end{array}$ & $\begin{array}{l}\text { SL Door } \\
\text { Texture }\end{array}$ & $\begin{array}{l}\text { L201, } \\
\text { T:G368 }\end{array}$ & $\begin{array}{c}1 / \\
115\end{array}$ \\
\hline (371) & $\begin{array}{l}\text { 2nd } \\
\text { Electric DS }\end{array}$ & 8 & 0'-6" & $\begin{array}{l}\text { ETC Source4 50deg } \\
750+6.25 " \text { Tophat } 750 \mathrm{w}\end{array}$ & $\begin{array}{l}\text { Center } \\
\text { Door Back }\end{array}$ & $\mathrm{N} / \mathrm{C}$ & $\begin{array}{c}1 / \\
141\end{array}$ \\
\hline (380) & House & & $0^{\prime}$ & & $\begin{array}{l}\text { House } \\
\text { aisles }\end{array}$ & & $\begin{array}{c}1 / \\
272\end{array}$ \\
\hline (381) & SR Port & 4 & $-33^{\prime}$ & Source 4 19deg $575 w$ & Aisle & TBD & $\begin{array}{l}1 / \\
20\end{array}$ \\
\hline (382) & SR Port & 2 & $-32^{\prime}-11^{\prime \prime}$ & Source 4 19deg $575 w$ & Aisle & TBD & $\begin{array}{l}1 / \\
22 \\
\end{array}$ \\
\hline (383) & SL Port & 4 & $33^{\prime}$ & Source 4 19deg 575w & Aisle & TBD & $\begin{array}{l}1 / \\
23 \\
\end{array}$ \\
\hline (384) & SL Port & 2 & $32^{\prime}-11^{\prime \prime}$ & Source 4 19deg $575 w$ & Aisle & TBD & $\begin{array}{l}1 / \\
19 \\
\end{array}$ \\
\hline (401) & Set & & 6'-1" & LED Tape RGBW & $\begin{array}{l}\text { led tape } \\
\text { step } 1\end{array}$ & & $\begin{array}{c}3 / \\
1\end{array}$ \\
\hline (402) & Set & & 5'-9" & LED Tape RGBW & $\begin{array}{l}\text { led } \\
\text { step } 2\end{array}$ & & $\begin{array}{l}3 / \\
5\end{array}$ \\
\hline (403) & Set & & $5 '-4 "$ & LED Tape RGBW & $\begin{array}{l}\text { led } \\
\text { step } 3\end{array}$ & & $\begin{array}{l}3 / \\
9\end{array}$ \\
\hline (404) & Set & & 4'-11" & LED Tape RGBW & $\begin{array}{l}\text { led } \\
\text { step } 4 \\
\end{array}$ & & $\begin{array}{l}3 / \\
13 \\
\end{array}$ \\
\hline (411) & Set & & $-5^{\prime}-5^{\prime \prime}$ & LED Tape RGBW & $\begin{array}{l}\text { led tape } \\
\text { platform } \\
\text { SR }\end{array}$ & & $\begin{array}{l}3 / \\
17\end{array}$ \\
\hline (412) & Set & & 4'-6" & LED Tape RGBW & $\begin{array}{l}\text { led tape } \\
\text { platform } \\
\text { SL } \\
\end{array}$ & & $\begin{array}{l}3 / \\
21\end{array}$ \\
\hline (451) & LS\# 30 & & $-4^{\prime}-6^{\prime \prime}$ & $\begin{array}{l}\text { ROSEBRAND SHOWLED } \\
\text { STAR DROP }\end{array}$ & $\begin{array}{l}\text { SR STAR } \\
\text { DROP }\end{array}$ & & $\begin{array}{r}3 / \\
351\end{array}$ \\
\hline (452) & LS\# 30 & & 4'-7" & $\begin{array}{l}\text { ROSEBRAND SHOWLED } \\
\text { STAR DROP }\end{array}$ & $\begin{array}{l}\text { SR STAR } \\
\text { DROP }\end{array}$ & & $\begin{array}{c}3 / \\
352\end{array}$ \\
\hline
\end{tabular}


The Magic Flute load in.Iw6

\begin{tabular}{|c|c|c|c|c|c|c|c|}
\hline Channel & Position & U\# & XCoord & Type \& Acc \& Load & Purp & Clr \& Gbo & $\mathrm{Ad}$ \\
\hline (453) & LS\# 30 & & $0^{\prime}$ & $\begin{array}{l}\text { ROSEBRAND SHOWLED } \\
\text { STAR DROP }\end{array}$ & $\begin{array}{l}\text { SR STAR } \\
\text { DROP }\end{array}$ & & $\begin{array}{l}3 / \\
353\end{array}$ \\
\hline (454) & LS\# 30 & & $0^{\prime}$ & $\begin{array}{l}\text { ROSEBRAND SHOWLED } \\
\text { STAR DROP }\end{array}$ & $\begin{array}{l}\text { SRSTAR } \\
\text { DROP }\end{array}$ & & $\begin{array}{c}31 \\
354\end{array}$ \\
\hline (455) & LS\# 30 & & $0^{\prime}$ & $\begin{array}{l}\text { ROSEBRAND SHOWLED } \\
\text { STAR DROP }\end{array}$ & $\begin{array}{l}\text { SR STAR } \\
\text { DROP }\end{array}$ & & $\begin{array}{r}3 / \\
355\end{array}$ \\
\hline (456) & LS\# 30 & & $0^{\prime}$ & $\begin{array}{l}\text { ROSEBRAND SHOWLED } \\
\text { STAR DROP }\end{array}$ & $\begin{array}{l}\text { SR STAR } \\
\text { DROP }\end{array}$ & & $\begin{array}{c}31 \\
356\end{array}$ \\
\hline (457) & LS\# 30 & & $0^{\prime}$ & $\begin{array}{l}\text { ROSEBRAND SHOWLED } \\
\text { STAR DROP }\end{array}$ & $\begin{array}{l}\text { SRSTAR } \\
\text { DROP }\end{array}$ & & $\begin{array}{r}31 \\
357\end{array}$ \\
\hline (458) & LS\# 30 & & $0^{\prime}$ & $\begin{array}{l}\text { ROSEBRAND SHOWLED } \\
\text { STAR DROP }\end{array}$ & $\begin{array}{l}\text { SR STAR } \\
\text { DROP }\end{array}$ & & $\begin{array}{r}3 / \\
358\end{array}$ \\
\hline (461) & LS\# 30 & & $0^{\prime}$ & $\begin{array}{l}\text { ROSEBRAND SHOWLED } \\
\text { STAR DROP }\end{array}$ & $\begin{array}{l}\text { SL STAR } \\
\text { DROP }\end{array}$ & & $\begin{array}{c}3 / \\
301\end{array}$ \\
\hline (462) & LS\# 30 & & $0^{\prime}$ & $\begin{array}{l}\text { ROSEBRAND SHOWLED } \\
\text { STAR DROP }\end{array}$ & $\begin{array}{l}\text { SL STAR } \\
\text { DROP }\end{array}$ & & $\begin{array}{c}31 \\
302\end{array}$ \\
\hline (463) & LS\# 30 & & $0^{\prime}$ & $\begin{array}{l}\text { ROSEBRAND SHOWLED } \\
\text { STAR DROP }\end{array}$ & $\begin{array}{l}\text { SL STAR } \\
\text { DROP }\end{array}$ & & $\begin{array}{c}3 / \\
303\end{array}$ \\
\hline (464) & LS\# 30 & & $0^{\prime}$ & $\begin{array}{l}\text { ROSEBRAND SHOWLED } \\
\text { STAR DROP }\end{array}$ & $\begin{array}{l}\text { SLSTAR } \\
\text { DROP }\end{array}$ & & $\begin{array}{r}31 \\
304\end{array}$ \\
\hline (465) & LS\# 30 & & $0^{\prime}$ & $\begin{array}{l}\text { ROSEBRAND SHOWLED } \\
\text { STAR DROP }\end{array}$ & $\begin{array}{l}\text { SL STAR } \\
\text { DROP }\end{array}$ & & $\begin{array}{r}3 / \\
305\end{array}$ \\
\hline (466) & LS\# 30 & & $0^{\prime}$ & $\begin{array}{l}\text { ROSEBRAND SHOWLED } \\
\text { STAR DROP }\end{array}$ & $\begin{array}{l}\text { SL STAR } \\
\text { DROP }\end{array}$ & & $\begin{array}{r}31 \\
306\end{array}$ \\
\hline (467) & LS\# 30 & & $0^{\prime}$ & $\begin{array}{l}\text { ROSEBRAND SHOWLED } \\
\text { STAR DROP }\end{array}$ & $\begin{array}{l}\text { SL STAR } \\
\text { DROP }\end{array}$ & & $\begin{array}{c}31 \\
307\end{array}$ \\
\hline (468) & LS\# 30 & & $0^{\prime}$ & $\begin{array}{l}\text { ROSEBRAND SHOWLED } \\
\text { STAR DROP }\end{array}$ & $\begin{array}{l}\text { SL STAR } \\
\text { DROP }\end{array}$ & & $\begin{array}{r}3 / \\
308\end{array}$ \\
\hline (501) & $\begin{array}{l}\text { 3rd } \\
\text { Electric DS }\end{array}$ & 25 & $-22^{\prime}-10^{\prime \prime}$ & Altman PAR 64 MFL 1 kW & $\begin{array}{l}\text { Act 2 } \\
\text { Finale } \\
\text { Backs }\end{array}$ & R16 & $\begin{array}{l}1 / \\
18 \\
2\end{array}$ \\
\hline \multirow[t]{2}{*}{ (502) } & $\begin{array}{l}\text { 3rd } \\
\text { Electric DS }\end{array}$ & 23 & $-21^{\prime}$ & Altman PAR 64 MFL 1 kW & $\begin{array}{l}\text { Act 2 } \\
\text { Finale } \\
\text { Backs }\end{array}$ & R16 & $\begin{array}{l}1 / \\
17 \\
8\end{array}$ \\
\hline & $"$ & 24 & $-21^{\prime}-11^{\prime \prime}$ & $"$ & $"$ & " & " \\
\hline
\end{tabular}


The Magic Flute

Channel Hookup

Page 17 of 20

$4 / 17 / 19$

The Magic Flute load in.Iw6

\begin{tabular}{|c|c|c|c|c|c|c|c|}
\hline Channel & Position & U\# & XCoord & Type \& Acc \& Load & Purp & Clr \& Gbo & $\mathrm{Ad}$ \\
\hline (504) & $\begin{array}{l}\text { 3rd } \\
\text { Electric DS }\end{array}$ & 21 & $-18^{\prime}-4^{\prime \prime}$ & Altman PAR 64 MFL 1kW & $\begin{array}{l}\text { Act } 2 \\
\text { Finale } \\
\text { Backs }\end{array}$ & R16 & $\begin{array}{c}1 / \\
17 \\
4\end{array}$ \\
\hline (505) & $\begin{array}{l}\text { 3rd } \\
\text { Electric DS }\end{array}$ & 20 & $-17^{\prime}-6 "$ & Altman PAR 64 MFL 1kW & $\begin{array}{l}\text { Act } 2 \\
\text { Finale } \\
\text { Backs } \\
\end{array}$ & R16 & $\begin{array}{c}1 / \\
17 \\
2 \\
\end{array}$ \\
\hline \multirow[t]{2}{*}{ (506) } & $\begin{array}{l}\text { 3rd } \\
\text { Electric DS }\end{array}$ & 18 & $-15^{\prime}-6 "$ & Altman PAR 64 MFL 1kW & $\begin{array}{l}\text { Act } 2 \\
\text { Finale } \\
\text { Backs }\end{array}$ & R16 & $\begin{array}{c}1 / \\
17 \\
6\end{array}$ \\
\hline & $"$ & 19 & $-16^{\prime}-7^{\prime \prime}$ & $"$ & $"$ & $"$ & $"$ \\
\hline (508) & $\begin{array}{l}\text { 3rd } \\
\text { Electric DS }\end{array}$ & 16 & $-12^{\prime}-10^{\prime \prime}$ & Altman PAR 64 MFL 1kW & $\begin{array}{l}\text { Act } 2 \\
\text { Finale } \\
\text { Backs }\end{array}$ & R16 & $\begin{array}{c}1 / \\
16 \\
8\end{array}$ \\
\hline (509) & $\begin{array}{l}\text { 3rd } \\
\text { Electric DS }\end{array}$ & 15 & $-11^{\prime}-7^{\prime \prime}$ & Altman PAR 64 MFL 1kW & $\begin{array}{l}\text { Act } 2 \\
\text { Finale } \\
\text { Backs }\end{array}$ & R16 & $\begin{array}{c}1 / \\
16 \\
6\end{array}$ \\
\hline (510) & $\begin{array}{l}\text { 3rd } \\
\text { Electric DS }\end{array}$ & 12 & $11^{\prime}-7^{\prime \prime}$ & Altman PAR 64 MFL 1kW & $\begin{array}{l}\text { Act } 2 \\
\text { Finale } \\
\text { Backs }\end{array}$ & R16 & $\begin{array}{c}1 / \\
18 \\
1 \\
\end{array}$ \\
\hline (511) & $\begin{array}{l}\text { 3rd } \\
\text { Electric DS }\end{array}$ & 11 & $12^{\prime}-10^{\prime \prime}$ & Altman PAR 64 MFL 1kW & $\begin{array}{l}\text { Act } 2 \\
\text { Finale } \\
\text { Backs }\end{array}$ & R16 & $\begin{array}{c}1 / \\
18 \\
3\end{array}$ \\
\hline \multirow[t]{2}{*}{ (512) } & $\begin{array}{l}\text { 3rd } \\
\text { Electric DS }\end{array}$ & 8 & $16^{\prime}-7^{\prime \prime}$ & Altman PAR 64 MFL 1 kW & $\begin{array}{l}\text { Act } 2 \\
\text { Finale } \\
\text { Backs }\end{array}$ & R16 & $\begin{array}{c}1 / \\
17 \\
5\end{array}$ \\
\hline & $"$ & 9 & $15^{\prime}-6^{\prime \prime}$ & $"$ & $"$ & $"$ & $"$ \\
\hline (514) & $\begin{array}{l}\text { 3rd } \\
\text { Electric DS }\end{array}$ & 7 & $17^{\prime}-6^{\prime \prime}$ & Altman PAR 64 MFL 1kW & $\begin{array}{l}\text { Act } 2 \\
\text { Finale } \\
\text { Backs }\end{array}$ & R16 & $\begin{array}{c}1 / \\
16 \\
5\end{array}$ \\
\hline (515) & $\begin{array}{l}\text { 3rd } \\
\text { Electric DS }\end{array}$ & 6 & $18^{\prime}-4^{\prime \prime}$ & Altman PAR $64 \mathrm{MFL} 1 \mathrm{~kW}$ & $\begin{array}{l}\text { Act } 2 \\
\text { Finale } \\
\text { Backs }\end{array}$ & R16 & $\begin{array}{c}1 / \\
17 \\
7\end{array}$ \\
\hline \multirow[t]{2}{*}{ (516) } & $\begin{array}{l}\text { 3rd } \\
\text { Electric DS }\end{array}$ & 3 & $21^{\prime}-11^{\prime \prime}$ & Altman PAR 64 MFL 1kW & $\begin{array}{l}\text { Act } 2 \\
\text { Finale } \\
\text { Backs }\end{array}$ & R16 & $\begin{array}{c}1 / \\
17 \\
1\end{array}$ \\
\hline & $"$ & 4 & $21^{\prime}$ & $"$ & $"$ & $"$ & $"$ \\
\hline (518) & $\begin{array}{l}\text { 3rd } \\
\text { Electric DS }\end{array}$ & 2 & $22^{\prime}-10^{\prime \prime}$ & Altman PAR 64 MFL 1kW & $\begin{array}{l}\text { Act } 2 \\
\text { Finale } \\
\text { Backs }\end{array}$ & R16 & $\begin{array}{c}1 / \\
16 \\
7\end{array}$ \\
\hline \multirow[t]{2}{*}{ (551) } & $\begin{array}{l}\text { 3rd } \\
\text { Electric DS }\end{array}$ & 13 & $6^{\prime}$ & Altman PAR 64 NSP $1 \mathrm{~kW}$ & $\begin{array}{l}\text { Sarastro } \\
\text { enters }\end{array}$ & R16 & $\begin{array}{c}1 / \\
161\end{array}$ \\
\hline & $"$ & 14 & $-6^{\prime}$ & $"$ & $"$ & $"$ & $"$ \\
\hline
\end{tabular}


The Magic Flute

Channel Hookup

Page 18 of 20

$4 / 17 / 19$

The Magic Flute load in.Iw6

\begin{tabular}{|c|c|c|c|c|c|c|c|}
\hline Channel & Position & U\# & XCoord & Type \& Acc \& Load & Purp & Clr \& Gbo & $\mathrm{Ad}$ \\
\hline (651) & $\begin{array}{l}\text { FOH 3rd } \\
\text { Beam }\end{array}$ & 18 & $-2^{\prime}-5^{\prime \prime}$ & Source 45 deg $575 w$ & $\begin{array}{l}\mathrm{FOH} \\
\mathrm{CYA}\end{array}$ & TBD & $\begin{array}{l}1 / \\
87\end{array}$ \\
\hline (652) & $\begin{array}{l}\text { FOH 3rd } \\
\text { Beam }\end{array}$ & 1 & 4'-11" & Source 45 deg $575 w$ & $\begin{array}{l}\mathrm{FOH} \\
\mathrm{CYA}\end{array}$ & TBD & $\begin{array}{l}1 / \\
82\end{array}$ \\
\hline (653) & $\begin{array}{l}\text { FOH 3rd } \\
\text { Beam }\end{array}$ & 9 & $22^{\prime}-8^{\prime \prime}$ & Source 410 deg $750 w$ & $\begin{array}{l}\mathrm{FOH} \\
\mathrm{CYA}\end{array}$ & TBD & $\begin{array}{l}1 / \\
75\end{array}$ \\
\hline (654) & $\begin{array}{l}\text { FOH 3rd } \\
\text { Beam }\end{array}$ & 8 & 23'-8" & Source 410 deg $750 w$ & $\begin{array}{l}\mathrm{FOH} \\
\mathrm{CYA}\end{array}$ & TBD & $\begin{array}{l}1 / \\
77\end{array}$ \\
\hline (655) & $\begin{array}{l}\text { FOH 2nd } \\
\text { Beam }\end{array}$ & & $24 '-8 "$ & Source 4 10deg $750 w$ & $\begin{array}{l}\mathrm{FOH} \\
\mathrm{CYA}\end{array}$ & TBD & $\begin{array}{l}1 / \\
69\end{array}$ \\
\hline (656) & $\begin{array}{l}\text { FOH 2nd } \\
\text { Beam }\end{array}$ & & $25^{\prime}-8^{\prime \prime}$ & Source 410 deg $750 w$ & $\begin{array}{l}\mathrm{FOH} \\
\mathrm{CYA}\end{array}$ & TBD & $\begin{array}{l}1 / \\
71\end{array}$ \\
\hline (801) & $\begin{array}{l}\text { 1B Elec } \\
\text { LS\# } 5\end{array}$ & 12 & $-12^{\prime}$ & $\begin{array}{l}\text { Clay Paky Alpha Spot } \\
700 \text { 1.2kW }\end{array}$ & $\begin{array}{l}\text { Mover } \\
1 / 4 \text { UR }\end{array}$ & CYM & $\begin{array}{r}21 \\
251\end{array}$ \\
\hline (802) & $\begin{array}{l}\text { 1B Elec } \\
\text { LS\# } 5\end{array}$ & 4 & $12^{\prime}$ & $\begin{array}{l}\text { Clay Paky Alpha Spot } \\
700 \text { 1.2kW }\end{array}$ & $\begin{array}{l}\text { Mover } \\
1 / 4 \text { UL }\end{array}$ & CYM & $\begin{array}{l}21 \\
111\end{array}$ \\
\hline (811) & $\begin{array}{l}\text { 1B Elec } \\
\text { LS\# } 5\end{array}$ & 8 & $0^{\prime}$ & $\begin{array}{l}\text { High End ShapeShifter } \\
\text { W1 700w }\end{array}$ & $\begin{array}{l}\text { Mover } \\
\text { DSC }\end{array}$ & $\begin{array}{l}\text { LED W+ } \\
\text { UV }\end{array}$ & $\begin{array}{c}21 \\
161\end{array}$ \\
\hline (815) & $\begin{array}{l}\text { 3A Elec } \\
\text { LS\# } 31\end{array}$ & 1 & $0^{\prime}$ & $\begin{array}{l}\text { High End ShapeShifter } \\
\text { C1 700w }\end{array}$ & $\begin{array}{l}\text { Mover } \\
\text { USC/ } \\
\text { Queen } \\
\text { Enters }\end{array}$ & $\begin{array}{l}\text { LED } \\
\text { RGB +UV }\end{array}$ & $\begin{array}{c}3 / \\
40 \\
1\end{array}$ \\
\hline \multirow[t]{2}{*}{ (901) } & $\begin{array}{l}\text { FOH 1st } \\
\text { Beam }\end{array}$ & 1 & 2'-10" & Source 4 19deg $575 \mathrm{w}$ & $\begin{array}{l}\text { Conducto } \\
\text { r Special }\end{array}$ & $\mathrm{N} / \mathrm{C}$ & $\begin{array}{l}1 / \\
6\end{array}$ \\
\hline & $"$ & 2 & $-3^{\prime}-8^{\prime \prime}$ & $"$ & $"$ & $"$ & $\begin{array}{l}1 / \\
3\end{array}$ \\
\hline (951) & Deck & & $-31 '-11^{\prime \prime}$ & Radience Hazer & $\begin{array}{l}\text { SR } \\
\text { Hazer }\end{array}$ & & $\begin{array}{l}4 / \\
39\end{array}$ \\
\hline (952) & Deck & & $31^{\prime}-11^{\prime \prime}$ & Radience Hazer & $\begin{array}{l}\text { SL } \\
\text { Hazer }\end{array}$ & & $\begin{array}{l}4 / \\
466\end{array}$ \\
\hline \multirow[t]{2}{*}{ (990) } & $\begin{array}{l}\text { 1st } \\
\text { Electric DS }\end{array}$ & & $0^{\prime}$ & PAR 64 WFL & $\begin{array}{l}\text { DS } \\
\text { WORKS }\end{array}$ & & $\begin{array}{c}1 / \\
105\end{array}$ \\
\hline & $"$ & & " & $"$ & $"$ & & $\begin{array}{l}1 / \\
114\end{array}$ \\
\hline
\end{tabular}

Justin Burns / Lightwright 6

(651) thru (990) 
The Magic Flute

Channel Hookup

Page 19 of 20

$4 / 17 / 19$

The Magic Flute load in.Iw6

\begin{tabular}{|c|c|c|c|c|c|c|c|}
\hline Channel & Position & U\# & XCoord & Type \& Acc \& Load & Purp & Clr \& Gbo & $\mathrm{Ad}$ \\
\hline \multirow[t]{3}{*}{ (991) } & $\begin{array}{l}\text { 3rd } \\
\text { Electric DS }\end{array}$ & & $0^{\prime}$ & PAR 64 WFL & $\begin{array}{l}\text { US } \\
\text { WORKS }\end{array}$ & & $\begin{array}{l}1 / \\
169\end{array}$ \\
\hline & " & & " & $"$ & $"$ & & $\begin{array}{c}1 / \\
164\end{array}$ \\
\hline & $"$ & & $"$ & $"$ & $"$ & & $\begin{array}{c}1 / \\
162\end{array}$ \\
\hline \multirow[t]{4}{*}{ (999) } & SL Port & 1 & $31^{\prime}$ & Source 4 19deg $575 \mathrm{w}$ & $\begin{array}{l}\text { Curtian } \\
\text { Warmer }\end{array}$ & HOUSE & $\begin{array}{l}1 / \\
17\end{array}$ \\
\hline & $"$ & 3 & $31^{\prime}-1 "$ & $"$ & $"$ & $"$ & $\begin{array}{l}1 / \\
21\end{array}$ \\
\hline & SR Port & 1 & $-31^{\prime}$ & $"$ & $\begin{array}{l}\text { Curtain } \\
\text { Warmer }\end{array}$ & $"$ & $\begin{array}{l}1 / \\
24\end{array}$ \\
\hline & $"$ & 3 & $-31^{\prime}-1 "$ & $\cdots$ & $"$ & $"$ & $\begin{array}{l}1 / \\
18 \\
\end{array}$ \\
\hline \multirow[t]{7}{*}{$(1000)$} & House & & $0^{\prime}$ & & House & & $\begin{array}{c}1 / \\
279\end{array}$ \\
\hline & $"$ & & $"$ & & $"$ & & $\begin{array}{c}1 / \\
278\end{array}$ \\
\hline & $"$ & & $"$ & & $"$ & & $\begin{array}{c}11 \\
277\end{array}$ \\
\hline & ". & & " & & $"$ & & $\begin{array}{c}1 / \\
1 / \\
276\end{array}$ \\
\hline & $"$ & & $"$ & & $"$ & & $\begin{array}{c}1 / \\
275\end{array}$ \\
\hline & $"$ & & $"$ & & $"$ & & $\begin{array}{c}1 / \\
274\end{array}$ \\
\hline & $\cdots$ & & " & & $\cdots "$ & & $\begin{array}{l}1 / 1 \\
1 / 3 \\
273\end{array}$ \\
\hline
\end{tabular}


The Magic Flute

\section{Channel Hookup}

Page 20 of 20

$4 / 17 / 19$

The Magic Flute load in.Iw6

LETTERED Channel

\begin{tabular}{cccc:ccc|c}
\hline Channel & Position & U\# & XCoord & Type \& Acc \& Load & Purp & Clr \& Gbo & Ad \\
\hline (Na) & $\begin{array}{l}\text { Back of } \\
\text { House Spot } \\
\text { Booth }\end{array}$ & 1 & $66^{\prime}-6 "$ & $\begin{array}{l}\text { Strong Xenon Super Trouper } \\
\text { (Long Throw) 1.6kW }\end{array}$ & $\begin{array}{l}\text { Follows } \\
\text { pot }\end{array}$ & & \\
" & 2 & $0^{\prime}$ & " & " & " \\
\hline
\end{tabular}




\section{Appendix 5: Cue Sheet}

LD: Justin Burns

Creative Arts Center: Clay Theatre

West Virginia University
The Magic Flute

\begin{tabular}{|c|c|c|c|c|c|c|c|c|c|c|}
\hline Cue \# & $\begin{array}{c}\text { Music \# } \\
\text { (vid eo) }\end{array}$ & $\begin{array}{c}\text { Page } \\
\#\end{array}$ & $\begin{array}{c}\text { Line/Action } \\
\text { (Measure/Beat) }\end{array}$ & Time & Pick Up & Frame & Iris & Int. & Fade & Description \\
\hline 1 & & 3 & 5 to house open & 3 & & & & & & House Preset \\
\hline 2 & & & SM call & 3 & & & & & & House to half \\
\hline 3 & & & end of curtain speech & 3 & & & & & & BO \\
\hline 5 & 0 & & $1 / 1$ & 15 & & & & & & start overture video lighting \\
\hline 6 & & & $3 / 4$ & 10 & & & & & & \\
\hline 7 & & & allegro & 3 & & & & & & \\
\hline 8 & & 4 & $15 /$ & 3 & & & & & & \\
\hline 9 & & 5 & $31 / 3$ & 3 & & & & & & \\
\hline 10 & & 6 & allegro & 8 & & & & & & \\
\hline 11 & & & piano & 10 & & & & & & \\
\hline 12 & & 7 & forte & 3 & & & & & & \\
\hline 13 & & 9 & 13 & 6 & & & & & & \\
\hline 14 & & & $f f$ & 3 & & & & & & \\
\hline 15 & & & end of overture & 3 & & & & & & blackout? \\
\hline 16 & 1 & 10 & $1 / 1$ & 3 & & & & & & fog and scary, rough and rocky \\
\hline 17 & & 10 & Tam "O help" & 3 & & & & & & add light DSL wing \\
\hline spot 1 & & & $w / 17$ & 3 & Tamino & 3 & $1 / 2$ & & & \\
\hline 18 & & 11 & Ladies enter & 3 & & & & & & mover on Tam SL, and snake SR \\
\hline spot 1 & & & w/ 18 & 3 & 1st lady & 2 & $1 / 2$ & & & \\
\hline spot 2 & & & $w / 18$ & 3 & 2nd lady & 2 & $1 / 2$ & & & \\
\hline spot 3 & & & $w / 18$ & 3 & 3rd lady & 2 & $1 / 2$ & & & \\
\hline 19 & & 13 & & 3 & & & & & & expand ds \\
\hline 20 & & 14 & & 3 & & & & & & dsr and dsl \\
\hline 21 & & 15 & & 3 & & & & & & ds all \\
\hline
\end{tabular}

SPOT FRAMES: R33/R51/R55/R03/L201/R359 


\begin{tabular}{|c|c|c|c|c|c|c|c|c|c|c|}
\hline Cue \# & \begin{tabular}{|c|} 
Music \# \\
(video)
\end{tabular} & $\begin{array}{c}\text { Page } \\
\#\end{array}$ & $\begin{array}{c}\text { Line/Action } \\
\text { (Measure/Beat) }\end{array}$ & Time & Pick Up & Frame & Iris & Int. & Fade & Description \\
\hline 22 & & 16 & & 3 & & & & & & \\
\hline 23 & & & & 3 & & & & & & $x$ to $s r$ \\
\hline 24 & & 17 & & 3 & & & & & & \\
\hline 25 & & 19 & & 3 & & & & & & \\
\hline 26 & & 21 & & 3 & & & & & & \\
\hline 27 & & & end of song & 3 & & & & & & \\
\hline $\begin{array}{c}\text { Spot } \\
1\end{array}$ & & & $w / 27$ & 3 & & & & Out & & \\
\hline $\begin{array}{c}\text { Spot } \\
2\end{array}$ & & & $w / 27$ & 3 & & & & Out & & \\
\hline $\begin{array}{c}\text { Spot } \\
3\end{array}$ & & & $w / 27$ & 3 & & & & Out & & \\
\hline \begin{tabular}{|c|} 
Spot \\
2
\end{tabular} & & & waking up & 3 & Tamino & & & $1 / 2$ & & \\
\hline 28 & & 22 & & 3 & & & & & & \\
\hline \begin{tabular}{|c|} 
Spot \\
1
\end{tabular} & & & $w / 28$ & 3 & Papageno & 4 & & full & & \\
\hline 29 & & & & 3 & & & & & & \\
\hline 30 & & & & 3 & & & & & & \\
\hline 31 & scene & 23 & & 3 & & & & & & \\
\hline spot 1 & & & & 3 & & & & $1 / 2$ & & \\
\hline 32 & & 24 & & 3 & & & & & & \\
\hline 33 & & & & 3 & & & & & & \\
\hline 34 & & 25 & & 3 & & & & & & \\
\hline 35 & 3 & & & 25 & & & & & & \\
\hline spot 1 & & & & 3 & PG & & & out & & \\
\hline spot 2 & & & & 3 & $\mathrm{Tm}$ & 2 & & full & & \\
\hline 36 & & 26 & & 6 & & & & & & \\
\hline 37 & scene & 27 & & 3 & & & & & & restore \\
\hline
\end{tabular}




\begin{tabular}{|c|c|c|c|c|c|c|c|c|c|c|}
\hline Cue \# & $\begin{array}{c}\text { Music \# } \\
\text { (video) }\end{array}$ & $\begin{array}{c}\text { Page } \\
\#\end{array}$ & $\begin{array}{c}\text { Line/Action } \\
\text { (Measure/Beat) }\end{array}$ & Time & Pick Up & Frame & Iris & Int. & Fade & Description \\
\hline 38 & & 28 & c & 0 & & & & & & \\
\hline $\mid 38.3$ & & & D & 0 & & & & & & \\
\hline 38.5 & & & E & 0 & & & & & & \\
\hline 38.7 & & & $\mathrm{~F}$ & 0 & & & & & & \\
\hline 39 & 4 & & G & 0 & & & & & & LAST \\
\hline spot 2 & & & $w / 39$ & 0 & & & & out & & \\
\hline spot 1 & & & queen visible & 0 & Queen & 1 & full & full & & \\
\hline 40 & & & & 3 & & & & & & SCREEN IN \\
\hline 41 & & 30 & & 3 & & & & & & \\
\hline 42 & & 31 & & 3 & & & & & & \\
\hline 43 & & 32 & & 3 & & & & & & \\
\hline 44 & & & & 5 & & & & & & \\
\hline spot 1 & & & $W / 44$ & 3 & & & & out & & \\
\hline 45 & 5 & 33 & & 5 & & & & & & queen colors \\
\hline spot 1 & & & $w / 45$ & 3 & TM & 2 & full & & & \\
\hline spot 2| & & & $w / 45$ & 3 & PG & 2 & full & & & \\
\hline 46 & & 34 & & 3 & & & & & & \\
\hline spot 3 & & & $w / 46$ & 3 & 3 ladies & 3 & trio & & & \\
\hline 47 & & 35 & & 0 & & & & & & \\
\hline 48 & & 37 & & 4 & & & & & & \\
\hline 49 & & 39 & & 3 & & & & & & \\
\hline 50 & & 40 & & 3 & & & & & & \\
\hline 51 & & 42 & & 3 & & & & & & \\
\hline 52 & & 43 & & 3 & & & & & & \\
\hline
\end{tabular}




\begin{tabular}{|c|c|c|c|c|c|c|c|c|c|c|}
\hline Cue \# & $\begin{array}{c}\text { Music \# } \\
\text { (vid eo) }\end{array}$ & $\begin{array}{c}\text { Page } \\
\#\end{array}$ & $\begin{array}{c}\text { Line/Action } \\
\text { (Measure/Beat) }\end{array}$ & Time & Pick Up & Frame & Iris & Int. & Fade & Description \\
\hline 53 & & 44 & & 3 & & & & & & \\
\hline \begin{tabular}{|c|} 
Spot \\
1
\end{tabular} & & & & 3 & & & $1 / 2$ & & & \\
\hline \begin{tabular}{|c|} 
Spot \\
2
\end{tabular} & & & & 3 & & & $1 / 2$ & & & \\
\hline 54 & & 46 & & 6 & & & & & & \\
\hline \begin{tabular}{|c|} 
Spot \\
1
\end{tabular} & & & & 3 & & & & out & & \\
\hline \begin{tabular}{|c|} 
Spot \\
2
\end{tabular} & & & & 3 & & & & Out & & \\
\hline \begin{tabular}{|c|} 
Spot \\
3
\end{tabular} & & & & 3 & & & & Out & & \\
\hline 55 & SCENE & & OFFSTAGE LAUGHTER & 1 & & & & & & \\
\hline 56 & & & & 3 & & & & & & \\
\hline 57 & & 47 & & 3 & & & & & & \\
\hline \begin{tabular}{|c|} 
Spot \\
1
\end{tabular} & & & $w / 57$ & 3 & Mono & 5 & & & & \\
\hline \begin{tabular}{|c|} 
Spot \\
2
\end{tabular} & & & $w / 57$ & 3 & Pam & 3 & & & & \\
\hline 58 & & & & 3 & & & & & & \\
\hline 59 & & 48 & & 3 & & & & & & \\
\hline Spots & & & & 3 & & & & out & & \\
\hline 60 & & & & 3 & & & & & & \\
\hline spot 3 & & & $w / 60$ & 3 & $\mathrm{pg}$ & 2 & & full & & \\
\hline 61 & & 49 & & 3 & & & & & & \\
\hline spot 1 & & & $w / 61$ & 3 & mono & 2 & & full & & \\
\hline 62 & & & & 3 & & & & & & \\
\hline Spots & & & $w / 62$ & 3 & & & & out & & \\
\hline 63 & & 50 & & 3 & & & & & & \\
\hline spot 1 & & & $w / 63$ & 3 & $\mathrm{pg}$ & 1 & & $1 / 2$ & & \\
\hline spot 2 & & & $w / 63$ & 3 & Pam & 1 & & $1 / 2$ & & \\
\hline
\end{tabular}




\begin{tabular}{|c|c|c|c|c|c|c|c|c|c|c|}
\hline Cue \# & \begin{tabular}{|c|} 
Music \# \\
(vid eo)
\end{tabular} & $\begin{array}{c}\text { Page } \\
\#\end{array}$ & $\begin{array}{c}\text { Line/Action } \\
\text { (Measure/Beat) }\end{array}$ & Time & Pick Up & Frame & Iris & Int. & Fade & Description \\
\hline 64 & 7 & 51 & & 15 & & & & & & \\
\hline Spots & & & $w / 64$ & 3 & & & & full & & \\
\hline 65 & & 52 & & 8 & & & & & & \\
\hline 66 & & 53 & & 10 & & & & & & \\
\hline 67 & & & & 2 & & & & & & \\
\hline spot 1 & & & $w / 67$ & 3 & & & & out & & \\
\hline spot 2 & & & $w / 67$ & 3 & & & & out & & \\
\hline spot 3 & & & tamino enters & 3 & $\mathrm{Tm}$ & 2 & & $1 / 2$ & & \\
\hline 67.5 & 8 & & & 3 & & & & & & \\
\hline 68 & & 55 & & 3 & & & & & & \\
\hline 69 & & 57 & & 1.5 & & & & & & \\
\hline 70 & & & & 1.5 & & & & & & \\
\hline 71 & & & & 3 & & & & & & \\
\hline spot 1 & & & enters & 3 & priest & 2 & full & $1 / 2$ & & \\
\hline 72 & & 61 & & 3 & & & & & & \\
\hline spot 1 & & & exit & 3 & & & out & & & \\
\hline 73 & & & & 3 & & & & & & \\
\hline 74 & & & & 8 & & & & & & \\
\hline 75 & & 62 & & 6 & & & & & & \\
\hline 76 & & & & 3 & & & & & & \\
\hline 77 & & 63 & & 25 & & & & & & DISTANT TEMPLE WITH SPIRITS \\
\hline 78 & & 64 & & 3 & & & & & & \\
\hline 79 & & & & 3 & & & & & & \\
\hline 80 & & & & 3 & & & & & & \\
\hline 81 & & & & 3 & & & & & & \\
\hline
\end{tabular}




\begin{tabular}{|c|c|c|c|c|c|c|c|c|c|c|}
\hline Cue \# & \begin{tabular}{|c|}
$\begin{array}{c}\text { Music \# } \\
\text { (video) }\end{array}$ \\
\end{tabular} & $\begin{array}{c}\text { Page } \\
\#\end{array}$ & $\begin{array}{c}\text { Line/Action } \\
\text { (Measure/Beat) }\end{array}$ & Time & Pick Up & Frame & Iris & Int. & Fade & Description \\
\hline 82 & & & & 3 & & & & & & \\
\hline 83 & & & & 3 & & & & & & \\
\hline 84 & & 65 & & 8 & & & & & & \\
\hline 85 & & & & 6 & & & & & & \\
\hline spot 3 & & & $w / 85$ & 3 & & & & out & & \\
\hline \begin{tabular}{|c|} 
Spot \\
1
\end{tabular} & & 66 & enters & 3 & pam & 1 & & full & & \\
\hline \begin{tabular}{|c|} 
Spot \\
2
\end{tabular} & & & enters & 3 & $\mathrm{pg}$ & 1 & & full & & \\
\hline 86 & & 68 & & 3 & & & & & & \\
\hline spot 3 & & & enters & 3 & mono & 5 & & full & & \\
\hline 87 & & 69 & & 6 & & & & & & \\
\hline 88 & & & & 3 & & & & & & \\
\hline 89 & & 70 & & 0 & & & & & & \\
\hline spot 3 & & & exit & 3 & & & & out & & \\
\hline 90 & & & & 0 & & & & & & \\
\hline 91 & & 71 & & 1 & & & & & & \\
\hline 92 & & 72 & & 6 & & & & & & \\
\hline 93 & & & & 1 & & & & & & \\
\hline 94 & & 73 & & 3 & & & & & & \\
\hline 95 & & & & 3 & & & & & & \\
\hline 96 & & 74 & & 3 & & & & & & \\
\hline spot 3 & & & & 3 & sara & 4 & & full & & \\
\hline 97 & & 75 & & 3 & & & & & & \\
\hline 98 & & 76 & & 3 & & & & & & \\
\hline 99 & & 77 & & 6 & & & & & & \\
\hline 100 & & 78 & & 3 & & & & & & \\
\hline 101 & & 79 & & 6 & & & & & & \\
\hline 102 & & & & 2 & & & & & & \\
\hline
\end{tabular}




\begin{tabular}{|c|c|c|c|c|c|c|c|c|c|c|}
\hline Cue \# & \begin{tabular}{|c|} 
Music \# \\
(video)
\end{tabular} & $\begin{array}{c}\text { Page } \\
\#\end{array}$ & $\begin{array}{c}\text { Line/Action } \\
\text { (Measure/Beat) }\end{array}$ & Time & Pick Up & Frame & Iris & Int. & Fade & Description \\
\hline 103 & & 80 & & 3 & & & & & & \\
\hline 104 & & 81 & & 3 & & & & & & \\
\hline 105 & & & & 4 & & & & & & lose fronts, main rag in \\
\hline spot 1 & & & $\mathrm{w} / 105$ & 3 & & & & out & & \\
\hline \begin{tabular}{|c|} 
Spot \\
2
\end{tabular} & & & $w / 105$ & 3 & & & & out & & \\
\hline spot 3 & & & $w / 105$ & 3 & & & & out & & \\
\hline 106 & INT & & & 0 & & & & & & house up \\
\hline 107 & & 82 & & 3 & & & & & & house to $1 / 2$ \\
\hline 108 & & & & 3 & & & & & & BO \\
\hline 109 & 9 & & & 8 & & & & & & VIDEO DIMENSION \\
\hline 110 & & & & 8 & & & & & & \\
\hline 111 & & & & 5 & & & & & & \\
\hline 112 & & 83 & & 3 & & & & & & \\
\hline 113 & & & & 3 & & & & & & \\
\hline 114 & & & & 3 & & & & & & \\
\hline 115 & & & & 3 & & & & & & \\
\hline 116 & & & & 3 & & & & & & \\
\hline 117 & & & & 3 & & & & & & \\
\hline 118 & & & & 3 & & & & & & \\
\hline 119 & & & & 3 & & & & & & \\
\hline 120 & 10 & & & 15 & & & & & & \\
\hline spot 2 & & & & 3 & sara & 4 & & full & & \\
\hline 121 & & 84 & & 3 & & & & & & \\
\hline 122 & & & & 3 & & & & & & \\
\hline 123 & & & & 3 & & & & & & \\
\hline 124 & 19 & $84-1$ & & 3 & & & & & & \\
\hline \begin{tabular}{|c|} 
Spot \\
1
\end{tabular} & & & $w / 124$ & 3 & pam & 2 & & & & \\
\hline
\end{tabular}




\begin{tabular}{|c|c|c|c|c|c|c|c|c|c|c|}
\hline Cue \# & $\underset{\text { (vid eo) }}{\text { Music \# }}$ & $\begin{array}{c}\text { Page } \\
\#\end{array}$ & $\begin{array}{c}\text { Line/Action } \\
\text { (Measure/Beat) }\end{array}$ & Time & Pick Up & Frame & Iris & Int. & Fade & Description \\
\hline 125 & & $84-2$ & & 3 & & & & & & \\
\hline 126 & & $84-4$ & & 3 & & & & & & \\
\hline 127 & & & & 3 & & & & & & \\
\hline 128 & & $84-5$ & & 3 & & & & & & \\
\hline 129 & scene & & & 3 & & & & & & \\
\hline spot 1 & & & $w / 129$ & 3 & & & & out & & \\
\hline $\begin{array}{c}\text { Spot } \\
2\end{array}$ & & & $w / 129$ & 3 & & & & out & & \\
\hline spot 1 & & & enters & 3 & $\mathrm{pg}$ & 5 & head & $1 / 2$ & & \\
\hline $\begin{array}{c}\text { Spot } \\
2\end{array}$ & & & enters & 3 & $\mathrm{tm}$ & 5 & head & $1 / 2$ & & \\
\hline 130 & & 85 & I & 0 & & & & & & THUNDERS \\
\hline 131 & & & J & 0 & & & & & & \\
\hline 132 & & & K & 0 & & & & & & \\
\hline 133 & & & & 0 & & & & & & \\
\hline 134 & & & & 0 & & & & & & \\
\hline 135 & & & & 0 & & & & & & \\
\hline 136 & 11 & 86 & & 0 & & & & & & \\
\hline spot 1 & & & $w / 136$ & 3 & PG & & & full & & \\
\hline $\begin{array}{c}\text { Spot } \\
2\end{array}$ & & & $w / 136$ & 3 & TM & & & full & & \\
\hline 137 & & & & 3 & & & & & & \\
\hline 138 & & & & 3 & & & & & & \\
\hline 139 & & & & 3 & & & & & & \\
\hline 140 & & & & 3 & & & & & & \\
\hline 141 & 12 & 87 & & 3 & & & & & & QUEEN \\
\hline 142 & & 93 & & 3 & & & & & & \\
\hline 143 & & 95 & & 6 & & & & & & LIGHTNING \\
\hline 144 & & & & 3 & & & & & & \\
\hline 145 & scene & & & 0 & & & & & & STOP \\
\hline 146 & & 96 & & 3 & & & & & & \\
\hline
\end{tabular}




\begin{tabular}{|c|c|c|c|c|c|c|c|c|c|c|}
\hline Cue \# & \begin{tabular}{|c|} 
Music \# \\
(video)
\end{tabular} & $\begin{array}{c}\text { Page } \\
\#\end{array}$ & $\begin{array}{c}\text { Line/Action } \\
\text { (Measure/Beat) }\end{array}$ & Time & Pick Up & Frame & Iris & Int. & Fade & Description \\
\hline \begin{tabular}{|c|} 
Spot \\
2
\end{tabular} & & & & 3 & TM & & & out & & \\
\hline 147 & & & & $12 / 8$ & & & & & & \\
\hline \begin{tabular}{|c|} 
Spot \\
1
\end{tabular} & & & & 3 & PG & & & out & & \\
\hline 148 & 13 & 97 & & 3 & & & & & & \\
\hline spot 3 & & & $w / 148$ & 3 & mono & 5 & & full & & \\
\hline 149 & & 98 & & 3 & & & & & & \\
\hline $\begin{array}{c}\text { Spot } \\
1\end{array}$ & & & $w / 149$ & 3 & queen & 1 & & full & & \\
\hline spot 2 & & & she wakes up & 3 & pam & 1 & & full & & \\
\hline 150 & & 99 & & 3 & & & & & & \\
\hline 151 & & 100 & & 3 & & & & & & \\
\hline 152 & & & & 3 & & & & & & \\
\hline 153 & & 101 & & 10 & & & & & & \\
\hline 154 & & & & 3 & & & & & & \\
\hline 155 & & 102 & & 3 & & & & & & \\
\hline 156 & & & $\mathrm{~N}$ & 0 & & & & & & THUNDERS \\
\hline $\begin{array}{c}\text { Spot } \\
1\end{array}$ & & & EXIT & 3 & & & & out & & \\
\hline spot 2 & & & EXIT & 3 & & & & out & & \\
\hline 157 & SCENE & 103 & SCENE & 3 & & & & & & \\
\hline 158 & & & & 3 & & & & & & \\
\hline 159 & 15 & & & 3 & & & & & & \\
\hline \begin{tabular}{|c|} 
Spot \\
1
\end{tabular} & & & & 3 & sara & 4 & $1 / 2$ & full & & \\
\hline \begin{tabular}{|c|} 
Spot \\
2
\end{tabular} & & & & 3 & pam & 1 & $1 / 2$ & full & & \\
\hline 160 & & 104 & & 3 & & & & & & \\
\hline 161 & scene & & & 4 & & & & & & \\
\hline spot 1 & & & & 3 & & & & out & & \\
\hline \begin{tabular}{|c|} 
Spot \\
2
\end{tabular} & & & & 3 & & & & out & & \\
\hline spot 1 & & & enters & 3 & $\mathrm{tm}$ & 5 & head & $1 / 2$ & & \\
\hline
\end{tabular}




\begin{tabular}{|c|c|c|c|c|c|c|c|c|c|c|}
\hline Cue \# & \begin{tabular}{|c|} 
Music \# \\
(video)
\end{tabular} & $\begin{array}{c}\text { Page } \\
\#\end{array}$ & $\begin{array}{c}\text { Line/Action } \\
\text { (Measure/Beat) }\end{array}$ & Time & Pick Up & Frame & Iris & Int. & Fade & Description \\
\hline \begin{tabular}{|c|} 
Spot \\
2
\end{tabular} & & & enters & 3 & $\mathrm{pg}$ & 5 & head & $1 / 2$ & & \\
\hline 162 & & 105 & & 3 & & & & & & \\
\hline 163 & & & & 3 & & & & & & \\
\hline 164 & & & & 3 & & & & & & \\
\hline 165 & & & & 6 & & & & & & \\
\hline 166 & & & & 0 & & & & & & \\
\hline 167 & 16 & 106 & & 3 & & & & & & \\
\hline spot 1 & & & $w / 167$ & 3 & $\mathrm{tm}$ & & & full & & \\
\hline \begin{tabular}{|c|} 
Spot \\
2
\end{tabular} & & & $w / 167$ & 3 & $\mathrm{pg}$ & & & full & & \\
\hline 168 & & & & 3 & & & & & & \\
\hline 169 & scene & 108 & & 3 & & & & & & \\
\hline 170 & & & & 15 & & & & & & \\
\hline 171 & & & & 3 & & & & & & \\
\hline $\begin{array}{c}\text { Spot } \\
1\end{array}$ & & & $w / 171$ & 3 & $\mathrm{tm}$ & & $1 / 2$ & full & & \\
\hline \begin{tabular}{|c|} 
Spot \\
2
\end{tabular} & & & $w / 171$ & 3 & $\mathrm{pg}$ & & $1 / 2$ & full & & \\
\hline spot 3 & & & $w / 171$ & 3 & pam & 1 & $1 / 2$ & full & & \\
\hline 172 & 17 & & & 30 & & & & & & \\
\hline spot 3 & & & & 3 & pam & & & $1 / 2$ & & \\
\hline 173 & & 110 & & 3 & & & & & & \\
\hline spot 3 & & & $w / 173$ & 3 & pam & & & out & & \\
\hline 174 & & & & 3 & & & & & & \\
\hline 175 & & & $R$ & 3 & & & & & & \\
\hline 176 & & & FLUTE PLAYS & 18 & & & & & & \\
\hline |176.5 & & & & 3 & & & & & & RESTORE \\
\hline 177 & & & & 3 & & & & & & TRUMPETS \\
\hline 178 & 18 & 111 & & 3 & & & & & & \\
\hline 179 & scene & 112 & & 3 & & & & & & \\
\hline
\end{tabular}




\begin{tabular}{|c|c|c|c|c|c|c|c|c|c|c|}
\hline \begin{tabular}{|l|} 
Cue \# \\
\end{tabular} & \begin{tabular}{|c|}
$\begin{array}{c}\text { Music \# } \\
\text { (video) }\end{array}$ \\
\end{tabular} & $\begin{array}{c}\text { Page } \\
\#\end{array}$ & $\begin{array}{c}\text { Line/Action } \\
\text { (Measure/Beat) }\end{array}$ & Time & Pick Up & Frame & Iris & Int. & Fade & Description \\
\hline spot 3 & & & & 3 & sara & 4 & full & full & & \\
\hline 180 & & & & 3 & & & & & & \\
\hline \begin{tabular}{|c|} 
Spot \\
1
\end{tabular} & & & & 3 & & & & Out & & \\
\hline spot 2 & & & & 3 & & & & OUT & & \\
\hline 181 & & 117 & s & 0 & & & & & & CSL WING THUNDER \\
\hline 182 & & & $\mathrm{~T}$ & 0 & & & & & & CSR THUNDER WING \\
\hline 183 & & & & 3 & & & & & & \\
\hline 184 & & & & 3 & & & & & & 3 IN JUDGEMENT PG \\
\hline 185 & 20 & 118 & & 5 & & & & & & \\
\hline spot 2 & & & & 3 & $\mathrm{pg}$ & 1 & $1 / 2$ & full & & \\
\hline 186 & & 119 & & 6 & & & & & & \\
\hline 187 & & 120 & & 6 & & & & & & \\
\hline 188 & & 121 & & 6 & & & & & & \\
\hline 189 & & 122 & & 6 & & & & & & \\
\hline 190 & & & & 6 & & & & & & \\
\hline 191 & & 123 & & 8 & & & & & & \\
\hline 192 & scene & & & $5 / 8$ & & & & & & \\
\hline spot 2 & & & & 3 & $\mathrm{pg}$ & & & out & & \\
\hline 193 & & & & 0 & & & & & & \\
\hline 194 & & & & 4 & & & & & & \\
\hline 195 & & & & 3 & & & & & & \\
\hline 196 & 21 & 124 & & 3 & & & & & & \\
\hline 197 & & 125 & & $4 / 6$ & & & & & & \\
\hline 198 & & 126 & & 3 & & & & & & \\
\hline \begin{tabular}{|c|} 
Spot \\
1
\end{tabular} & & & & 3 & PAM & 2 & $1 / 2$ & Full & & \\
\hline 199 & & 128 & & 3 & & & & & & \\
\hline 200 & & 131 & & 3 & & & & & & \\
\hline
\end{tabular}




\begin{tabular}{|c|c|c|c|c|c|c|c|c|c|c|}
\hline Cue \# & $\begin{array}{c}\text { Music \# } \\
\text { (vid eo) }\end{array}$ & $\begin{array}{c}\text { Page } \\
\#\end{array}$ & $\begin{array}{c}\text { Line/Action } \\
\text { (Measure/Beat) }\end{array}$ & Time & Pick Up & Frame & Iris & Int. & Fade & Description \\
\hline 201 & & 132 & & 3 & & & & & & \\
\hline 202 & & 133 & & 3 & & & & & & \\
\hline $\begin{array}{c}\text { Spot } \\
1\end{array}$ & & & & 3 & & & & Out & & \\
\hline 203 & & 134 & & 3 & & & & & & \\
\hline 204 & & 135 & & 10 & & & & & & \\
\hline \begin{tabular}{|c|} 
Spot \\
2
\end{tabular} & & & & 3 & TAM & 3 & $1 / 2$ & Full & & \\
\hline 205 & & & & 3 & & & & & & \\
\hline 206 & & 136 & & 12 & & & & & & \\
\hline spot 1 & & & & 3 & PAM & 3 & $1 / 2$ & Full & & \\
\hline 207 & & 138 & & 6 & & & & & & \\
\hline 208 & & 140 & & 6 & & & & & & \\
\hline 209 & & 141 & & 6 & & & & & & \\
\hline 210 & & 142 & & 4 & & & & & & \\
\hline 211 & & & & 3 & & & & & & \\
\hline 212 & & 143 & & 3 & & & & & & \\
\hline 213 & & & & 1 & & & & & & \\
\hline 214 & & 144 & & 3 & & & & & & \\
\hline spot 1 & & & & 3 & & & & Out & & \\
\hline $\begin{array}{c}\text { Spot } \\
2\end{array}$ & & & & 3 & & & & Out & & \\
\hline 215 & & 145 & & 3 & & & & & & \\
\hline spot 3 & & & & 3 & PG & 1 & & Full & & \\
\hline 216 & & 148 & & 3 & & & & & & \\
\hline 217 & & 149 & & 3 & & & & & & \\
\hline 218 & & 150 & & 10 & & & & & & \\
\hline 219 & & 151 & & 3 & & & & & & \\
\hline 220 & & 152 & & 3 & & & & & & \\
\hline 221 & & 153 & & 3 & & & & & & \\
\hline
\end{tabular}




\begin{tabular}{|c|c|c|c|c|c|c|c|c|c|c|}
\hline Cue \# & \begin{tabular}{|c|} 
Music \# \\
(vid eo)
\end{tabular} & $\begin{array}{c}\text { Page } \\
\#\end{array}$ & $\begin{array}{c}\text { Line/Action } \\
\text { (Measure/Beat) }\end{array}$ & Time & Pick Up & Frame & Iris & Int. & Fade & Description \\
\hline 222 & & 155 & & 0 & & & & & & \\
\hline spot 1 & & & & 3 & PGA & 1 & & full & & \\
\hline 223 & & 156 & & 3 & & & & & & \\
\hline 224 & & 158 & & 5 & & & & & & \\
\hline 225 & & & & 4.5 & & & & & & \\
\hline 226 & & 160 & & 3 & & & & & & \\
\hline 227 & & 162 & & 3 & & & & & & \\
\hline spot 1 & & & & 3 & & & & out & & \\
\hline \begin{tabular}{|c|} 
Spot \\
2
\end{tabular} & & & & 3 & & & & out & & \\
\hline 228 & & & & 3 & & & & & & \\
\hline 229 & & 162 & & 0 & & & & & & \\
\hline 230 & & 163 & & 3 & & & & & & \\
\hline 230.5 & & 164 & & 3 & & & & & & \\
\hline 231 & & 165 & & 3 & & & & & & \\
\hline 232 & & & & 3 & & & & & & \\
\hline 233 & & 167 & & 2 & & & & & & \\
\hline 234 & & & & 3 & & & & & & BO \\
\hline 235 & & & & 2 & & & & & & Curtain Call \\
\hline 236 & & & & 3 & & & & & & Fronts out, rag in \\
\hline 237 & & & & 3 & & & & & & House up/exit \\
\hline
\end{tabular}




\section{Appendix 6: Final Lighting Budget}

Lighting Budget

THE MAGIC FLUTE

Prepared by:

Justin Burns

\begin{tabular}{|c|c|c|c|}
\hline Item & Description & Vendor & Cost \\
\hline Vincent Rental Package & $\begin{array}{c}36 \text { Elation 6PAR LEDs/Cable } \\
\text { Lot }\end{array}$ & $\begin{array}{c}\text { Vincent Lighting Systems } \\
\text { (Pitt) }\end{array}$ & $\$ 1,760$ \\
\hline LED practicals & $\begin{array}{l}2 \text { BA9 LEDs/wiring supplies for } \\
\text { Monostatos (include spare) }\end{array}$ & Superbrite LEDs/Stock & 19.27 \\
\hline LED Tape/control/PSU & 6 channels; 7 rolls & Superbrite LEDs/Stock & $\$$ \\
\hline Gel & Split gel order with WVPT & $\begin{array}{l}\text { Stock/Vincent Lighting } \\
\text { Systems (Pitt) }\end{array}$ & $\$$ \\
\hline \multirow[t]{2}{*}{ Scenic unit Mounting Hardware } & See Scenic drawings for details & Stock & $\$$ \\
\hline & & TOTAL & $\$ 1,873$ \\
\hline
\end{tabular}

\begin{tabular}{|c|c|}
\hline BUDGET & $\$ 2,000$ \\
\hline SPENT & $\$ 1,873$ \\
\hline REMAINING & $\$ 127$ \\
\hline
\end{tabular}

